ArgOrational laboratory

ANL/ESD/10-3

\title{
Well-to-Wheels Analysis of Landfill Gas-Based Pathways and Their Addition to the GREET Model
}

Energy Systems Division 


\begin{abstract}
About Argonne National Laboratory
Argonne is a U.S. Department of Energy laboratory managed by UChicago Argonne, LLC under contract DE-AC02-06CH11357. The Laboratory's main facility is outside Chicago, at 9700 South Cass Avenue, Argonne, Illinois 60439. For information about Argonne and its pioneering science and technology programs, see www.anl.gov.
\end{abstract}

\title{
Availability of This Report
}

This report is available, at no cost, at http://www.osti.gov/bridge. It is also available on paper to the U.S. Department of Energy and its contractors, for a processing fee, from:

U.S. Department of Energy

Office of Scientific and Technical Information

P.O. Box 62

Oak Ridge, TN 37831-0062

phone (865) 576-8401

fax (865) 576-5728

reports@adonis.osti.gov

\begin{abstract}
Disclaimer
This report was prepared as an account of work sponsored by an agency of the United States Government. Neither the United States Government nor any agency thereof, nor UChicago Argonne, LLC, nor any of their employees or officers, makes any warranty, express or implied, or assumes any legal liability or responsibility for the accuracy, completeness, or usefulness of any information, apparatus, product, or process disclosed, or represents that its use would not infringe privately owned rights. Reference herein to any specific commercial product, process, or service by trade name, trademark, manufacturer, or otherwise, does not necessarily constitute or imply its endorsement, recommendation, or favoring by the United States Government or any agency thereof. The views and opinions of document authors expressed herein do not necessarily state or reflect those of the United States Government or any agency thereof, Argonne National Laboratory, or UChicago Argonne, LLC.
\end{abstract}




\section{Well-to-Wheels Analysis of Landfill Gas-Based Pathways and Their Addition to the GREET Model}

by

M. Mintz, J. Han, M. Wang, and C. Saricks

Center for Transportation Research

Energy Systems Division, Argonne National Laboratory

May 2010 



\section{CONTENTS}

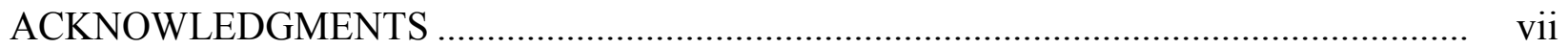

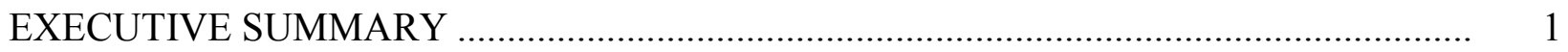

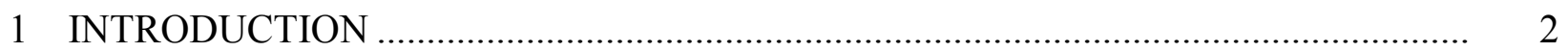

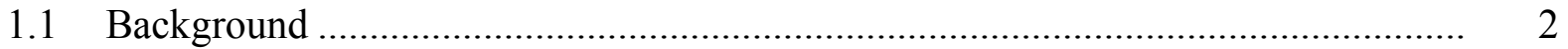

1.2 U.S. Natural Gas Resources ...............................................................................

1.3 Natural Gas as a Vehicle Fuel ................................................................................ 5

1.4 Renewable Natural Gas and GHG Emissions ........................................................... 5

$1.5 \quad$ Fuel Cycle Analysis ............................................................................................. 5

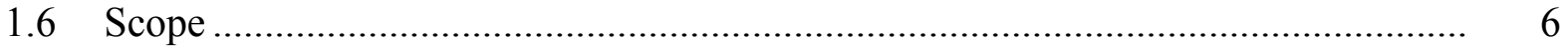

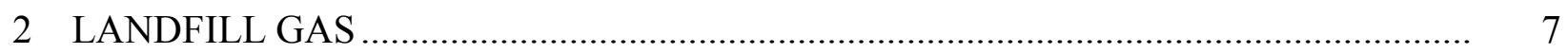

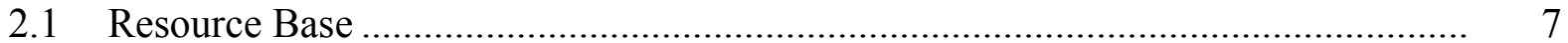

2.2 Resource Development .............................................................................. 10

2.3 Additions to the Resource Base _........................................................................ 10

2.4 Landfill Gas Composition .................................................................................. 11

3 FUEL CYCLE ANALYSIS OF LANDFILL-GAS-BASED PATHWAYS ....................... 13

3.1 LFG Reference Case ........................................................................................ 13

3.1.1 Flaring versus Venting Landfill Gas ........................................................ 13

3.1.2 Carbon Fate in LFG, Fossil NG and Petroleum Fuel Cycles ......................... 15

3.2 Overview of LFG-to-CNG/LNG Fuel Cycle ……….............................................. 17

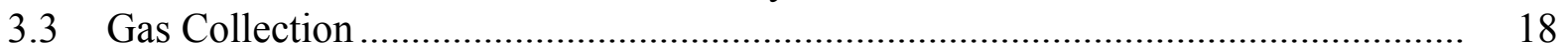

3.4 Natural Gas Production ................................................................................ 18

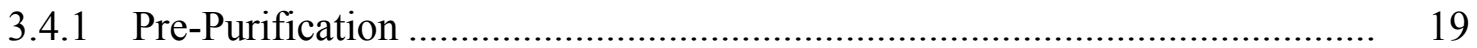

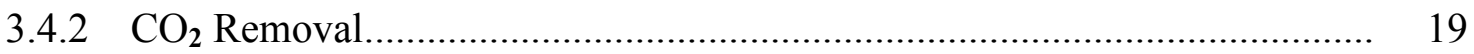

3.4.3 Process Efficiency …………….......................................................... 21

3.4.4 Energy Use Accounting ....................................................................... 22

3.5 On-Site Power Generation ............................................................................. 22

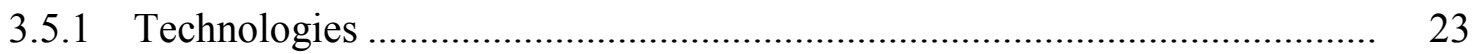

3.5.2 Criteria Pollutant Emissions ...................................................................... 23

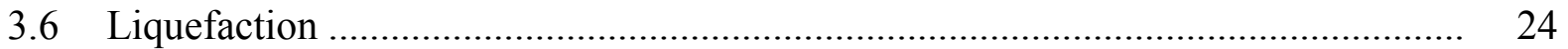

3.7 Transportation and Distribution ..................................................................... 25

3.7.1 Transportation and Distribution of CNG ................................................. 25

3.7.2 Transportation and Distribution of LNG................................................... 26

3.8 Vehicle Operation ................................................................................. 26 


\section{CONTENTS (CONT.)}

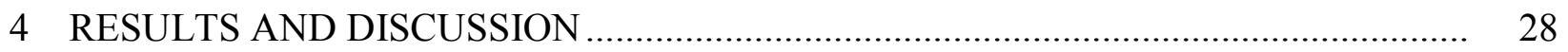

4.1 Energy and Greenhouse Gas Emission Rates ..................................................... 28

4.1.1 WTW Energy ............................................................................ 28

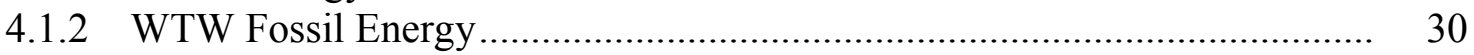

4.1.3 WTW Greenhouse Gas Emissions ...................................................... 32

4.2 Energy and Greenhouse Gas Emissions per Mile Traveled..................................... 34

4.2.1 LFG-Based CNG ............................................................................ 34

4.2.2 LFG-Based LNG ............................................................................ 36

4.3 Balancing Energy Efficiency with Greenhouse Gas Emissions............................... 38

4.4 Co-Product and Renewable Energy Credits ........................................................... 39

4.4.1 Carbon Dioxide .................................................................................. 39

4.4.2 Renewable Energy Credits and Other Incentives......................................... 40

4.5 Criteria Pollutant Emissions .................................................................................. 41

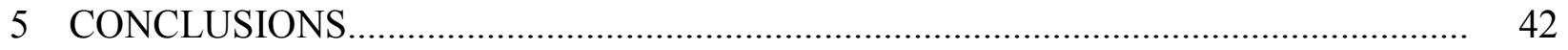

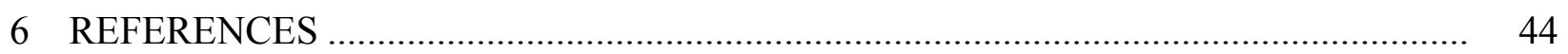

APPENDIX A: SMALL-SCALE NATURAL GAS LIQUEFACTION ................................... 49

APPENDIX B: CRITERIA POLLUTANTS ................................................................. 52

\section{FIGURES}

1 Natural Gas Reserve Additions as Percent of Annual Production, 1997-2007 ............... 3

2 Pipeline Capacity Additions, 1998-2008 ………………………………….................... 4

3 Disposition of Municipal Solid Waste, 1960-2007 ………………............................... 8

$4 \quad$ Typical Landfill Gas Production and Recovery Profile ……………………………......... 9

5 Operational LFG-to-Energy Projects and Candidate Landfills by State ........................... 11

6 Fuel Cycle for Landfill-Gas-Based CNG and LNG, as Used in GREET Modeling......... 14

$7 \quad \mathrm{CO}_{2}$ Equivalent Emissions of Flaring versus Venting Landfill Gas ............................... 15

$8 \quad \mathrm{CO}_{2}$ Emissions in LFG-to-CNG/LNG Fuel Cycle …...................................................... 16 


\section{FIGURES (CONT.)}

$9 \mathrm{CO}_{2}$ Emissions in Fossil NG-to-CNG/LNG Fuel Cycle ………........................................ 16

$10 \mathrm{CO}_{2}$ Emissions in Petroleum Gasoline/Diesel Fuel Cycle ............................................. 16

11 Gas Processing Cost (GPC) Associated with 1-, 2-, and 3-Stage Membranes ................. 20

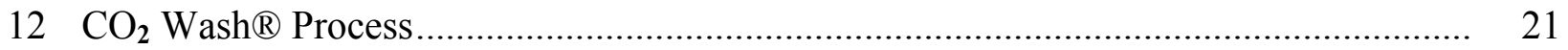

13 NG Processing Efficiencies of LFG-Based Projects Producing Vehicle Fuel .................. 22

14 WTP, PTW, and WTW Energy Use for LFG-to-CNG/LNG Pathways versus Fossil NG-to-CNG/LNG, Gasoline, and Diesel Pathways............................................... 29

15 WTW Fossil Fuel Use for LFG-Based Pathways versus NA NG and Petroleum Gasoline and Diesel Pathways ......................................................................... 31

16 WTW GHG Emissions for LFG-Based Pathways Compared with NA NG and Petroleum Gasoline and Diesel Pathways ...................................................................... 33

17 Energy Use for CNG from LFG or Fossil NA NG, versus Petroleum Gasoline .............. 35

18 Fossil Fuel Use for CNG from LFG or Fossil NA NG, versus Petroleum Gasoline ........ 35

19 GHG Emissions for CNG from LFG or Fossil NA NG, versus Petroleum Gasoline ....... 36

20 Energy Use for LNG from LFG or Fossil NA NG, versus Petroleum Diesel................... 37

21 Fossil Fuel Use for LNG from LFG or Fossil NA NG, versus Petroleum Diesel............. 37

22 GHG Emissions for LNG from LFG or Fossil NA NG, versus Petroleum Diesel .......... 38

A-1 Schematics of NG Liquefaction Processes..................................................................... 49

B-1 CO Emissions for LFG-Based Pathways Compared with NA NG and Petroleum Gasoline and Diesel Pathways ........................................................................ 52

B-2 $\mathrm{NO}_{\mathbf{x}}$ Emissions for LFG-Based Pathways Compared with NA NG and Petroleum Gasoline and Diesel Pathways ..................................................................... 53

B-3 PM PM $_{10}$ Emissions for LFG-Based Pathways Compared with NA NG and Petroleum Gasoline and Diesel Pathways ...................................................................... 53 


\section{FIGURES (CONT.)}

B-4 PM 2.5 Emissions for LFG-Based Pathways Compared with NA NG and

Petroleum Gasoline and Diesel Pathways

B-5 $\mathrm{SO}_{\mathbf{x}}$ Emissions for LFG-Based Pathways Compared with NA NG and

Petroleum Gasoline and Diesel Pathways

\section{TABLES}

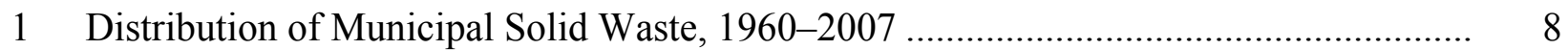

2 Composition and Characteristics of Biomethane and Fossil Natural Gas........................ 12

3 Assumptions for LFG-Based CNG/LNG, Fossil CNG/LNG, and

Petroleum Pathways …………………………………………………………….... 17

4 Emission Factors for LFG-Fueled IC Engines, LFG Flares, and

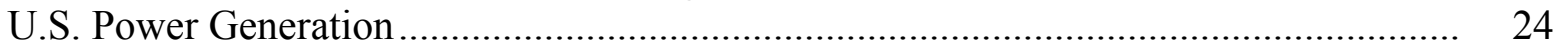

$5 \quad$ Plant Efficiencies of NG Liquefaction Technologies.................................................... 25

$6 \quad$ Emission Factors for Diesel- and LNG-Fueled Heavy-Duty Trucks ................................. 27

$7 \quad$ WTW Total Energy Use for LFG-to-CNG Pathways by Stage ....................................... 30

8 WTW Total Energy Use for LFG-to-LNG Pathways by Stage ...................................... 30

$9 \quad$ WTW Fossil Fuel Use for LFG-to-CNG Pathways by Stage .......................................... 31

10 WTW Fossil Fuel Use for LFG-to-LNG Pathways by Stage.......................................... 32

11 WTW GHG Emissions for LFG-to-CNG by Pathway Stage _.......................................... 33

12 WTW GHG Emissions for LFG-to-CNG by Pathway Stage.......................................... 33

13 WTW GHG Emissions for LFG-to-LNG by Pathway Stage ……………………........... 34

14 WTW GHG Emissions for LFG-to-LNG by Pathway Stage ............................................ 34

A-1 Process and Train Efficiencies of Major NG Liquefaction Processes ............................. $\quad 50$ 


\section{ACKNOWLEDGMENTS}

The authors gratefully acknowledge DOE's support and assistance in this effort. They also acknowledge the assistance of Jeffrey Hahn of Covanta-Haverhill, Inc., and Andrew Burnham, Amgad Elgowainy, and Thomas Wallner of Argonne's Center for Transportation Research, who provided their time and expertise to analyze and interpret data and advise us of its strengths and limitations; Stephanie Young (formerly of the California Integrated Waste Management Board), Scott Walker of the California Department of Resources and Recovery (CalRecycle), Chuck White of Waste Management, Inc., and John Barclay of Prometheus Energy, who provided access to documents and other resources; and Rachel Goldstein of USEPA, Jeffrey Clarke of NGVAmerica, and Sean Turner of Gladstein, Neandross \& Associates, who reviewed an earlier draft of this report. 


\section{WELL-TO-WHEELS ANALYSIS OF LANDFILL GAS-BASED PATHWAYS AND THEIR ADDITION TO THE GREET MODEL}

Marianne Mintz, Jeongwoo Han, Michael Wang, and Christopher Saricks

\section{EXECUTIVE SUMMARY}

Today, approximately 300 million standard cubic ft/day (mmscfd) of natural gas and $1600 \mathrm{MW}$ of electricity are produced from the decomposition of organic waste at 519 U.S. landfills (EPA 2010a). Since landfill gas (LFG) is a renewable resource, this energy is considered renewable. When used as a vehicle fuel, compressed natural gas (CNG) produced from LFG consumes up to $185,000 \mathrm{Btu}$ of fossil fuel and generates from 1.5 to $18.4 \mathrm{~kg}$ of carbon dioxide-equivalent $\left(\mathrm{CO}_{2} \mathrm{e}\right)$ emissions per million Btu of fuel on a "well-to-wheel" (WTW) basis. This compares with approximately 1.1 million Btu and $78.2 \mathrm{~kg}$ of $\mathrm{CO}_{2} \mathrm{e}$ per million Btu for CNG from fossil natural gas and 1.2 million Btu and $97.5 \mathrm{~kg}$ of $\mathrm{CO}_{2} \mathrm{e}$ per million Btu for petroleum gasoline. Because of the additional energy required for liquefaction, LFG-based liquefied natural gas (LNG) requires more fossil fuel (222,000-227,000 Btu/million Btu WTW) and generates more GHG emissions (approximately $22 \mathrm{~kg} \mathrm{CO}_{2} \mathrm{e} / \mathrm{MM}$ Btu WTW) if grid electricity is used for the liquefaction process. However, if some of the LFG is used to generate electricity for gas cleanup and liquefaction (or compression, in the case of CNG), vehicle fuel produced from LFG can have no fossil fuel input and only minimal GHG emissions (1.5-7.7 $\mathrm{kg} \mathrm{CO}_{2} \mathrm{e} / \mathrm{MM}$ Btu) on a WTW basis. Thus, LFG-based natural gas can be one of the lowest GHG-emitting fuels for lightor heavy-duty vehicles.

This report discusses the size and scope of biomethane resources from landfills and the pathways by which those resources can be turned into and utilized as vehicle fuel. It includes characterizations of the LFG stream and the processes used to convert low-Btu LFG into highBtu renewable natural gas $(\mathrm{RNG})$; documents the conversion efficiencies and losses of those processes, the choice of processes modeled in GREET, and other assumptions used to construct GREET pathways; and presents GREET results by pathway stage. GREET estimates of well-topump (WTP), pump-to-wheel (PTW), and WTW energy, fossil fuel, and GHG emissions for each LFG-based pathway are then summarized and compared with similar estimates for fossil natural gas and petroleum pathways. 


\section{INTRODUCTION}

Renewable energy is a growing part of the U.S. energy mix, rising from 4,076 trillion Btu (6.4\% of total energy production) in 1970 to approximately 6,800 trillion Btu $(9.5 \%$ of total energy production) in 2007 (EIA 2009a). To meet goals for reducing import dependence and greenhouse gas emissions, major efforts are under way to increase production of wind, solar, geothermal, and "next-generation" biofuels from energy crops, agricultural residues, wood waste, and other organic materials. Although the spotlight tends to focus on sophisticated new technologies, "low-tech" processes (like anaerobic digestion) have long produced renewable fuel. Biomethane from municipal solid waste (MSW) deposited in sanitary landfills is one such option. Comprising roughly one-half of the gaseous mixture known as landfill gas (LFG), this renewable energy source has only recently begun to be recovered in the United States. In the past, standard procedure was to either vent the gas or capture and flare it in a collection system (along with the other constituents in the mixture). While flaring reduces the global warming potential (GWP) of the LFG stream by a factor of eight, it fails to utilize the approximately $500 \mathrm{Btu} / \mathrm{standard}$ cubic $\mathrm{ft}$ (scf) in the stream. ${ }^{1}$

Today, 519 landfills recover energy from landfill gas (EPA 2010a). Projects range from small internal combustion engines or microturbines using LFG to generate power for site electrical needs to multiple generation units supporting site needs and exporting excess power to the grid. A few projects use power (generated on-site from the LFG or purchased from the electric grid) to purify the LFG stream, convert it into pipeline-quality natural gas (NG), and pressurize it either for injection into the NG pipeline system or use as a vehicle fuel. A handful of projects liquefy the natural gas to fuel buses or refuse trucks or to be sold into the bulk liquefied natural gas (LNG) market. These latter options - producing compressed natural gas $(\mathrm{CNG})$ or LNG and using it as a vehicle fuel or for injection into the pipeline system - are the focus of this report.

\subsection{BACKGROUND}

This project was undertaken in response to growing interest in applying well-to-wheels (WTW) analysis to renewable fuels. There are many motivations for this interest. Utilities are interested in identifying and pursuing options to meet renewable energy mandates. States considering low carbon fuel standards are interested in promoting lower carbon options, many of which are also renewable. The U.S. Environmental Protection Agency (EPA) is interested in reducing landfill emissions by assisting in LFG energy project development. The U.S. Department of Energy (DOE) is interested in providing information and guidance to support transparent, objective comparisons of alternative fuel production/delivery/utilization pathways.

There is also continued interest in reducing reliance on foreign energy sources. Natural gas is a clean-burning, domestic resource that produces fewer greenhouse gases (GHGs) per unit than petroleum gasoline or diesel. Supplies of this lower carbon fuel are plentiful now and likely

${ }^{1}$ See Section 3.1.1 for a discussion of net reductions in greenhouse gases (GHGs) and GWP achieved from flaring landfill gas. 
to remain so for the foreseeable future (see Section 1.2). Moreover, if sizable quantities of LFG-based NG were added to the NG fuel "pool," the carbon content of that pool could be reduced, rendering NG an even more attractive fuel choice.

This project applies WTW analysis to several LFG-based pathways. Energy consumption and GHG emissions for each of those pathways are quantified and compared with petroleum gasoline and North American natural gas (NA NG) pathways for producing, distributing, and utilizing the respective fuel in motor vehicles. This study is supported by DOE's Office of Vehicle Technologies (OVT). The OVT has long supported research on technologies to produce natural gas as a vehicle fuel, engine modifications to better utilize natural gas fuel, and analysis to determine the impacts of natural gas-based vehicle fuels. Some of that work, in support of pilot projects to demonstrate LFG-based vehicle fuel production, is included in the data base developed for this study.

\subsection{U.S. NATURAL GAS RESOURCES}

In the past decade, advanced "horizontal drilling" technology and historically high natural gas prices have spurred domestic drilling activity, in turn increasing natural gas reserves and motivating developers to seek new markets for natural gas. U.S. annual reserve additions have grown from a level where they barely kept up with NG production to one that is now more than double production (Figure 1). Most of these new reserves are from so-called unconventional sources, primarily coal-bed methane and shale gas, each of which now accounts for $9 \%$ of U.S. proved NG reserves (EIA 2008). By year-end 2007, the United States had 237.7 trillion cubic feet (tcf) of proved reserves of dry natural gas, the highest year-end volume in the 31 years that EIA (2008) has published such estimates.

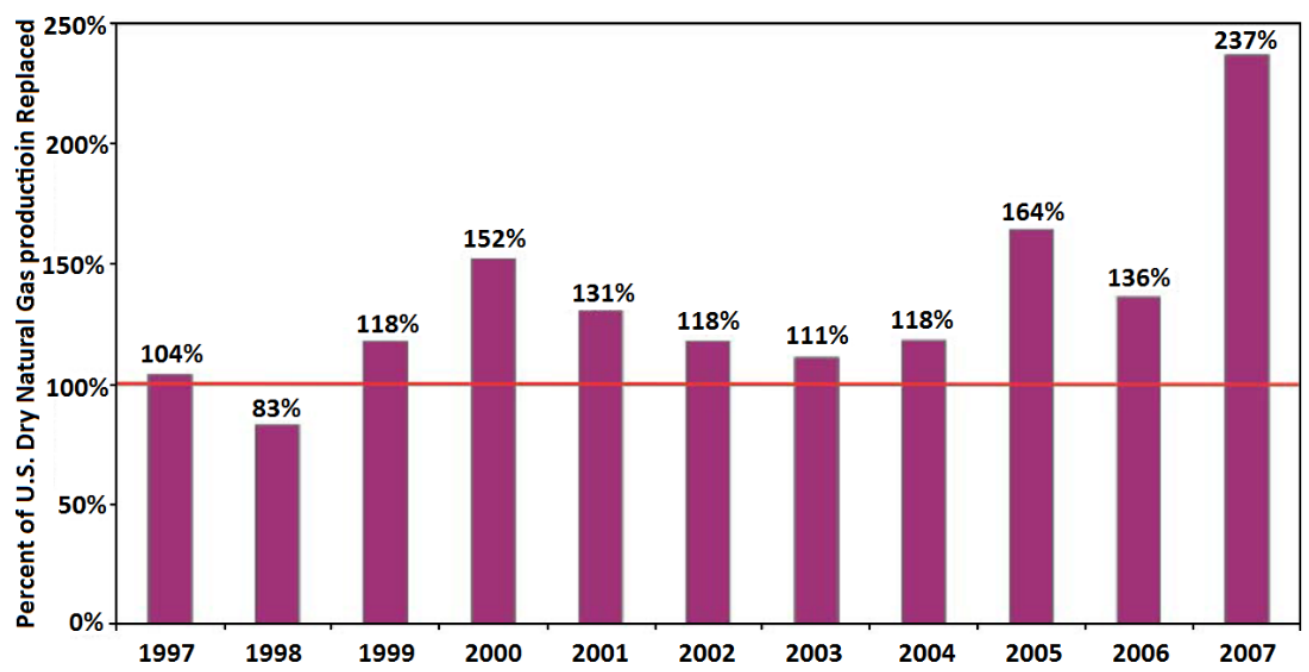

FIGURE 1 Natural Gas Reserve Additions as Percent of Annual Production, 1997-2007 (EIA 2008) 
In concert with vigorous exploration and production activity, NG pipeline construction has climbed to connect new supplies to the existing gas distribution infrastructure, as well as to expand distribution capacity system wide. In 2008, pipeline capacity increased by four times the average for the prior decade (Figure 2).

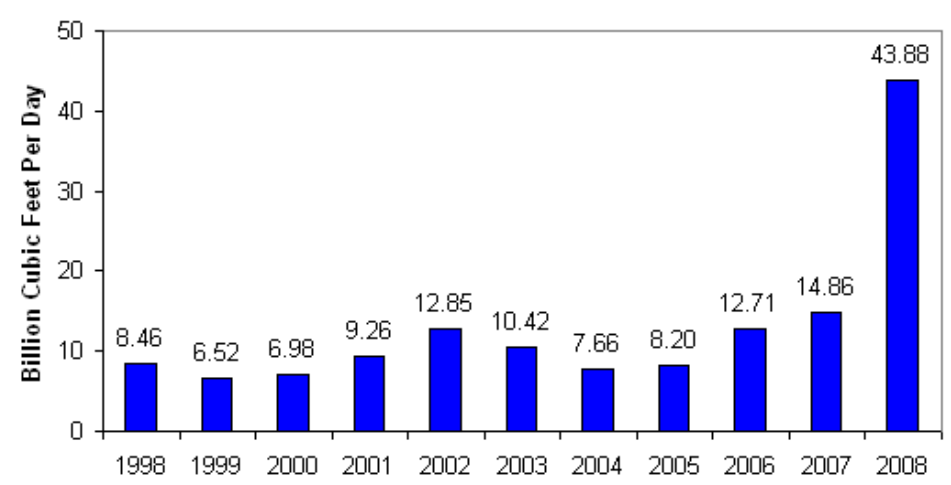

FIGURE 2 Pipeline Capacity Additions, 1998-2008 (EIA 2009b)

With increased reserves and distribution capacity, developers are looking for new natural gas markets. One possibility is to replace conventional coal-fired power plants with NG-fueled integrated-gasification-combined-cycle power plants. ${ }^{2}$ Another is to replace motor gasoline or diesel with lower-carbon natural gas. This latter option could be particularly attractive if the intent is to achieve deep $\mathrm{CO}_{2}$ cuts in sectors that currently have few economic, low-carbon alternatives. Transportation is one such sector. Resource developers like T.B. Pickens (2009) have targeted transportation vehicles as a potential new market for natural gas. Although compressed natural gas $(\mathrm{CNG})$-fueled vehicles have been available for many years, the lack of a widespread public fueling infrastructure has limited their appeal to all but centrally fueled fleets. Even then, many centrally fueled fleets have been reluctant to invest in additional fueling infrastructure and vehicles with uncertain resale values.

Uncertainty has been an especially strong barrier to the market acceptance of NG-fueled motor vehicles. Transit operators' need to meet ever-tougher exhaust emissions standards has spurred them to consider CNG or LNG-fueled buses. However, other technologies - like hybrids and a new generation of low-emission diesels - may also meet the standards. With no clear technology "winner," the looming prospect of a low-carbon fuel standard may be a persuasive argument for NG, particularly from low-carbon sources like landfill gas.

2 Note, however, that this option is most attractive when the difference between the cost of electricity and the cost of the fuel required to produce electricity is relatively small. Called the "spark spread," this difference narrowed over the past decade but has increased since 2007. 


\subsection{NATURAL GAS AS A VEHICLE FUEL}

Historically, natural gas has been used mostly for power production, space heating, industrial processes, and as a petrochemical feedstock. In the past decade, however, its relatively low emissions (as compared with diesel engines in internal combustion engines) have made it increasingly attractive as an urban bus fuel, especially in California where emission standards for nitrous oxides $\left(\mathrm{NO}_{\mathrm{x}}\right)$ and particulate matter $(\mathrm{PM})$ are particularly stringent. To use natural gas as a vehicle fuel, many transit operators have replaced diesel buses with CNG buses containing a new generation of spark-ignited engines. Fueling generally relies on existing local distribution pipelines to deliver the gas under relatively low pressure, compressors to increase the pressure to roughly $3600 \mathrm{psi}$ for on-site storage, and storage/dispensing systems to load the gas onto vehicles at 3000-3600 psi. Fleets that are not served by natural gas pipelines or that must travel a longer distance between fueling usually use liquefied natural gas (LNG), which is generally delivered in cryogenic tank trucks.

Spurred by California's Low Carbon Fuel Standard and the possibility of a similar national standard, there is increasing interest in vehicle fuels with lower carbon footprints. CNG and LNG derived from landfill gas are particularly promising. For each million Btu of energy, petroleum diesel contains 21,600 grams of carbon, while North American fossil-derived natural gas (NA NG) contains 16,200 grams. If only vehicle operation is taken into account, on a Btu-toBtu displacement basis, switching from petroleum diesel to NA fossil-based CNG can reduce carbon emissions by $25 \%$ (assuming comparable operating efficiencies). As shown in Section 3.1, switching from NA fossil-based CNG to LFG-based CNG can reduce carbon emissions much more.

\subsection{RENEWABLE NATURAL GAS AND GHG EMISSIONS}

Natural gas derived from LFG is considered a renewable fuel since the original source of the carbon, in the decomposed waste, can be traced back to organic sources that naturally replenish it. It is also a low-carbon fuel. Whether in the form of CNG or LNG, LFG-based NG has negative GHG emissions since its conversion to vehicle fuel displaces GHG emissions that would have occurred if the LFG had been oxidized into $\mathrm{CO}_{2}$ in the landfill flare.

Renewable natural gas is particularly attractive to utilities subject to renewable fuel mandates. LFG-based CNG or LNG is attractive to fleet operators in states with low-carbon fuel standards. Since natural gas is fungible, the entity purchasing the rights to a supply of LFG-based NG need not take physical possession of it to gain renewable fuel credits.

\subsection{FUEL CYCLE ANALYSIS}

To understand a fuel's impact, the entire fuel cycle - from production of raw materials to delivery and end use - must be considered. This requires a systematic accounting of the energy and emissions of each stage in the cycle, from "well" to "wheel" (WTW). This study was undertaken to characterize pathways for producing vehicle fuel from landfill gas, estimate WTW 
energy and GHG emissions at each stage in these pathways, and compare results with petroleumand fossil NG-based alternatives. In this context, the "well" is the landfill gas resource and the "wheel" is the vehicle consuming the fuel.

The analysis was conducted by using the GREET (Greenhouse gases, Regulated Emissions, and Energy use in Transportation) model created by Argonne National Laboratory. Developed in Microsoft ${ }^{\circledR}$ Excel with a graphical user interface, GREET is structured to systematically account for a range of potential feedstocks, fuels, and conversion processes for any defined WTW pathway. Downloadable at http://www.transportation.anl.gov/ modeling_simulation/GREET/, GREET calculates emissions of three greenhouse gases $\left(\mathrm{CO}_{2}\right.$, $\mathrm{CH}_{4}$, and $\mathrm{N}_{2} \mathrm{O}$ ) and six criteria pollutants (VOC, $\mathrm{CO}, \mathrm{NO}_{\mathrm{x}}, \mathrm{SO}_{\mathrm{x}}, \mathrm{PM}_{10}$, and $\mathrm{PM}_{2.5}$ ) and consumption of each of the following: total energy, fossil fuel, petroleum, natural gas, and coal.

In the years since its development, GREET has become a familiar and respected tool for evaluating vehicle technologies and fuels on a consistent, systematic basis. Working with industry and government experts, Argonne continues to upgrade and update the GREET model. With support from the U.S. Department of Energy (DOE), Argonne has added a number of hydrogen production pathways for stationary and mobile internal combustion engine and fuel cell applications and extensive simulations of biofuel production pathways. Most recently, Argonne has upgraded simulations of plug-in hybrid electric vehicles (PHEVs) in GREET. The most recent GREET fuel-cycle model (GREET1.8d.0) was released in June 2010. Currently, there are more than 10,000 registered GREET users.

\subsection{SCOPE}

As stated above, this report documents the conceptual approach, data, and initial results for a set of LFG-to-vehicle fuel pathways. These landfill gas-based pathways have been added to GREET 1.8d.0.

The report itself is organized into five sections, supplemented by two appendices. Following this brief Introduction, Section 2 describes the size and characteristics of the LFG resource base, while Section 3 discusses WTW pathways, their key stages, and important features of the fuel cycle analysis. In Sections 4 and 5, estimates of well-to-wheel (WTW) fossil fuel use and GHG emissions are presented and conclusions are discussed. Appendix A provides additional detail on liquefaction assumptions and Appendix B presents estimates of WTW emissions of criteria pollutants. 


\section{LANDFILL GAS}

At present, most of the biomethane generated at U.S. landfills is flared in conjunction with emissions-abatement practices. (For further discussions of flaring and "reference case" assumptions, see Sections 2.1 and 3.1.) Relative to venting, flaring reduces criteria pollutant and GHG emissions, but it captures none of the energy (approximately $500 \mathrm{Btu} / \mathrm{scf}$ ) in the gas that is burned. ${ }^{3}$ Moreover, by destroying a valuable energy resource, it precludes the generation of additional revenue by the landfill owner - either as energy sales or in various forms of carbon and renewable energy credits. For these reasons, there is increasing interest in converting methane in the collected LFG into usable energy like natural gas, hydrogen, methanol, ethanol, or electricity. This study investigates the potential for WTW energy and GHG emission benefits as the result of producing LFG-based natural gas for vehicle use.

\subsection{RESOURCE BASE}

Since the mid-1960s, sanitary landfills have been the main disposal method for municipal solid waste (MSW) in the United States. In 2007, there were an estimated 1,754 "active" landfills, accepting 137 million tons of waste annually, or approximately 54\% of the total MSW generated in the United States (EPA 2008). ${ }^{4}$ As shown in Table 1 and Figure 3, this share has been dropping steadily since 1960 .

An additional 6,000 landfills are inactive (i.e., no longer receiving waste). ${ }^{5}$ Over their lifetime, landfills produce significant quantities of landfill gas (LFG), primarily methane $\left(\mathrm{CH}_{4}\right)$ and carbon dioxide $\left(\mathrm{CO}_{2}\right)$, from the anaerobic decomposition of organic materials, which typically comprise some $60 \%$ of the waste-to-landfill stream. The EPA actively monitors emission compliance and energy recovery at active landfills, the latter through its Landfill Methane Outreach Program (LMOP). Figure 4, produced from a model developed by EPA's LMOP, illustrates a typical LFG generation and recovery profile for a site opened in 1980, at which peak recovery occurs in 2014 (EPA 2008). In conventional landfills, gas recovery typically begins a decade or more after the waste is deposited and continues for several decades. In newer designs (e.g., conventional cells with leachate circulation, bioreactors, or anaerobic

3 In 1994, EPA created the Landfill Methane Outreach Program (LMOP) to help reduce methane emissions from landfills by encouraging the recovery and use of landfill gas (LFG) as an energy resource. LMOP is a voluntary program to promote alliances among states, energy users and providers, landfill owners and operators, and communities by providing information, analysis, and support for LFG-to-energy projects.

4 The other $46 \%$ consists of construction waste from new construction or remodeling activities, debris from the demolition of buildings and roads, industrial waste from manufacturing processes, and wastes banned from the MSW waste stream (including MSW ash and medical waste).

5 Inactive landfills must comply with EPA post-closure requirements, which include monitoring and maintaining waste containment systems and monitoring groundwater to ensure that waste is not escaping and polluting the surrounding environment. These activities are generally required for 30 years from site closure. During this time, inactive landfills continue to emit methane and other gases. At larger landfills equipped with gas collection systems, LFG is usually captured and flared in a thermal oxidizer. At smaller landfills, LFG is usually uncontrolled. 
TABLE 1 Distribution of Municipal Solid Waste, 1960-2007 (EPA 2008)

\begin{tabular}{|c|c|c|c|c|c|c|c|c|c|}
\hline \multirow[b]{2}{*}{ Activity } & \multicolumn{9}{|c|}{ Percent of Total Generation } \\
\hline & 1960 & 1970 & 1980 & 1990 & 2000 & 2004 & 2005 & 2006 & 2007 \\
\hline Generation & 100 & 100 & 100 & 100 & 100 & 100 & 100 & 100 & 100 \\
\hline Recovery for recycling & 6.4 & 6.6 & 9.6 & 14.2 & 22.1 & 23.0 & 23.5 & 24.1 & 24.9 \\
\hline Recovery for composting ${ }^{a}$ & Neg. & Neg. & Neg. & 2.0 & 6.9 & 8.2 & 8.2 & 8.2 & 8.5 \\
\hline Total materials recovery & 6.4 & 6.6 & 9.6 & 16.2 & 29.0 & 31.2 & 31.7 & 32.3 & 33.4 \\
\hline Combustion with energy recovery ${ }^{\mathrm{b}}$ & 0.0 & 0.3 & 1.8 & 14.5 & 14.1 & 12.6 & 12.6 & 12.6 & 12.6 \\
\hline Discards to landfill, other disposal $^{\mathrm{c}}$ & 93.6 & 93.1 & 88.6 & 69.3 & 56.9 & 56.2 & 55.7 & 55.1 & 54.0 \\
\hline
\end{tabular}

Pounds per Person per Day

\begin{tabular}{lccccccccc}
\multicolumn{1}{c}{ Activity } & 1960 & 1970 & 1980 & 1990 & 2000 & 2004 & 2005 & 2006 & 2007 \\
\hline & & & & & & & & & \\
Generation & 2.68 & 3.25 & 3.66 & 4.50 & 4.65 & 4.66 & 4.63 & 4.65 & 4.62 \\
Recovery for recycling $_{\text {Recovery for composting }}{ }^{\mathrm{a}}$ & 0.17 & 0.22 & 0.35 & 0.64 & 1.03 & 1.07 & 1.09 & 1.12 & 1.15 \\
Total materials recovery $_{\text {Combustion with energy recovery }^{\mathrm{b}}}^{\mathrm{c}}$ & $\mathrm{Neg}$. & $\mathrm{Neg}$. & $\mathrm{Neg}$. & 0.09 & 0.32 & 0.38 & 0.38 & 0.38 & 0.39 \\
Discards to landfill, other disposal $^{\mathrm{c}}$ & 0.00 & 0.22 & 0.35 & 0.73 & 1.35 & 1.45 & 1.47 & 1.50 & 1.54 \\
\hline
\end{tabular}

${ }^{a}$ Includes composting of yard trimmings, food scraps, and other MSW organic material; excludes backyard composting.

${ }^{\mathrm{b}}$ Includes combustion of MSW in mass burn or refuse-derived fuel form and combustion with energy recovery of source-separated materials in MSW (e.g., wood pallets and tire-derived fuel).

${ }^{c}$ Discards after recovery minus combustion with energy recovery. Discards include combustion without energy recovery. Details may not add to totals due to rounding.

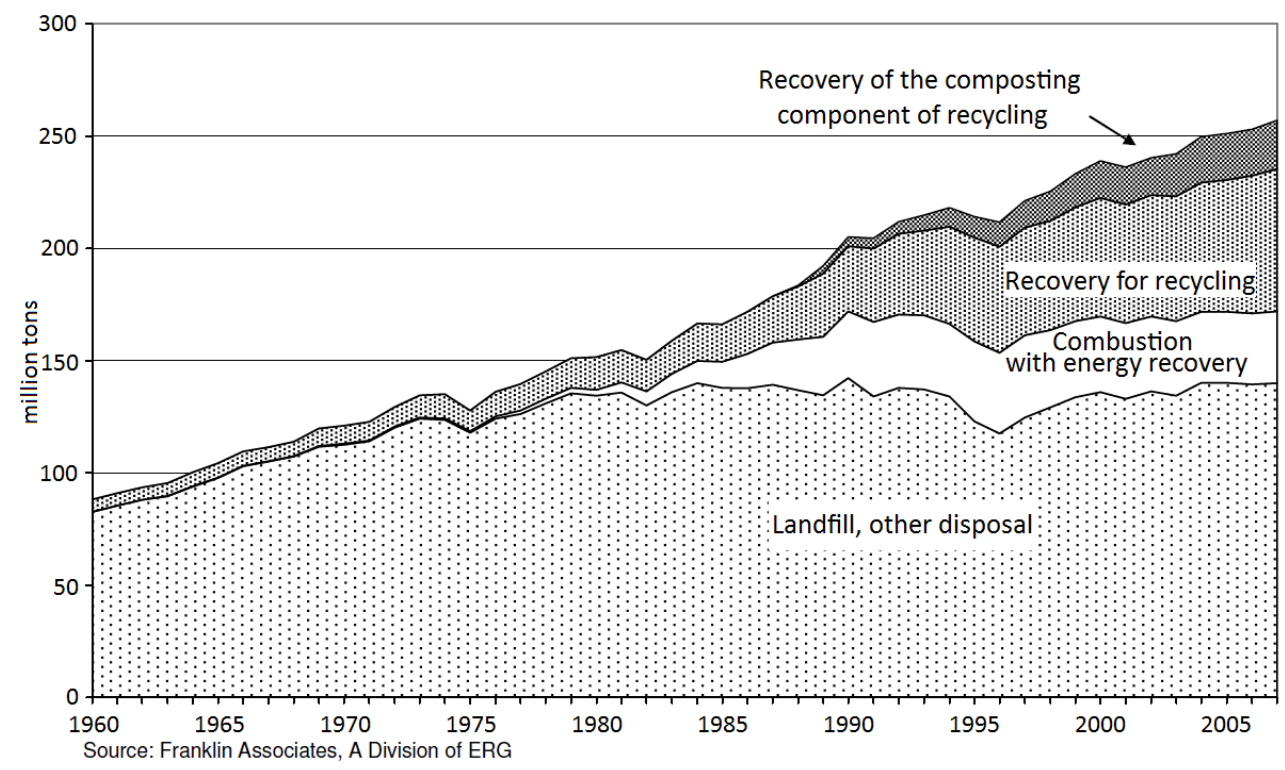

FIGURE 3 Disposition of Municipal Solid Waste, 1960-2007 (EPA 2008) 


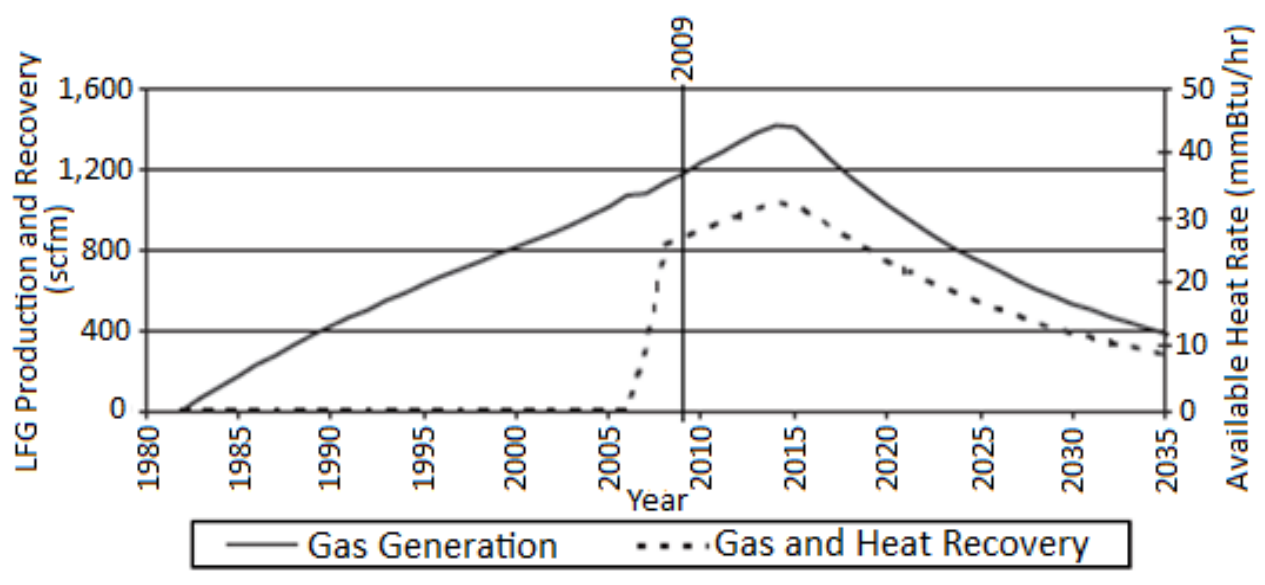

FIGURE 4 Typical Landfill Gas Production and Recovery Profile

digestion of organics), accelerated waste stabilization permits economic recovery to begin much earlier, typically within 5-10 years of waste deposition (University of Florida and University of Central Florida 2008).

Because of its high methane content, LFG can be explosive, as well as a potent source of greenhouse gases. It is also a major source of non-methane organic compounds (NMOCs), a precursor of ground-level ozone formation. Historically, a system of vertical wells drilled into landfills was used to dilute the concentration of $\mathrm{CH}_{4}$ in the landfill to a level below methane's explosive limit (5-15 percent), thereby controlling the explosion hazard. Most NMOC emissions have been controlled since 1996, when landfills with a permitted capacity greater than 2.5 million cubic meters of waste were brought under the Landfill Rule of the Clean Air Act, which requires them to have collection systems consisting of low-pressure wells, horizontal pipes, and blowers to capture the LFG and a flare or thermal oxidizer to destroy it. ${ }^{6}$ (Thus, some $98 \%$ of NMOCs are converted to less toxic compounds and $99.9 \%$ of the methane is oxidized to $\left.\mathrm{CO}_{2}\right) .^{7}$ Although collection efficiencies reportedly range from 50 to $90 \%$, EPA estimates an average value of $75 \%$ for inventory purposes (EPA 1995). Methane in the remaining $25 \%$ of LFG that is uncontrolled (i.e., the area between the two curves in Figure 4) is typically oxidized to $\mathrm{CO}_{2}$ or converted to other compounds by microbes in the landfill cover soil. Some of these compounds eventually are emitted to the atmosphere; some remain in the soil.

${ }^{6}$ Of California's 367 municipal solid waste landfills, $218(59 \%)$ have a permitted capacity of less than 2.5 million $\mathrm{m}^{3}$ (CARB 2009). Nationally, approximately $46 \%$ of the waste in the ground is not covered by the landfill gas rule. Presumably, much of the excluded waste is at small landfills.

7 On June 25, 2009, the California Air Resources Board (CARB) ruled that all previously uncontrolled MSW landfills in that state (i.e., those with permitted capacities below 2.5 million $\mathrm{m}^{3}$ ) must design and install gas collection systems by 2012 and that currently controlled landfills must improve gas collection efficiency (CARB 2009). 


\subsection{RESOURCE DEVELOPMENT}

As of April 2010, EPA reports that 519 projects are recovering energy from landfills (EPA 2010a). More than $70 \%$ of these projects generate power; most of the others minimally process the LFG and use it in boilers or various manufacturing applications (Godlove 2010). Approximately 13 billion kWh of electricity and 102 billion cubic feet (bcf) of natural gas are generated each year from recovered LFG (Godlove 2010), representing about $0.3 \%$ of U.S. electricity and $0.3 \%$ of U.S. natural gas consumption (EIA 2009a).

Some 32 projects currently convert LFG into high-Btu NG or "renewable natural gas" (RNG), mostly for injection into the pipeline system (Godlove 2010). A handful of these projects include vehicle fueling, either as CNG or LNG (Ludwig 2009). In the past, these latter projects have tended to be pre-commercial or pilot scale. Now, however, several are coming on line at commercial scale or growing to commercial scale as second phases become operational. These latter projects include:

- Altamont Landfill LFG-to-LNG in Livermore, CA

- Frank R. Bowerman Landfill LFG-to-LNG in Orange County, CA

- Franklin County Landfill LFG-to-CNG in Columbus, $\mathrm{OH}$

- McCommas Bluff Landfill LFG-to-CNG and pipeline gas in Dallas, TX

- Rumpke Landfill LFG-to-CNG and pipeline gas in Cincinnati, OH

To the extent possible, these projects are included in the database developed for this analysis. Data on the following North American pilot-scale projects are also included in the database:

- Central Landfill LFG-to-CNG in Sonoma County, CA

- Burlington County Landfill LFG-to-LNG in NJ

- Puente Hills Landfill LFG-to-CNG in Los Angeles, CA

- Les Entreprises Berthier Inc. (EBI) Landfill LFG-to-pipeline gas in Quebec

- Highland Valley Copper Landfill LFG-to-pipeline gas in Vancouver

Figure 5 shows operational LFG-to-energy projects as of April 2010, as well as landfills identified by the EPA's LMOP as candidates for future projects.

\subsection{ADDITIONS TO THE RESOURCE BASE}

In addition to the "in place" LFG resource, LFG continues to be generated by MSW decomposition. Lear and Burdelski (2009) estimate that the current U.S. population generates some 27 billion cubic $\mathrm{ft}$ (bcf) of "new" LFG each year, equivalent to approximately 121 million gal of gasoline. 

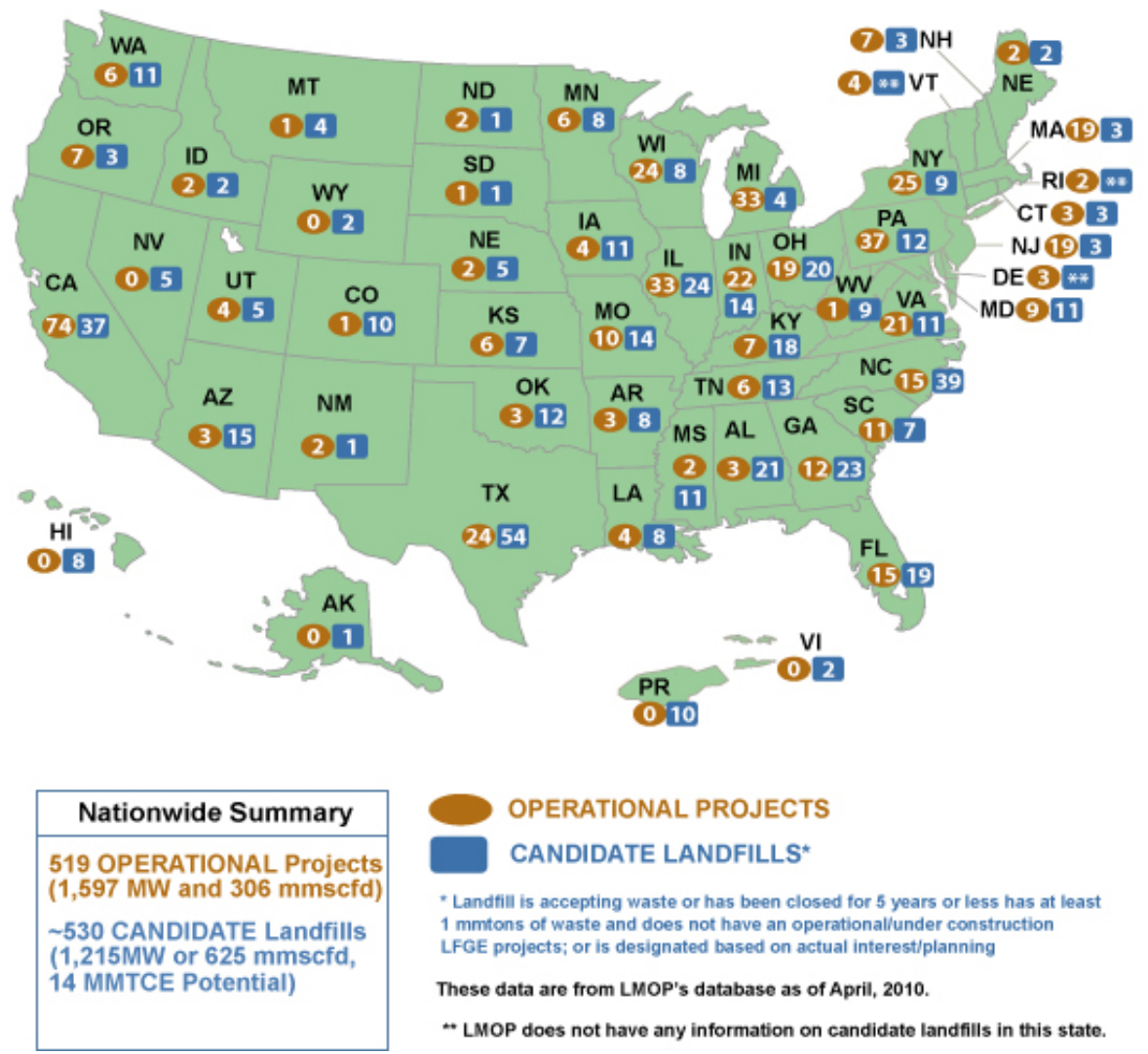

FIGURE 5 Operational LFG-to-Energy Projects and Candidate Landfills by State (EPA 2010a)

\subsection{LANDFILL GAS COMPOSITION}

As shown in Table 2, methane $\left(\mathrm{CH}_{4}\right)$ is the predominant constituent in both fossil natural gas and LFG. Although gas composition varies from one site to another, LFG typically contains around $45-50 \%$ methane $\left(\mathrm{CH}_{4}\right), 35-40 \%$ carbon dioxide $\left(\mathrm{CO}_{2}\right)$, and $10-15 \%$ nitrogen $\left(\mathrm{N}_{2}\right)$, with smaller amounts of hydrogen $\left(\mathrm{H}_{2}\right)$, oxygen $\left(\mathrm{O}_{2}\right)$, hydrogen sulfide $\left(\mathrm{H}_{2} \mathrm{~S}\right)$, and ammonia $\left(\mathrm{NH}_{3}\right)$. The gas is usually saturated with water vapor.

LFG may contain more than 500 different contaminants, including a variety of sulfur compounds that are corrosive in the presence of water, halogenated compounds (e.g., carbon tetrachloride, chlorobenzene, chloroform) that produce corrosive combustion products, and organic silicon compounds (e.g., siloxanes) that form siliceous deposits in downstream applications - like internal combustion engines (Persson et al. 2006). Thus, an initial cleanup or pre-purification step is needed before LFG can be used in any application involving combustion. 
TABLE 2 Composition and Characteristics of Biomethane and Fossil Natural Gas

\begin{tabular}{|c|c|c|c|c|c|c|c|}
\hline \multicolumn{2}{|c|}{ Parameter } & \multirow[t]{2}{*}{ Unit } & EU LFG & $\begin{array}{c}\text { EU AD-Based } \\
\text { Biogas }\end{array}$ & \multirow[t]{2}{*}{$\begin{array}{c}\text { NG from NA } \\
\text { Gas Field }\end{array}$} & \multirow{2}{*}{$\begin{array}{c}\text { NG from NNA } \\
\text { Gas Field } \\
\\
\text { (Segeler 1965) }\end{array}$} & \multirow[t]{2}{*}{$\begin{array}{c}\text { NG distributed in } \\
\text { US }\end{array}$} \\
\hline Source & & & \multicolumn{2}{|c|}{ (Persson et al. 2006) } & & & \\
\hline LHV: & $\begin{array}{r}\text { average } \\
\text { range }\end{array}$ & $\mathrm{Btu} / \mathrm{ft}^{3}$ & 406 & 584 & $\begin{array}{c}1081 \\
835-1336\end{array}$ & $\begin{array}{c}1145 \\
627-1717\end{array}$ & $\begin{array}{c}1049 \\
945-1121\end{array}$ \\
\hline Density & $\begin{array}{c}\text { average } \\
\text { range }\end{array}$ & $\mathrm{g} / \mathrm{ft}^{3}$ & 34.8 & 32.1 & $\begin{array}{c}22.4 \\
19.5-27.9\end{array}$ & $\begin{array}{c}23.9 \\
19.5-36.9\end{array}$ & $\begin{array}{c}21.5 \\
20.3-24.6\end{array}$ \\
\hline $\mathrm{CH}_{4}:$ & $\begin{array}{r}\text { average } \\
\text { range }\end{array}$ & vol \% & $\begin{array}{c}45 \\
36-65\end{array}$ & $\begin{array}{c}63 \\
53-70\end{array}$ & $\begin{array}{c}51.5 \\
84.7-98.8\end{array}$ & $\begin{array}{c}77.0 \\
22.8-98.0\end{array}$ & $\begin{array}{c}89.4 \\
72.8-95.2\end{array}$ \\
\hline $\mathrm{H} 2:$ & average & vol \% & $0-3$ & 0 & - & - & - \\
\hline $\mathrm{CO}_{2}:$ & $\begin{array}{r}\text { average } \\
\text { range }\end{array}$ & vol \% & $\begin{array}{c}40 \\
15-50\end{array}$ & $\begin{array}{c}47 \\
30-47\end{array}$ & $\begin{array}{c}0.55 \\
0-6.0\end{array}$ & $\begin{array}{c}4.1 \\
0-29.0\end{array}$ & $\begin{array}{c}0.7 \\
0-2.0\end{array}$ \\
\hline $\mathrm{N}_{2}$ & $\begin{array}{r}\text { average } \\
\text { range }\end{array}$ & vol \% & $\begin{array}{c}15 \\
5-40\end{array}$ & $\begin{array}{c}0.2 \\
-\end{array}$ & $\begin{array}{c}4.03 \\
0-29.4\end{array}$ & $\begin{array}{c}1.7 \\
0-12.1\end{array}$ & $\begin{array}{c}2.9 \\
0-17.1\end{array}$ \\
\hline $\mathrm{O}_{2}$ : & $\begin{array}{r}\text { average } \\
\text { range }\end{array}$ & vol \% & $\begin{array}{c}1 \\
0-5\end{array}$ & $\begin{array}{l}0 \\
-\end{array}$ & $\begin{array}{c}0.06 \\
0-0.4\end{array}$ & $\begin{array}{c}0.1 \\
0-1.4\end{array}$ & $\begin{array}{c}0.0 \\
0-0.4\end{array}$ \\
\hline $\mathrm{H}_{2} \mathrm{~S}:$ & $\begin{array}{r}\text { average } \\
\text { range }\end{array}$ & ppmv & $\begin{array}{l}<100 \\
0-100\end{array}$ & $\begin{array}{c}<1000 \\
0-10000\end{array}$ & $\begin{array}{c}100 \\
0-3100\end{array}$ & $\begin{array}{c}400 \\
0-5200\end{array}$ & \\
\hline $\begin{array}{l}\text { NMOC: } \\
\text { (as Hex }\end{array}$ & $\begin{array}{l}\text { average } \\
\text { ne) range }\end{array}$ & ppmv & & & $\begin{array}{c}1100 \\
0-6600\end{array}$ & $\begin{array}{c}2000 \\
0-17000\end{array}$ & $\begin{array}{c}400 \\
0-1400\end{array}$ \\
\hline $\mathrm{NH}_{3}$ & & ppm & 5 & $<100$ & - & - & - \\
\hline
\end{tabular}




\section{FUEL CYCLE ANALYSIS OF LANDFILL-GAS-BASED PATHWAYS}

\subsection{LFG REFERENCE CASE}

The benchmark or reference case is critical to estimating the change in energy and emissions associated with introducing any new fuel or vehicle technology. For fossil fuels, the question is usually trivial - were it not for development of the resource to produce the new fuel, energy and emissions would not occur. Although process energy use and vehicle emissions may change in response to mandates requiring different fuel properties (e.g., low-sulfur diesel in place of conventional diesel, or reformulated gasoline in place of unleaded gasoline), the resulting "new" fuel comes from the same feedstock as before, and the benchmark or reference is the "old" fuel. Thus, the energy and GHG impact of the "new" fuel is simply the difference between the values associated with the "new" and "old" fossil fuels.

This is not usually the case with renewable fuels. If the feedstock historically has not been used to produce fuel, the energy and GHG impact of the new fuel is the difference between energy and GHG emissions associated with the resource's typical prior use (i.e., the pathway or reference case) and its new one. With respect to landfill gas, the key questions are:

- What is the typical prior use for LFG?

- Would the LFG have been produced in a conventional landfill, gathered in a standard gas collection system, and flared? Or, would it have been produced some other way? With different constituents? With more methane emitted to the atmosphere?

- At what point does the new LFG pathway diverge from the old?

Since we are concerned with the difference in energy and GHG emissions between the two pathways, the answer to the last of the above questions helps bound our system. Shared stages can be ignored since they are in both "old" and "new" pathways. Thus, for example, gas that continues to be flared ("Flared LFG" in Figure 6) is excluded from LFG-based pathways, which are labeled as cases within the dashed system boundary shown in Figure 6.

\subsubsection{Flaring versus Venting Landfill Gas}

Since the mid-1990s MSW landfills with a design capacity of 2.5 million $\mathrm{m}^{3}$ or more have been regulated under the Landfill Rule of the Clean Air Act (EPA 2000). To reduce emissions of volatile organic compounds, air toxics, and methane, these large landfills are required to install collection wells into the landfill and route the gas to a suitable energy recovery or combustion device (flare), to monitor surface methane on a quarterly basis, and to expand their collection systems if the methane concentration exceeds 500 parts per million.

As shown in Figure 7, flaring dramatically reduces the impact of carbon contained in organic waste. Emitted to the atmosphere as $\mathrm{CH}_{4}$, the carbon in the waste has a $\mathrm{CO}_{2}$ equivalence 
of 368 ; emitted as $\mathrm{CO}_{2}$, the equivalence is reduced to 44 . The resulting ratio $(368 / 44=8.36)$ is the relative benefit of flaring over venting the landfill gas.

The Landfill Rule succeeded in reducing VOCs and air toxics and in cutting methane emissions by over 37 million metric tons (EPA 1996). Few would argue that the approximately $\$ 2.2$ million in capital and $\$ 190,000$ in annual operating cost required to retrofit each covered landfill was not money well spent (EPA 1996). However, it was soon recognized that the energy in the flared gas, roughly $500 \mathrm{Btu} / \mathrm{ft}^{3}$, could be more productively utilized. Thus, EPA's Landfill Methane Outreach Program (LMOP) was created to encourage the recovery and use of LFG as an energy resource. LMOP currently has over 800 partners - including energy providers, landfill owners and operators, and host communities - involved in LFG-to-energy projects.

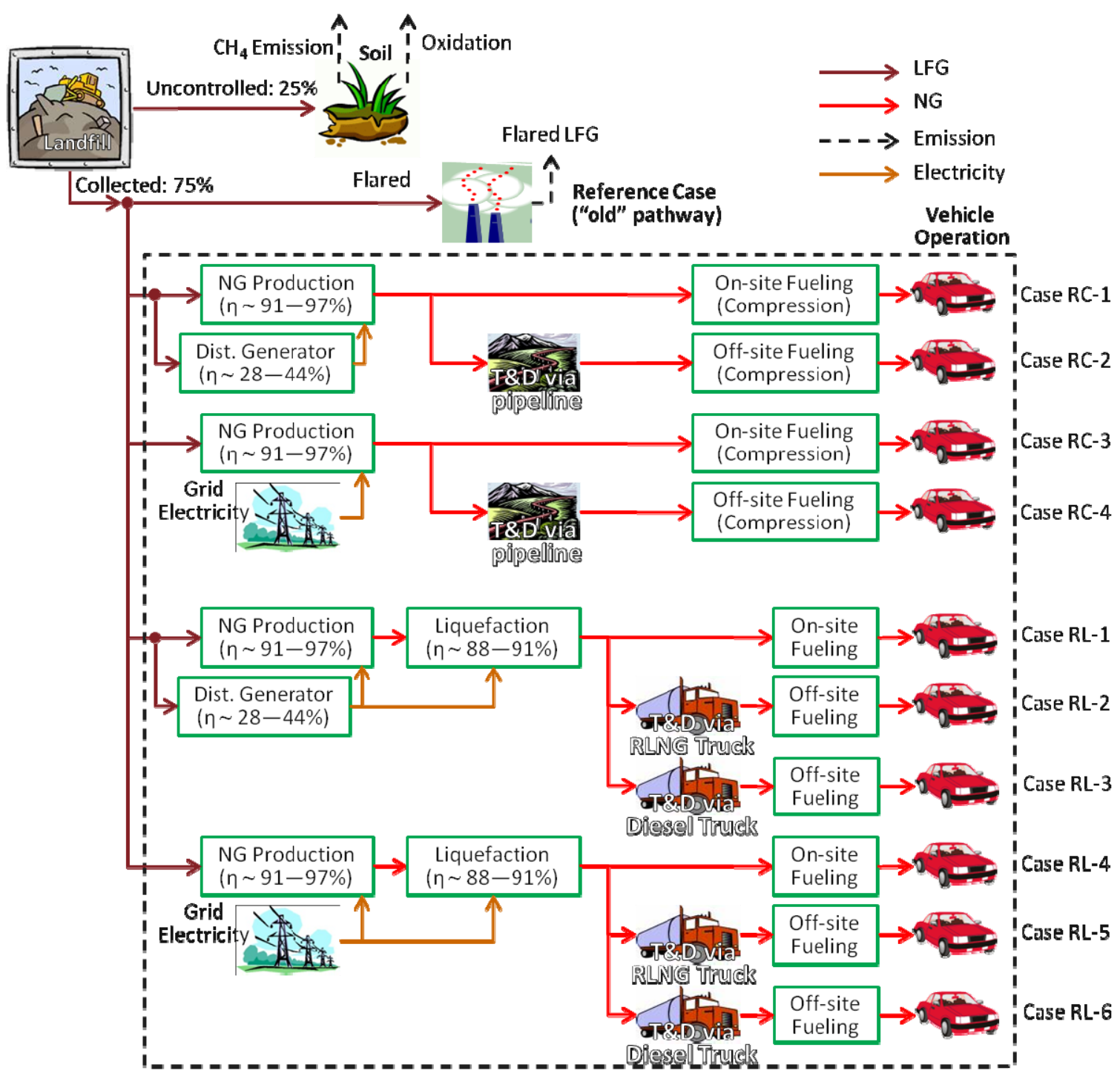

FIGURE 6 Fuel Cycle for Landfill-Gas-Based CNG and LNG, as Used in GREET Modeling 


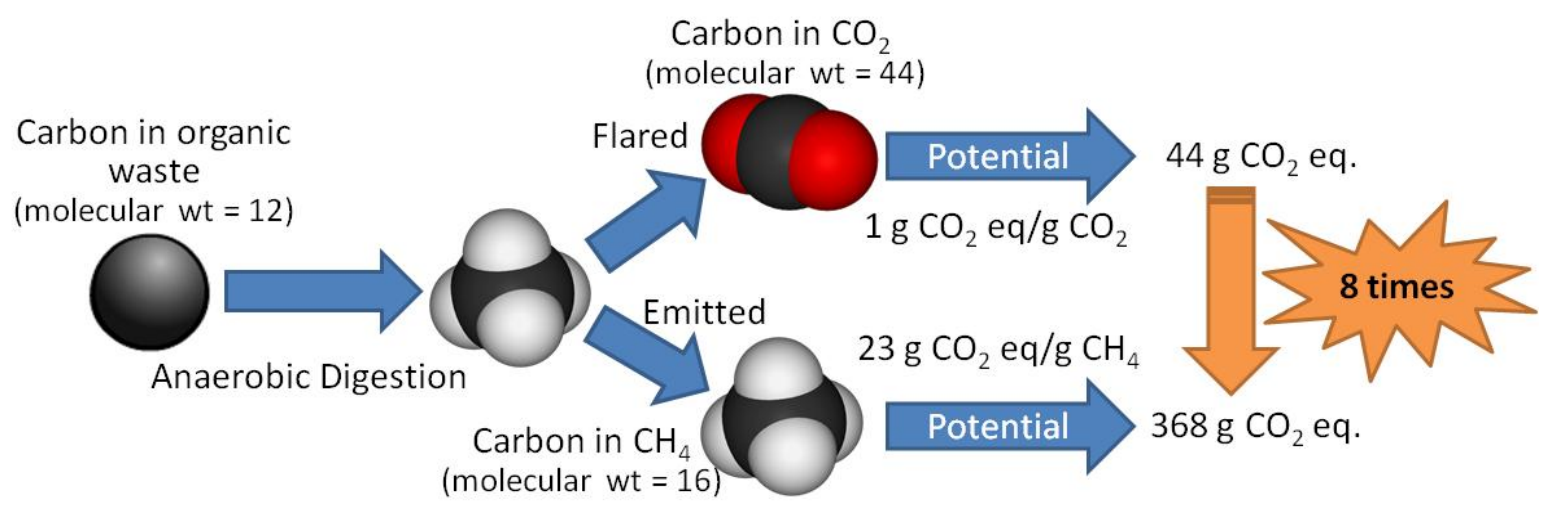

FIGURE $7 \mathrm{CO}_{2}$ Equivalent Emissions of Flaring versus Venting Landfill Gas

\subsubsection{Carbon Fate in LFG, Fossil NG and Petroleum Fuel Cycles}

As discussed above, flaring emits $\mathrm{CO}_{2}$. Purifying the LFG and converting it into CNG or LNG for vehicle fuel still emits $\mathrm{CO}_{2}$. However, the $\mathrm{CO}_{2}$ would have been emitted anyway (hence, there is no net addition). Moreover, the $\mathrm{CO}_{2}$ from LFG displaces a near equivalent amount of $\mathrm{CO}_{2}$ from fossil fuels (natural gas or petroleum) that would have been emitted if the vehicles operating on LFG-derived CNG/LNG had not been converted from their original fossil fuel.

Figures 8-10 depict the various stages of the LFG, fossil NG, and petroleum fuel cycles, showing where carbon is emitted to the atmosphere. As discussed earlier, the LFG fuel cycle (Figure 8) begins with gas collection, which is assumed to capture $75 \%$ of the total LFG produced. A portion of the collected carbon is assumed to be flared, either in waste gas from the purification process or as excess LFG that cannot be processed. Carbon is also emitted in transportation and distribution (T\&D) and vehicle operation.

For comparison purposes, Figures 9 and 10 show fossil NG and petroleum fuel cycles. As in the LFG fuel cycle, carbon is emitted in feedstock production, processing/refining, T\&D, and vehicle operation. 


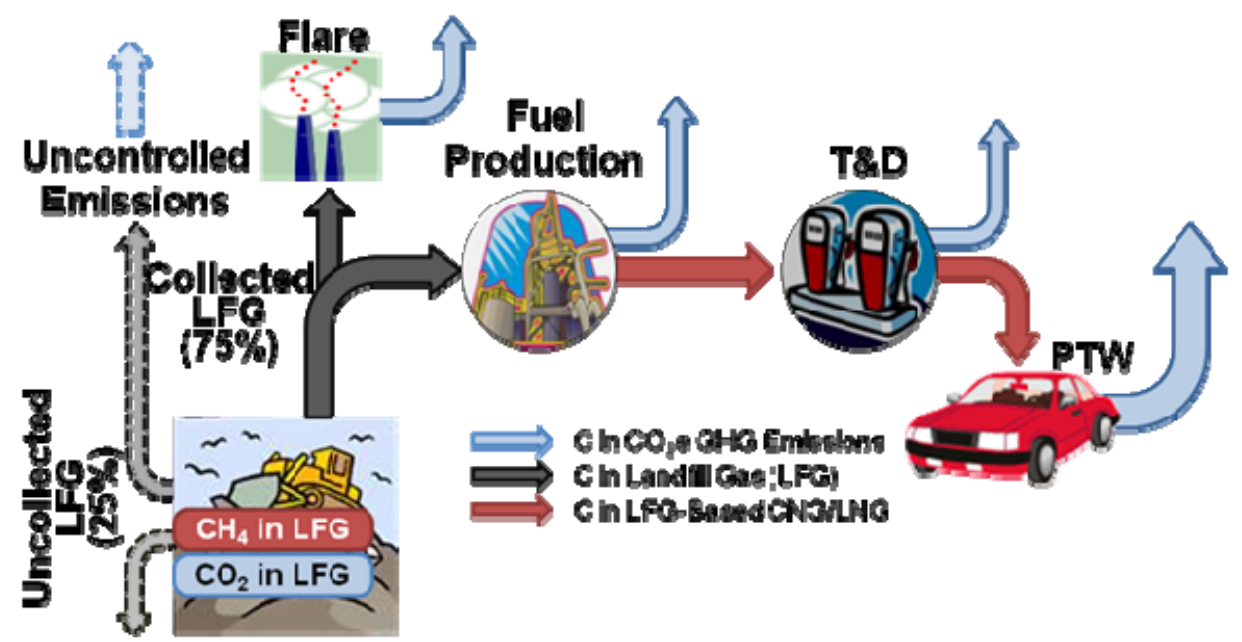

FIGURE $8 \mathrm{CO}_{2}$ Emissions in LFG-to-CNG/LNG Fuel Cycle

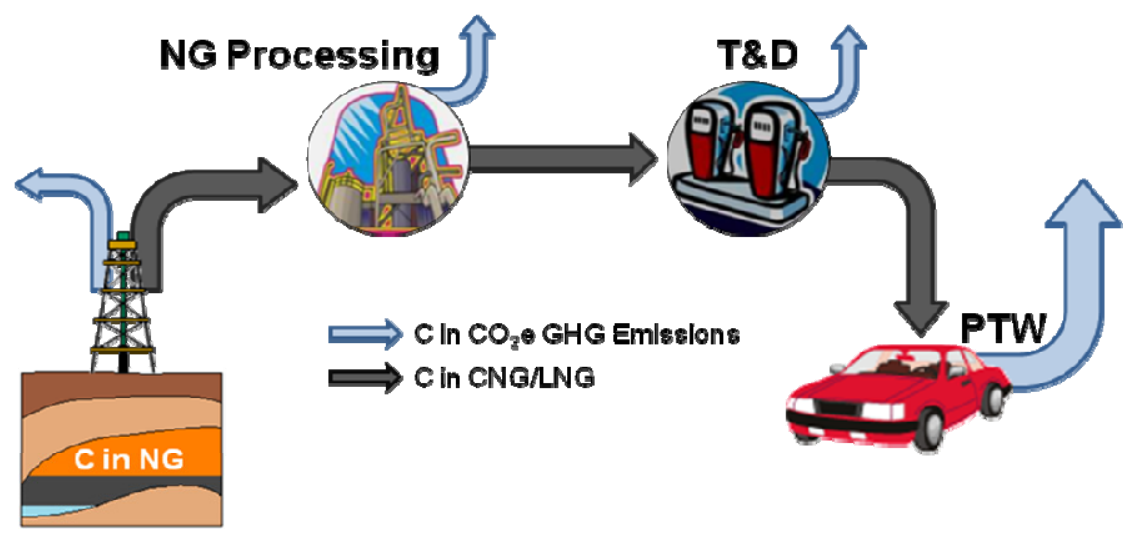

FIGURE $9 \mathrm{CO}_{2}$ Emissions in Fossil NG-to-CNG/LNG Fuel Cycle

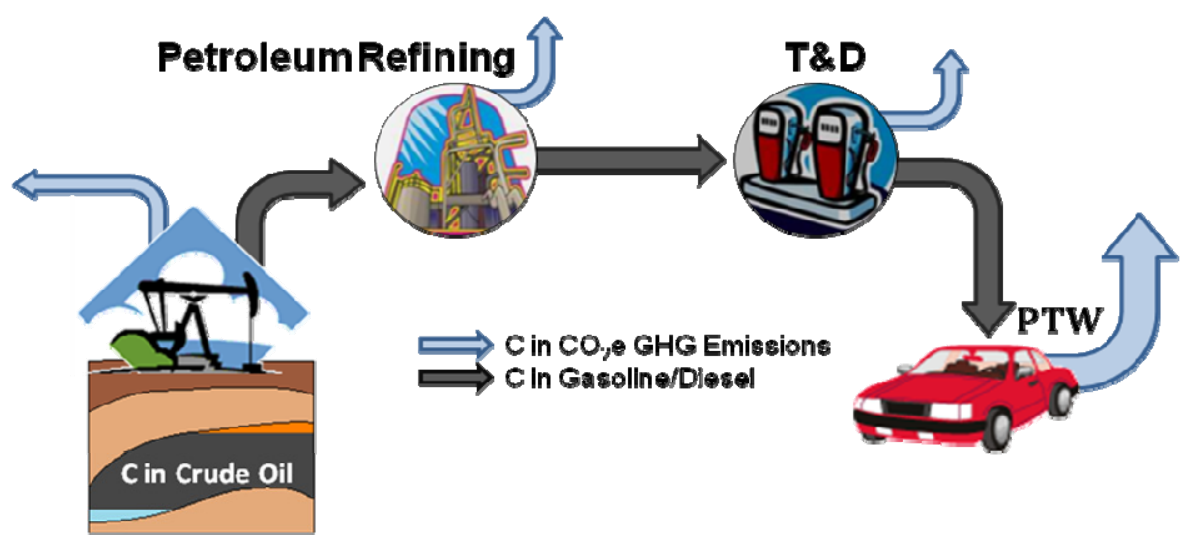

FIGURE $10 \mathrm{CO}_{2}$ Emissions in Petroleum Gasoline/Diesel Fuel Cycle 


\subsection{OVERVIEW OF LFG-TO-CNG/LNG FUEL CYCLE}

Figure 6 illustrates the 10 LFG-based pathways investigated in this study. Shown within the dashed system boundary, pathways include the resource - LFG collected by the gas collection system (discussed in Section 3.3); a cleanup/purification process to convert it into NG (discussed in Section 3.4); electricity from either an on-site generator or the grid, assuming the U.S. average generation mix (discussed in Section 3.5); and, if fueling is off-site, pipeline or truck delivery of the product NG to stations where it is compressed for vehicle fueling. For pathways in which LNG is produced, a liquefaction process (discussed in Section 3.6) occurs between production and transportation and distribution (T\&D, which is discussed in Section 3.7). Note that this fuel cycle is but a portion of the lifecycle of municipal solid waste.

Table 3 summarizes the assumptions of each pathway. The collected LFG is converted to $\mathrm{NG}$ via pre-purification and $\mathrm{CO}_{2}$ removal. The NG production process usually requires electricity as a process fuel that can be delivered by an on-site distributed generator (RC-1, RC-2, RL-1, RL-2, and RL-3) or from the grid (RC-3, RC-4, RL-4, RL-5, and RL-6). During NG processing, waste gases (including contaminants, $\mathrm{CO}_{2}$, and unrecovered $\mathrm{CH}_{4}$ ) may be returned to the input stream or flared. Since the waste gases are not involved in NG processing (i.e., they essentially flow through the process), they are subtracted from the LFG feed for modeling purposes. Thus, in all GREET-modeled pathways, the LFG feed is assumed to include only $\mathrm{CH}_{4}$ converted into NG or used for on-site power generation.

TABLE 3 Assumptions for LFG-Based CNG/LNG, Fossil CNG/LNG, and Petroleum Pathways

\begin{tabular}{cccccc}
\hline $\begin{array}{c}\text { Case } \\
\text { No. }\end{array}$ & Feedstock & Fuel & Electricity Source & Fueling & $\begin{array}{c}\text { Transportation \& } \\
\text { Distribution (T\&D) }\end{array}$ \\
\hline RC-1 & LFG & CNG & Site Generation & On-site & N/A \\
RC-2 & LFG & CNG & Site Generation & Off-site & Pipeline \\
RC-3 & LFG & CNG & U.S. Average Mix & On-site & N/A \\
RC-4 & LFG & CNG & U.S. Average Mix & Off-site & Pipeline \\
CNG & NA NG & CNG & U.S. Average Mix & Off-site & Pipeline \\
CG & Crude & Gasoline & U.S. Average Mix & Off-site & Mixed Mode \\
RL-1 & LFG & LNG & Site Generation & On-site & N/A \\
RL-2 & LFG & LNG & Site Generation & Off-site & LNG Truck \\
RL-3 & LFG & LNG & Site Generation & Off-site & Diesel Truck \\
RL-4 & LFG & LNG & U.S. Average Mix & On-site & N/A \\
RL-5 & LFG & LNG & U.S. Average Mix & Off-site & LNG Truck \\
RL-6 & LFG & LNG & U.S. Average Mix & Off-site & Diesel Truck \\
LNG & NA NG & LNG & U.S. Average Mix & Off-site & Pipeline \\
LSD & Crude & Diesel & U.S. Average Mix & Off-site & Mixed Mode \\
\hline
\end{tabular}


For renewable $\mathrm{CNG}$ (RC cases in Figure 6), the produced gas is compressed by an electric compressor at a fuel station. For on-site fueling cases (RC-1 and $\mathrm{RC}-3$ ), the necessary electricity is supplied by the genset; for off-site fueling cases (RC-2 and RC-4), electricity comes from the grid. For renewable LNG (RL cases in Figure 6), the produced gas is liquefied by a small, on-site liquefier. NG production and liquefaction use the same power source (i.e., a distributed generator for RL-1, RL-2, and RL-3 and the grid for RL-4, RL-5, and RL-6). The produced liquid can be dispensed at an on-site fuel station (RL-1 and RL-4) or transported to offsite stations via LNG trucks (RL-2 and RL-5) or diesel trucks (RL-3 and RL-6). Note that LNG trucks are fueled by the LFG-based LNG.

In this study, energy and material inputs and outputs are characterized for the steps in the LFG-to-CNG and LFG-to-LNG fuel cycles in order to estimate overall energy and greenhouse gas emissions associated with pathways. As with other GREET pathways, results for LFG-based $\mathrm{CNG}$ and LNG are estimated in units of energy use and emissions per unit of consumed energy and/or per mile driven with vehicles fueled with CNG/LNG. For "well-to-pump" (WTP) results, this includes NG production, transmission, and distribution of the fuels; for "well-to-wheels" (WTW) results, it includes WTP results plus consumption or emissions during vehicle operation. Estimates are then compared with results for fossil North American natural gas (NA NG) and conventional petroleum pathways.

Note that conventional NA NG and petroleum pathways start with energy in the unrecovered feedstock, while the landfill gas pathway starts with energy in the collected feedstock (i.e., LFG). As pointed out in Brinkman et al. (2005), the GREET model accounts for energy use at different starting points for different fuels. For fossil fuels — such as NA NG, gasoline, diesel, and electricity from fossil fuels - the accounting system starts with primary feedstock recovery. In this study, the energy in the collected LFG is not of concern because it would have been flared if not converted to NG. Therefore, landfill gas pathways start with the processing of collected LFG. Details about the energy accounting are discussed in Section 3.4.4.

\subsection{GAS COLLECTION}

As stated earlier, pathways begin with a process stream of LFG, which is assumed to be $75 \%$ of the total LFG produced (Figure 6). While this share is consistent with EPA assumptions, it is not a critical parameter. ${ }^{8}$ Instead of going to the flare, a blower diverts the collected LFG to a cleanup unit.

\subsection{NATURAL GAS PRODUCTION}

The NG production process includes pre-purification and purification (primarily $\mathrm{CO}_{2}$ removal). The processes can use similar technologies and are closely integrated in many cases. Also, the required process energy or process efficiency is often reported as an integrated process.

${ }^{8}$ Others claim that the average share of LFG collected is closer to $90 \%$ (Sullivan 2010). However, because GREET pathways begin with the processing of collected LFG, the share lies outside our fuel cycle system boundary and does not affect results. 
Therefore, NG production efficiency in this study is defined as the energy in the produced NG divided by the sum of the energy in the LFG fed to the pre-purification step plus the process electricity for pre-purification and $\mathrm{CO}_{2}$ removal.

\subsubsection{Pre-Purification}

The collected landfill gas must be treated to remove impurities before it enters the $\mathrm{CO}_{2}$ removal process. Impurities include corrosive hydrogen compounds, low concentrations (parts per million) of non-methane organic compounds (NMOCs, including siloxane), and water. As stated in 40 CFR Parts 72 and 75, the level of hydrogen sulfide $\left(\mathrm{H}_{2} \mathrm{~S}\right)$ - a corrosive, toxic, and flammable gas with unpleasant odor - must be reduced to less than $5 \mathrm{ppm}$ (or $0.3 \mathrm{~g} / 100 \mathrm{scf}$ ) for pipeline natural gas. Many well-established processes (e.g., absorption, adsorption, and chemical and thermal oxidation) ${ }^{9}$ are available for $\mathrm{H}_{2} \mathrm{~S}$ removal from gas fluxes (Syed et al. 2006). One of the most common is an iron oxide-based sulfur scavenging process (Kohl and Nielsen 1997) in which hydrogen sulfide reacts with iron oxide to form iron sulfide while the landfill gas flows through granular iron-oxide in a bed. The process is suitable for the treatment of relatively small volumes of gas. For dehydration, pressure swing adsorption (PSA) or refrigerated drying are widely used.

The output - pre-purified landfill gas — can then be used to fuel an on-site powergenerator, providing electricity for $\mathrm{CO}_{2}$ removal and further conditioning steps, as well as export power.

\subsection{2 $\mathrm{CO}_{2}$ Removal}

The $\mathrm{H}_{2} \mathrm{~S}$-treated and dehydrated landfill gas is further purified by removing $\mathrm{CO}_{2}$ from the gas stream. Four types of technologies are widely employed: membrane separation, adsorption, absorption, and cryogenic distillation. To enhance the quality of the product fuel, more than one technology may be used in series. Further details are explained below.

\section{Membrane Separation}

Since $\mathrm{CO}_{2}$ is more permeable than $\mathrm{CH}_{4}$, the two may be separated by selective permeation through membranes. When the landfill gas contacts the membrane, more $\mathrm{CO}_{2}$ than $\mathrm{CH}_{4}$ permeates, although quantities depend on the partial pressure difference across the membrane. As shown in Figure 11, $\mathrm{CO}_{2}$ concentration in the LFG feed affects the optimum number of membrane stages (Spillman 1995, Datta and Sen 2006). Since two-stage and threestage membrane systems are more economical (in dollars per normal $\mathrm{m}^{3}$ of product gas) than single-stage systems, a second membrane system or a secondary amine process is often used in landfill gas projects (Pomerantz and Turcotte 2004).

9 These same technologies are used in large-scale NG processing plants, but with somewhat different sulfur scavenging processes. 


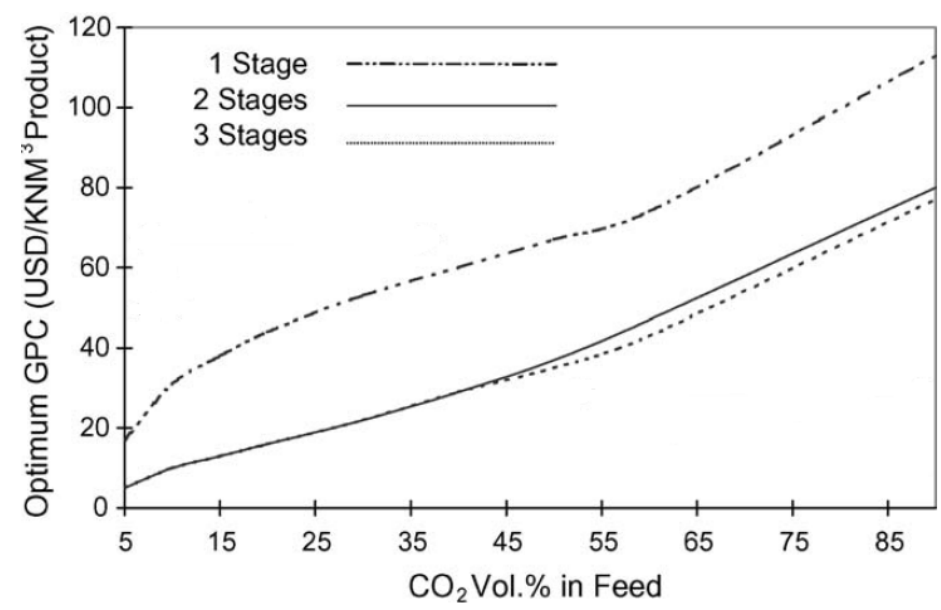

FIGURE 11 Gas Processing Cost (GPC) Associated with 1-, 2-, and 3-Stage Membranes (Datta and Sen 2006)

Membrane separation is amenable to a wide range of process stream volumes, $\mathrm{CO}_{2}$ concentrations and product-gas specifications. It also tends to be more environmentally friendly than amine processes. Since membrane separation operates at relatively high pressure, ranging from 200 to 600 psig (Air Liquide 2009, Pomerantz and Turcotte 2004), a further benefit is reduction in compression requirements for $\mathrm{CNG}$ production or injection into the gas grid.

\section{Adsorption}

Swing adsorption separates $\mathrm{CO}_{2}$ from landfill gas by collecting $\mathrm{CO}_{2}$ on the surface of an adsorbent. Parameters affecting the collection include temperature, total pressure, and partial pressure of the constituent gases. In pressure swing adsorption (PSA), the pressure is swung (since $\mathrm{CO}_{2}$ is adsorbed more easily than $\mathrm{CH}_{4}$ under high pressure) and the $\mathrm{CH}_{4}$-rich gas that is not adsorbed flows through the vessel. Once the adsorbent in the vessel is saturated, adsorbed $\mathrm{CO}_{2}$ is removed by reducing the pressure to ambient. A cycle of PSA adsorption and desorption is typically relatively short since common industrial practice is to use multiple vessels to maintain a constant feed flow and output gas product. PSA operates at relatively high pressure; the pressure of the product gas ranges from 100 to 200 psig (Sperling Hansen Assoc. 2007).

\section{Absorption}

In absorption processes, molecules in gas phase (e.g., $\mathrm{H}_{2} \mathrm{~S}$ and $\mathrm{CO}_{2}$ ) are removed as they become liquid phase in solutions. The amine process, one of the most common absorption processes in the natural gas industry, uses aqueous solutions of various alkanolamines to remove $\mathrm{H}_{2} \mathrm{~S}$ and $\mathrm{CO}_{2}$. In a typical process, a $\mathrm{CO}_{2}$ - and $\mathrm{H}_{2} \mathrm{~S}$-rich gas passing upward through an absorber contacts a downward-flowing amine solution that absorbs $\mathrm{CO}_{2}$ and $\mathrm{H}_{2} \mathrm{~S}$. The purified gas flows through to the top of the absorber, while the amine-rich gas is collected at the bottom where it is sent to a regenerator to produce lean amine. In some landfill gas recovery projects, water scrubbing (i.e., water is the absorbent) is used in place of an amine solution. 


\section{Cryogenic Distillation}

Cryogenic distillation uses the relatively higher boiling temperature of $\mathrm{CO}_{2}$ - as compared with $\mathrm{CH}_{4}-$ to separate it from landfill gas. $\mathrm{CO}_{2}$ Wash $\AA$, developed by Acrion Technologies, illustrates the cryogenic distillation process. ${ }^{10}$ As in the amine process, dry compressed landfill gas enters the bottom of an absorber column, flows upward, and contacts a downwardflowing solution (in this case, liquid $\mathrm{CO}_{2}$ ), which "washes" out contaminants (see Figure 12). When the contaminant-free landfill gas is cooled by refrigeration at the top of the absorber (typical gas temperature is $-59^{\circ} \mathrm{F}$ ), the $\mathrm{CO}_{2}$ in the gas is condensed. The clean gas exits at the top of the absorber, and some of the liquid $\mathrm{CO}_{2}$ can be collected for possible co-product use. The rest of the

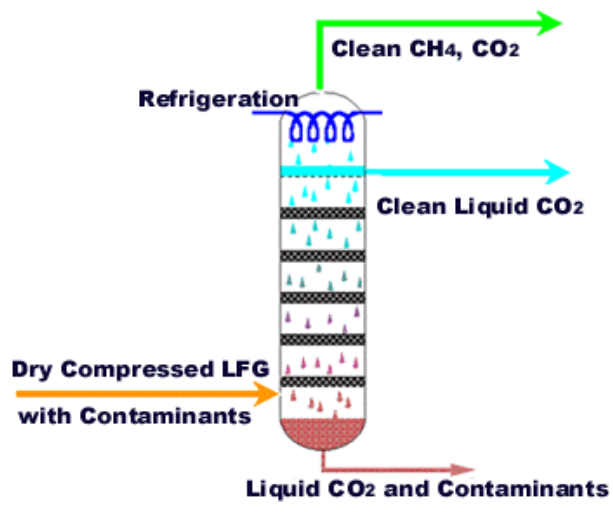

FIGURE $12 \mathrm{CO}_{2}$ Wash ${ }^{\circledR}$ Process (Acrion 2009) $\mathrm{CO}_{2}$ flows downward as the absorbent. The contaminant-free gas is clean enough to provide a hydrogen source for a fuel cell or a feedstock for chemical synthesis, such as methanol. However, since its $\mathrm{CO}_{2}$ concentration $(\sim 27 \%)$ is still higher than pipeline quality natural gas or transportation fuel, further treatment or post purification (for example, using membrane separation) is required (Cook et al. 2005).

\subsubsection{Process Efficiency}

Data to develop the NG production process efficiency were obtained by literature search and direct contact with developers of a number of pilot- and commercial-scale LFG-to-NG projects whose information is publicly available. These include Acrion 2009, Cook 1998, Cook 2002, Prometheus 2007, Sperling Hansen Assoc. 2007, Pomerantz and Turcotte 2004, GTI 2007, and Johansson 2008. As shown in Figure 13, the energy efficiency of NG processing at these sites ranges from about $91 \%$ to $97 \%$, with larger projects tending to achieve somewhat higher efficiency. Although most projects generate their own electricity for NG processing, two projects do not report the amount of LFG used for on-site power generation and none report the share of co-generated electricity exported to the grid. Thus, all co-generated electricity is assumed to be used for NG production, and NG processing efficiency is calculated from the energy content of the landfill gas used, assumed liquefaction efficiency (see Section 3.6), and assumed generator efficiency (ranging from approximately $28 \%$ to $44 \%$ ). On the basis of these data and assumptions, the default NG processing efficiency is calculated as $94.4 \%$.

\footnotetext{
${ }^{10}$ A key advantage of $\mathrm{CO}_{2}$ Wash ${ }^{\circledR}$ is that it uses liquid $\mathrm{CO}_{2}$ separated from landfill gas to absorb other impurities.
} 


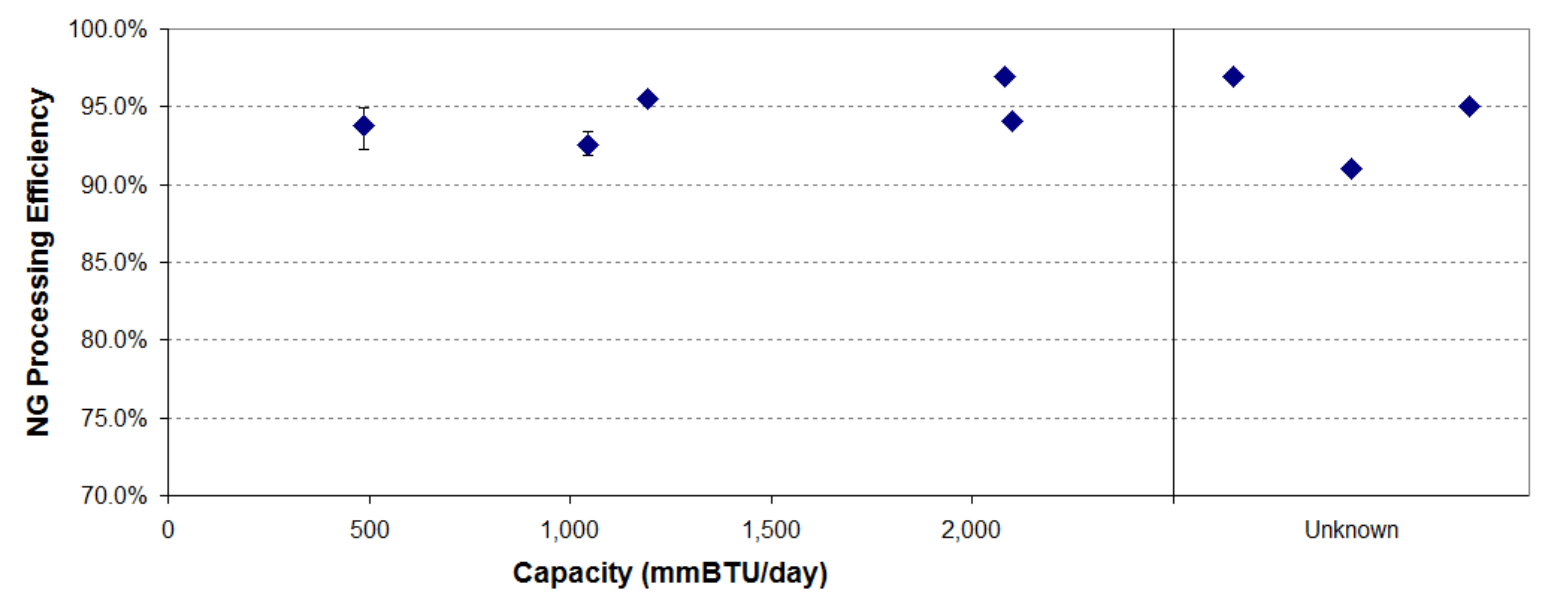

FIGURE 13 NG Processing Efficiencies of LFG-Based Projects Producing Vehicle Fuel

\subsubsection{Energy Use Accounting}

Although LFG-based CNG/LNG contains the same amount of energy as fossil-based $\mathrm{CNG} / \mathrm{LNG}$, the former is renewable (ultimately from solar energy), while the latter is not. This highlights a key issue in GREET simulation of LFG-based pathways - namely, the appropriate treatment of the energy in LFG. This energy is produced from the decomposition of organic materials by methanogenic bacteria in the waste stream. From the point of view of energy accounting, the "system" includes only the solar energy recovered from the organic materials, since the losses from solar energy to organic material and from organic material to LFG are irrelevant. As with other biogenic energy sources, the solar energy embedded in LFG can be ignored since it would be unused if not captured. Thus, the LFG fuel cycle includes only the energy in the LFG (as total energy but not fossil fuel) when it is used to generate power for processing (or for addition to the grid), for compression/liquefaction and T\&D, and for vehicle operation. However, if the amount of co-generated electricity equals the amount of process electricity required (for LFG processing and compression or liquefaction) or the plant does not import or export electricity, only the energy used by the genset or converted to NG needs to be counted. On the other hand, if the generator produces less electricity than needed for processing, the remainder must be imported from the grid and upstream energy use and emissions for imported grid electricity must be included in the fuel cycle analysis. Likewise, if the amount of co-generated electricity exceeds process needs, the excess can be sold to the grid (displacing an equivalent amount of electricity) and upstream energy and emissions (for the displaced grid electricity) must be taken as credits. ${ }^{11}$

\subsection{ON-SITE POWER GENERATION}

Many landfill gas recovery projects incorporate on-site generators to produce process electricity. Established technologies include internal combustion engines (ICEs) and natural gas turbines.

\footnotetext{
${ }^{11}$ For LFG-based CNG/LNG pathways, we assume that the genset generates the same amount of electricity as the amount of process electricity required, meaning no electricity is imported or exported.
} 


\subsubsection{Technologies}

ICEs are typically spark-ignition reciprocating engines powered by the pre-purified landfill gas (or biogas). ICEs offer low initial cost, easy start-up, proven reliability, and good part-load characteristics and heat recovery potential. Emissions can be controlled by exhaust catalysts, selective catalytic reduction, and better control of the combustion process. NREL and EPRI forecast electric efficiencies for natural gas ICEs ranging from 33\% for rich-burn engines to $44 \%$ for lean-burn engines by 2010 (Goldstein et al. 2003, EPRI 2004).

Combustion turbines can develop power over a wide capacity range, from several kilowatts to hundreds of megawatts. Microturbines, small combustion turbines with outputs in the range of 30-200 kW, are suited to lower-capacity applications like LFG recovery. Microturbines (MTs) are capable of producing power at improved efficiencies by recuperating heat from the exhaust gas to the incoming air stream. They also have the advantage of no gearbox or lubricating oil requirement and high engine speed (ranging from 80,000 to $100,000 \mathrm{rpm}$ ) (Dunn 2000). NREL and EPRI forecast microturbine and small gas turbine efficiencies of $29-40 \%$ by 2010 (Goldstein et al. 2003, EPRI 2004).

\subsubsection{Criteria Pollutant Emissions}

Since all but one of the landfill gas projects reviewed in this study use ICEs for on-site power generation, and emissions data are more generally available for LFG-fueled ICEs than for MTs, ICE engines are the default technology for LFG-fueled power generation in GREET. On the basis of available data, their default electric efficiency (electricity from the genset divided by energy in the LFG feed to the genset) is set to $35 \%$.

Since it is assumed that electricity is the only energy source used in the process (other than the LFG itself), emissions from power generation are the only emissions that need be taken into account in the fuel cycle analysis. These are calculated from newly developed GREET emission factors for LFG-fueled stationary IC engines. Most current projects producing pipelinequality gas or $\mathrm{CNG} / \mathrm{LNG}$ for vehicle fuel utilize IC engines in the range of 1-2 MW that must meet point source standards for criteria pollutant emissions. Since local rules are often stricter than federal standards, GREET emission factors are based on the former, calculated from project-level data contained in permit applications and source tests. Default factors for emissions of volatile organic compounds (VOCs), carbon monoxide $(\mathrm{CO})$, nitrogen oxides $\left(\mathrm{NO}_{\mathrm{x}}\right)$, and particulates of 10 micrometers or more $\left(\mathrm{PM}_{10}\right)$ are calculated from these data. Methane $\left(\mathrm{CH}_{4}\right)$ and nitrous oxide $\left(\mathrm{N}_{2} \mathrm{O}\right)$ emissions are rarely reported in source tests since they are not regulated. ${ }^{12}$ Moreover, field measurements of $\mathrm{N}_{2} \mathrm{O}$ are generally below detection limits. Thus, GREET emission factors for unburned methane (i.e., $\mathrm{CH}_{4}$ slip) from the $\mathrm{IC}$ engine are based on the relative methane destruction efficiency of stationary IC engines as compared with the flare. GREET default emission factors for carbon dioxide $\left(\mathrm{CO}_{2}\right)$ and sulfur oxide $\left(\mathrm{SO}_{\mathrm{x}}\right)$ from on-site power generation are estimated as a function of genset efficiencies, the carbon and sulfur content of input and output gas streams, and values reported in the literature.

\footnotetext{
${ }^{12}$ Although $\mathrm{CH}_{4}$ could be calculated as the difference between total $\mathrm{HC}$ and $\mathrm{NMHC}$, the result is not accurate because the methodologies are not consistent.
} 
TABLE 4 Emission Factors for LFG-Fueled IC Engines, LFG Flares, and U.S. Power Generation

\begin{tabular}{lrrrrrrrrr}
\hline \multicolumn{1}{c}{ Factor $(\mathrm{g} / \mathrm{mmBtu})$} & $\mathrm{VOC}$ & $\mathrm{CO}$ & $\mathrm{NO}_{\mathrm{x}}$ & $\mathrm{PM}_{10}$ & $\mathrm{PM}_{2.5}$ & $\mathrm{SO}_{\mathrm{x}}$ & $\mathrm{CH}_{4}$ & $\mathrm{~N}_{2} \mathrm{O}$ & $\mathrm{CO}_{2}$ \\
\hline & & & & & & & & & \\
LFG-Fueled ICEs & 62.7 & 273.5 & 20.1 & 8.5 & 8.5 & 0.27 & 446 & 0.87 & 57,600 \\
LFG Flares & 23.7 & 41.5 & 16.2 & 5.0 & 5.0 & 0.27 & 31.6 & 1.1 & 59,200 \\
U.S. Average Power & 3.4 & 45.5 & 187 & 13.0 & 7.0 & 474 & 3.8 & 2.67 & 207,000 \\
Generation & & & & & & & & & \\
\hline
\end{tabular}

Since LFG is assumed to be flared unless used in the generator or converted to NG, avoided emissions (from the flare) are considered credits. Emission factors for VOC, $\mathrm{CO}, \mathrm{NO}_{\mathrm{x}}$, and $\mathrm{PM}_{10}$ from LFG flares are used to calculate these credits (EPA 1995). As stated above, $\mathrm{CH}_{4}$ emission factors are calculated from the destruction efficiency of LFG flares $(99.86 \%$ ) (SCS 2007, TRC Environmental Corporation 2008), while $\mathrm{CO}_{2}$ and $\mathrm{SO}_{\mathrm{x}}$ emission factors are calculated by using a carbon and sulfur balance approach.

Table 4 summarizes the emission factors for LFG-fueled IC engines and LFG flares as compared to those for U.S. power generation (i.e., the average emission factor for the mix of technologies used for electricity production). Note that upstream emissions of the U.S. average mix are substantial (15.5 g VOC/MMBtu, $37.6 \mathrm{~g} \mathrm{NO}_{\mathrm{x}} / \mathrm{MMBtu}, 274 \mathrm{~g} \mathrm{PM} \mathrm{PM}_{10} / \mathrm{MMBtu}, 68.5 \mathrm{~g}$ $\mathrm{PM}_{2.5} / \mathrm{MMBtu}$, and $283 \mathrm{~g} \mathrm{CH}_{4} / \mathrm{MMBtu}$ ), while LFG produces no upstream emissions.

\subsection{LIQUEFACTION}

For LNG production, the clean gas is liquefied at the recovery site for both on-site and off-site fueling pathways. Clean gas is cooled to $-260^{\circ} \mathrm{F}$, and, if necessary, a post-purification step is used to further enhance the quality of LNG. This is usually accomplished by flash evaporation of nitrogen. Produced LNG is stored on-site as a cryogenic liquid in insulated storage vessels at $50-150$ psi.

Efficiency is the primary determinant of energy use and emissions associated with NG liquefaction. Efficiency data for several technologies of interest to this analysis are summarized in Table 5. According to Brendeng and Hetland (2004), the propane pre-cooled mixed refrigerant (C3/MR) process accounts for nearly $80 \%$ of large-scale liquefaction units and almost $90 \%$ of global capacity. Although representing a smaller share of global capacity, the single mixed refrigerant (SMR) and expander processes are considered good candidates for small-scale liquefaction and are already used in some LFG projects (Cook et al. 2005, GTI 2007, Prometheus Energy Corp. 2007). In this study, SMR and expander processes are assumed to be representative of small-scale liquefaction, and thus the default NG liquefaction efficiency is set to $89 \%$, which is relatively lower than the large-scale efficiency assumption (91\%) used elsewhere in GREET. Appendix A contains a more detailed discussion of the liquefaction calculations and assumptions used in this analysis. 
TABLE 5 Plant Efficiencies of NG Liquefaction Technologies (Vink and Nagelvoort 1998)

\begin{tabular}{|c|c|c|c|c|c|}
\hline Technology & $\mathrm{C} 3 / \mathrm{MR}^{\mathrm{a}}$ & Cascade & $\mathrm{DMR}^{\mathrm{b}}$ & $\mathrm{SMR}^{\mathrm{c}}$ & Expander \\
\hline Plant Efficiency (\%) & 90.7 & 89.0 & 90.5 & 89.4 & 88.2 \\
\hline
\end{tabular}

\subsection{TRANSPORTATION AND DISTRIBUTION}

As mentioned earlier, the produced $\mathrm{CNG} / \mathrm{LNG}$ can be dispensed at an on-site fuel station or transported to off-site fuel stations via pipeline (if CNG) or heavy-duty truck (if LNG). For off-site fueling, GREET default assumptions are used to calculate feedstock loss and transport energy consumption, but transport distance is reduced to 50 miles.

\subsubsection{Transportation and Distribution of CNG}

Assuming that the pressure of the produced NG is high enough to be directly injected into a local distribution system (200 psig), no addition energy consumption or emissions are considered for both on-site and off-site CNG cases other than those in conjunction with dispensing into a CNG-fueled vehicle. At fuel stations, the produced $\mathrm{NG}$ is compressed to 4,000 psia by electric compressors. The electric compressors at an on-site station are assumed to use electricity supplied by the on-site LFG-fueled generator, while those at off-site stations are powered by grid electricity. Compression efficiency, defined as the heating value of the compressed gas divided by the sum of energy used during NG compression and the heating value of the compressed gas, is calculated from the following formula based on an adiabatic process (Wang et al. 2001):

$$
\begin{gathered}
W_{\min }=N \times \frac{k}{k-1} \times M \times R \times T \times Z\left(\left(\frac{P_{2}}{P_{1}}\right)^{\frac{k-1}{N k}}-1\right), \\
\text { Compression Efficiency } \\
=\frac{F D}{\frac{W_{\min }}{C E \times}+} \\
E E
\end{gathered}
$$

where:

$$
\begin{array}{ll}
W_{\min } & =\text { minimum work required for gas compression }(\mathrm{W}), \\
N & =\text { number of compression stages }(6 \text { for off-site; } 5 \text { for on-site fuel stations }), \\
k & =\text { ratio of specific heats }(1.32 \text { for } \mathrm{NG}) \\
M & =\text { mass flow }(\mathrm{kg} / \mathrm{s})
\end{array}
$$




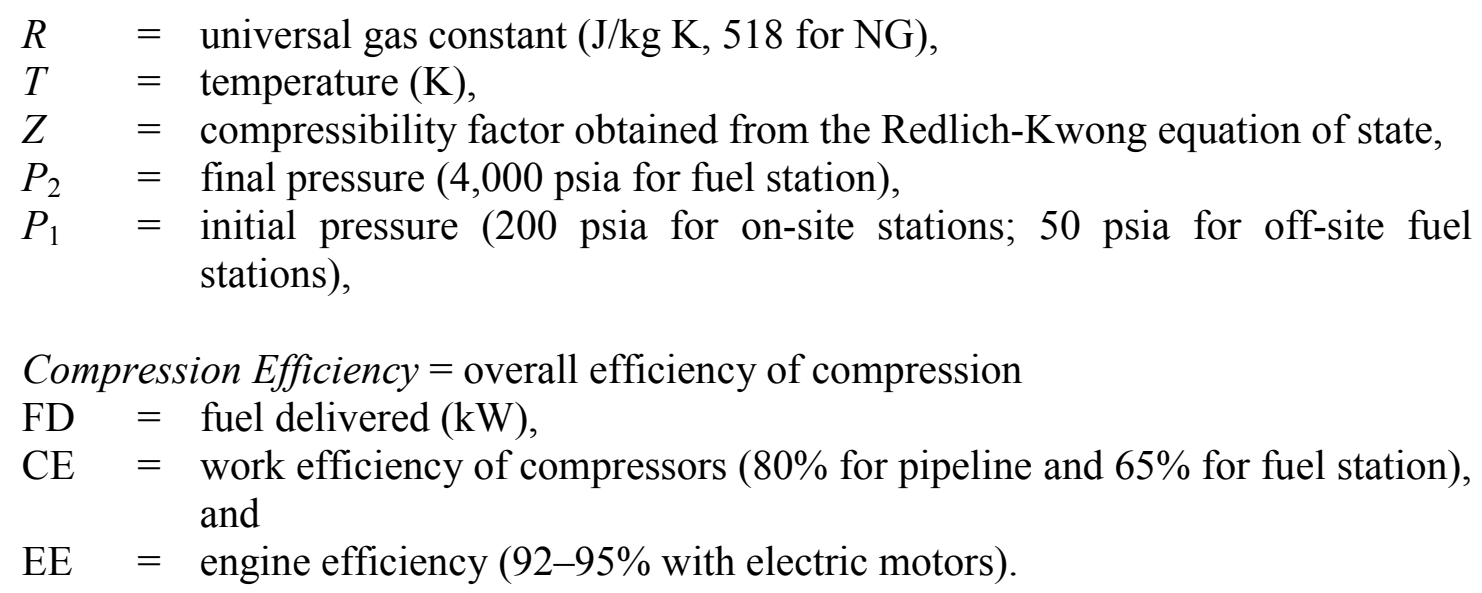

\subsubsection{Transportation and Distribution of LNG}

As mentioned earlier, LNG can be dispensed at an on-site fuel station or transported to off-site fuel stations via cryogenic tank truck. Trucks are assumed to be fueled by either LFGbased LNG from the plant or petroleum diesel. If LFG-based LNG is used, the direct NG consumption is excluded from fossil fuel accounting but not total energy accounting since the produced LNG is a renewable fuel. Also, avoided emissions (from the flare) due to the LFGbased LNG use are considered credits.

\subsection{VEHICLE OPERATION}

Fuel economy is essential for estimating fuel cycle results per mile traveled. In this study, we assume that light-duty vehicles (LDVs) operate on CNG, while heavy-duty vehicles (HDVs, especially refuse trucks) operate on LNG. Thus, results for CNG- and LNG-fueled vehicles are compared to those for conventional gasoline (CG) LDVs and diesel (CD) HDVs, respectively. We also assume that CG LDVs achieve the GREET default fuel economy and emissions, and that CNG LDVs are as efficient as CG LDVs.

On the other hand, LFG-based LNG is expected to fuel buses and refuse trucks. The latter application is particularly appealing since vehicles could be fueled on-site in the course of their normal duty cycle. As with LDVs, results for a "per mile traveled" metric require estimating the fuel economy of diesel- and LNG-fueled HDVs. Refuse truck fuel economy is reported in only a few publications. According to Chandler et al. (2001), the fuel economy of diesel-fueled refuse trucks is $2.57 \mathrm{mpg}$. Transit bus fuel economy is more readily available. According to Watt (2000), Chandler et al. (2000), Chandler et al. (2006), and Barnitt et al. (2006), current dieselfueled transit buses are $20 \%$ more fuel efficient than CNG/LNG-fueled buses. However, this advantage is likely to drop as manufacturers equip new diesel buses with particulate traps and other controls in order to meet stiff 2010 emissions standards. Cummins-Westport's new ISL G line of natural gas engines is already achieving fuel efficiencies that more closely mirror diesel fuel efficiencies (CWI 2009). For this study, we assume that diesel-fueled HDVs will be $10 \%$ more fuel-efficient than LNG-fueled HDVs. 
HDV emission factors for $\mathrm{CO}, \mathrm{PM}$, and $\mathrm{NO}_{\mathrm{x}}$ are based on EPA's engine certification data for Cummins ISL $\mathrm{G}$ engines (EPA 2010b), converted to $\mathrm{g} / \mathrm{mi}$ by using conversion factors and brake specific fuel consumption (BSFC) for heavy-duty vehicles provided by ARCADIS Geraghry \& Miller Inc. (2002). Since hydrocarbon emissions (including $\mathrm{CH}_{4}$ and VOC) are below detection limits in the certification data base, emission factors for these pollutants are set to zero. $\mathrm{N}_{2} \mathrm{O}$ emission factors are based on existing GREET defaults, while $\mathrm{SO}_{\mathrm{x}}$ and $\mathrm{CO}_{2}$ emissions are estimated from carbon and sulfur balance calculations. Table 6 summarizes the resulting emission factors for diesel- and LNG-fueled heavy-duty trucks.

TABLE 6 Emission Factors for Diesel- and LNG-Fueled Heavy-Duty Trucks

\begin{tabular}{lcccccccccc}
\hline & \multicolumn{8}{c}{ Emissions, by Pollutant $(\mathrm{g} / \mathrm{mi})$} \\
\cline { 2 - 10 } Fuel & VOC & $\mathrm{CO}$ & $\mathrm{NO}_{\mathrm{x}}$ & $\mathrm{PM}_{10}$ & $\mathrm{PM}_{2.5}$ & $\mathrm{SO}_{\mathrm{x}}$ & $\mathrm{CH}_{4}$ & $\mathrm{~N}_{2} \mathrm{O}$ & $\mathrm{CO}_{2}$ \\
\hline & & & & & & & & & \\
Diesel & 0 & 0.08 & 1.66 & 0.007 & 0.007 & 0.024 & 0 & 0.10 & 3,533 \\
LNG & 0 & 66.0 & 1.05 & 0 & 0 & 0 & 0 & 0.09 & 2,857 \\
\hline
\end{tabular}




\section{RESULTS AND DISCUSSION}

Total energy, fossil energy, criteria pollutant emissions, and greenhouse gas emissions for 10 LFG-based pathways have been added to the GREET model. WTW results are discussed below.

\subsection{ENERGY AND GREENHOUSE GAS EMISSION RATES}

Total energy use per MMBtu of fuel consumed "at the wheel" is nearly flat for the four LFG-to-CNG-based pathways and roughly comparable to LNG from NA NG and petroleum diesel pathways. The six LFG-to-LNG pathways are roughly comparable to each other and to the petroleum gasoline pathway. CNG from NA NG has somewhat lower WTW energy use than other pathways because fossil NG processing consumes substantially less energy than either LFG-based processing or petroleum refining.

Fossil energy use and GHG emissions present a very different picture. Because vehicle operation uses renewable, LFG-based fuel, GREET results show a significant reduction in WTW fossil fuel use and GHGs for all LFG-based pathways. The largest reductions are for LFG-toCNG pathways using LFG-fueled on-site power generation. With on-site vehicle fueling (i.e., no T\&D for the produced $\mathrm{CNG}$ ), fossil fuel use is completely eliminated.

\subsubsection{WTW Energy}

Figure 14 compares well-to-pump (WTP), pump-to-wheels (PTW), and well-to-wheels (WTW) energy use for each LFG-based pathway with similar results for fossil NG (CNG from NA NG, LNG from NA NG), gasoline from conventional petroleum, and diesel from conventional petroleum. Petroleum-based pathways are shown to permit comparison with cases in which the LFG-based fuel replaces gasoline in light-duty vehicles or diesel in heavy-duty vehicles. Since LFG-based LNG could replace diesel in refuse haulers or transfer trucks, the latter case is particularly interesting to operators of landfills or fleets of waste collection vehicles.

As stated earlier, WTW total energy use (the sum of WTP and PTW bars in Figure 14) depends largely on system efficiency. Thus, landfill gas-based CNG typically requires more total energy than fossil CNG or petroleum gasoline, and LFG-based LNG requires more total energy than fossil LNG or petroleum diesel. Because compression is more energy efficient than liquefaction, LNG requires more total energy than CNG. By contrast, the choice of process fuel in NG processing or for T\&D has little effect on WTW total energy use because the difference in energy efficiency is relatively small, and total energy use is dominated by vehicle operation (PTW). 


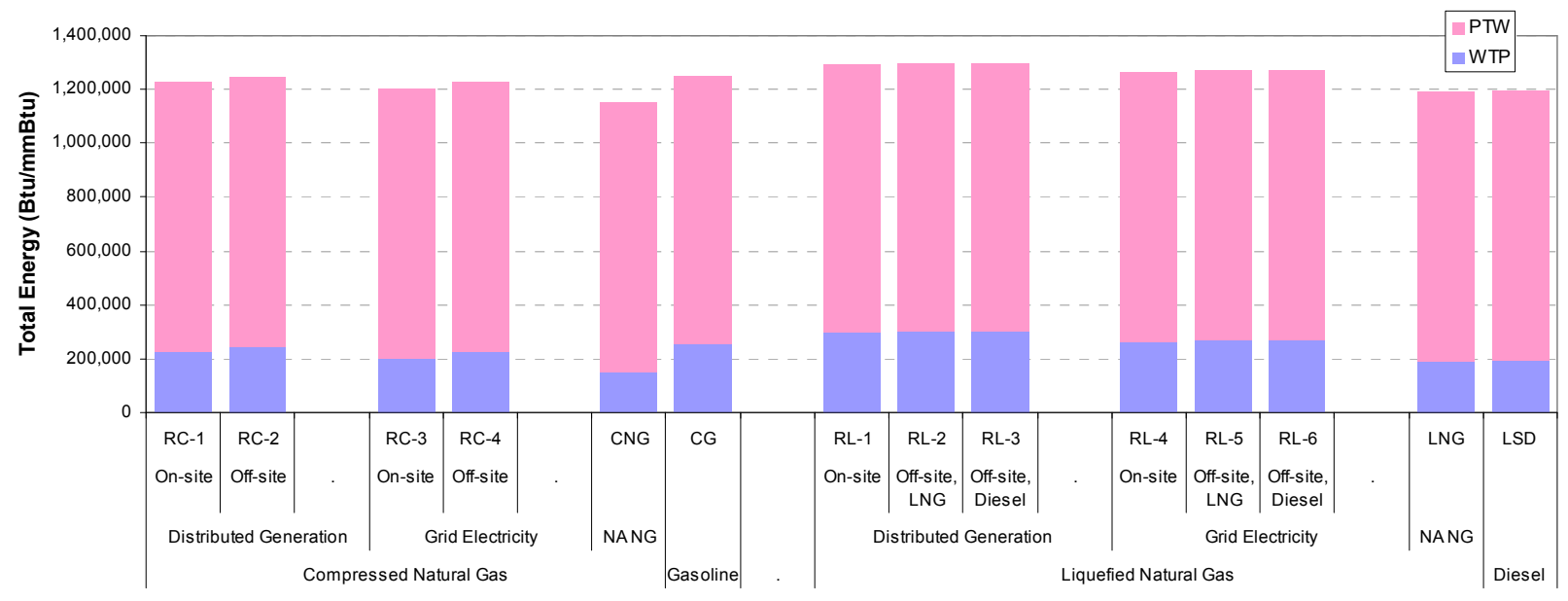

FIGURE 14 WTP, PTW, and WTW Energy Use for LFG-to-CNG/LNG Pathways versus Fossil NG-to-CNG/LNG, Gasoline, and Diesel Pathways

Table 7 displays WTW energy use by stage for LFG-to-CNG pathways. Pathways using on-site power generation (with on-site or off-site vehicle fueling) and grid electricity are shown, as are pathways for CNG from NA NG (with off-site fueling) and for petroleum gasoline. Cells corresponding to subcategories are shown without shading, while cells corresponding to subtotals for WTP and WTW energy are shaded gray. As discussed earlier, the life cycle for LFG-based fuels begins with fuel production; hence, there are no entries for feedstock recovery or feedstock transportation in Table 7. Fuel production and vehicle operation are the main energy-consuming stages. Because production of CNG from LFG is on a much smaller scale and requires more cleanup than $\mathrm{CNG}$ from $\mathrm{NA}$ NG, it uses 4-5 times the fuel production energy of CNG from NA NG. Nonetheless, production of CNG from LFG uses less energy than production of petroleum gasoline. Adding its far greater energy expenditure for T\&D (primarily for compression during vehicle fueling), CNG from LFG has comparable WTP and WTW energy use to petroleum gasoline (but not CNG from NA NG, which it exceeds by 30-35\%).

By definition, PTW (or vehicle operation) energy use has a value of 1,000,000 $(1,000,000$ fuel Btu per 1,000,000 Btu of energy use) for all pathways shown in Table 7. Since grid electricity is more energy efficient than on-site generation, fuel production with grid electricity uses approximately 10\% less energy.

Table 8 contains a comparable breakdown of WTW energy use for LFG-to-LNG, NA NG-to-LNG, and petroleum diesel pathways. Pathways using on-site power generation (with onsite or off-site vehicle fueling) and grid electricity are shown, as are pathways using LFG-based LNG or petroleum diesel for fuel T\&D. Again, feedstock recovery and transmission stages do not apply to LFG-based pathways, fuel production is the major energy expenditure, use of distributed power increases energy use, and vehicle efficiencies are set to 1,000,000. Here, however, LNG from LFG uses approximately 50\% more energy WTP than LNG from NA NG. 
TABLE 7 WTW Total Energy Use for LFG-to-CNG Pathways by Stage (Btu/MM Btu produced)

\begin{tabular}{|c|c|c|c|c|c|c|}
\hline \multirow{3}{*}{$\begin{array}{l}\text { Electricity Source } \\
\text { T\&D (Compression) }\end{array}$} & \multicolumn{4}{|c|}{ Landfill Gas-Based Compressed Natural Gas } & \multirow{3}{*}{$\begin{array}{c}\text { CNG from } \\
\text { NA NG } \\
\text { Off-Site } \\
\end{array}$} & \multirow[b]{3}{*}{ Gasoline } \\
\hline & \multicolumn{2}{|c|}{ Distributed Generation } & \multicolumn{2}{|c|}{ US Average Generation Mix } & & \\
\hline & On-Site & Off-Site & On-Site & Off-Site & & \\
\hline Feedstock Recovery & 0 & 0 & 0 & 0 & 31,398 & 42,868 \\
\hline Feedstock Transmission & 0 & 0 & 0 & 0 & 0 & 10,660 \\
\hline Fuel Production & 177,935 & 169,554 & 152,132 & 152,188 & 31,965 & 190,407 \\
\hline Fuel T\&D & 49,819 & 73,022 & 48,605 & 73,022 & 86,287 & 6,808 \\
\hline WTP & 227,754 & 242,576 & 200,737 & 225,210 & 149,651 & 250,743 \\
\hline Vehicle Operation & $1,000,000$ & $1,000,000$ & $1,000,000$ & $1,000,000$ & $1,000,000$ & $1,000,000$ \\
\hline WTW & $1,227,754$ & $1,242,576$ & $1,200,737$ & $1,225,210$ & $1,149,651$ & $1,250,743$ \\
\hline
\end{tabular}

TABLE 8 WTW Total Energy Use for LFG-to-LNG Pathways by Stage (Btu/MM Btu produced)

\begin{tabular}{|c|c|c|c|c|c|c|c|c|}
\hline \multirow{3}{*}{$\begin{array}{c}\text { Electricity Source } \\
\text { T\&D }\end{array}$} & \multicolumn{6}{|c|}{ Landfill Gas-Based Liquefied Natural Gas } & \multirow{3}{*}{$\begin{array}{l}\text { LNG from } \\
\text { NA NG } \\
\text { Off-Site: } \\
\text { Diesel }\end{array}$} & \multirow[b]{3}{*}{ Diesel } \\
\hline & \multicolumn{3}{|c|}{ Distributed Generation } & \multicolumn{3}{|c|}{ U.S. Average Generation Mix } & & \\
\hline & On-Site & $\begin{array}{l}\text { Off-Site: } \\
\text { LNG }\end{array}$ & $\begin{array}{l}\text { Off-Site: } \\
\text { Diesel }\end{array}$ & On-Site & $\begin{array}{l}\text { Off-Site: } \\
\text { LNG }\end{array}$ & $\begin{array}{c}\text { Off-Site: } \\
\text { Diesel }\end{array}$ & & \\
\hline Feedstock Recovery & 0 & 0 & 0 & 0 & 0 & 0 & 31,669 & 42,835 \\
\hline $\begin{array}{l}\text { Feedstock } \\
\text { Transmission }\end{array}$ & 0 & 0 & 0 & 0 & 0 & 0 & 961 & 10,652 \\
\hline Fuel Production & 294,643 & 293,469 & 293,469 & 264,590 & 263,412 & 263,412 & 142,338 & 133,918 \\
\hline Fuel T\&D & 0 & 6,608 & 6,137 & 0 & 6,485 & 6,137 & 14,104 & 6,313 \\
\hline WTP & 294,643 & 300,077 & 299,607 & 264,590 & 269,897 & 269,550 & 189,072 & 193,718 \\
\hline Vehicle Operation & $1,000,000$ & $1,000,000$ & $1,000,000$ & $1,000,000$ & $1,000,000$ & $1,000,000$ & $1,000,000$ & $1,000,000$ \\
\hline WTW & $1,294,643$ & $1,300,077$ & $1,299,607$ & $1,264,590$ & $1,269,897$ & $1,269,550$ & $1,189,072$ & $1,193,718$ \\
\hline
\end{tabular}

\subsubsection{WTW Fossil Energy}

Figure 15 compares WTP, PTW, and WTW fossil fuel use for each LFG-based pathway with CNG from NA NG, LNG from NA NG, gasoline from conventional petroleum, and diesel from conventional petroleum. Note that for landfill gas-based pathways, vehicle operation (PTW) requires no fossil fuels since the LFG-based fuels are renewable. Plus, if landfill gas is the feedstock, NG processing and liquefaction require little or no fossil fuel (depending on whether on-site generators or grid power are used for process needs), and only a small amount of fossil fuel is consumed during transportation and distribution, depending on T\&D method.

Table 9 displays WTW fossil fuel use by stage for LFG-to-CNG pathways. Pathways using on-site power generation (with on-site or off-site vehicle fueling) and grid electricity are shown, as are pathways for CNG from NA NG and for petroleum gasoline. As above, PTW fossil fuel use (for vehicle operation) is assigned a value of 1,000,000 $(1,000,000 \mathrm{Btu} / 1,000,000 \mathrm{Btu})$ for the $\mathrm{CNG}$-from-NA NG pathway. For the petroleum gasoline pathway, this value is reduced slightly to reflect the ethanol content of the gasoline fuel pool. For renewable pathways, fossil fuel use is zero. 


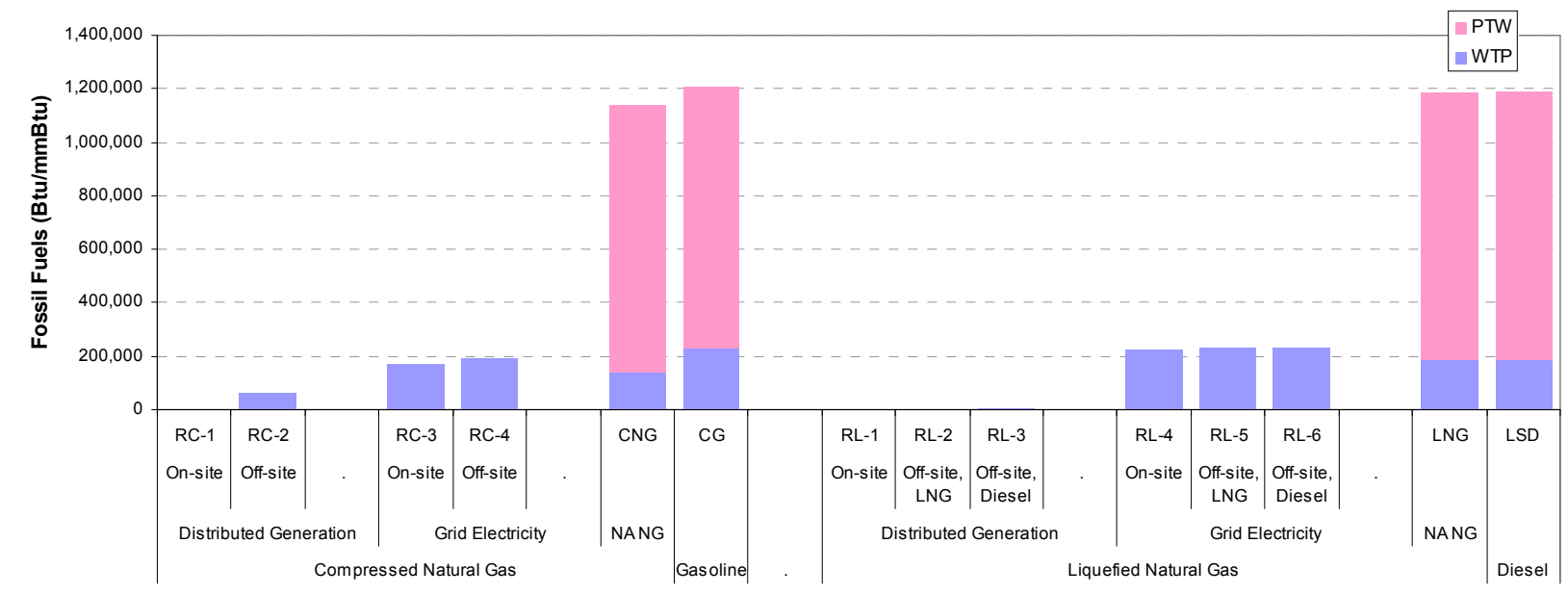

FIGURE 15 WTW Fossil Fuel Use for LFG-Based Pathways versus NA NG and Petroleum Gasoline and Diesel Pathways

TABLE 9 WTW Fossil Fuel Use for LFG-to-CNG Pathways by Stage (Btu/MM Btu produced)

\begin{tabular}{|c|c|c|c|c|c|c|}
\hline \multirow{3}{*}{$\begin{array}{c}\text { Electricity Source } \\
\text { T\&D (Compression) }\end{array}$} & \multicolumn{4}{|c|}{ Landfill Gas-Based Compressed Natural Gas } & \multirow{3}{*}{$\begin{array}{l}\text { CNG from } \\
\text { NA NG } \\
\text { Off-Site } \\
\end{array}$} & \multirow[b]{3}{*}{ Gasoline } \\
\hline & \multicolumn{2}{|c|}{ Distributed Generation } & \multicolumn{2}{|c|}{ U.S. Average Generation Mix } & & \\
\hline & On-Site & Off-Site & On-Site & Off-Site & & \\
\hline $\begin{array}{l}\text { Feedstock Recovery } \\
\text { Feedstock }\end{array}$ & 0 & 0 & 0 & 0 & 31,290 & 41,363 \\
\hline Transmission & 0 & 0 & 0 & 0 & 0 & 10,517 \\
\hline Fuel Production & 0 & 0 & 131,549 & 131,597 & 31,668 & 170,067 \\
\hline Fuel T\&D & 0 & 62,892 & 42,029 & 62,892 & 76,376 & 6,753 \\
\hline WTP & 0 & 62,892 & 173,577 & 194,489 & 139,333 & 228,700 \\
\hline Vehicle Operation & 0 & 0 & 0 & 0 & $1,000,000$ & 979,201 \\
\hline WTW & 0 & 62,892 & 173,577 & 194,489 & $1,139,333$ & $1,207,901$ \\
\hline
\end{tabular}

Depending on whether vehicle fueling is on-site or off-site, LFG-based CNG using onsite or distributed power can consume no fossil fuel WTP or about half that consumed by CNG from NA NG. On a WTW basis, LFG-based CNG can consume $0-15 \%$ of the fossil fuel consumed by petroleum gasoline.

Petroleum gasoline, petroleum diesel, and NA NG-to-LNG pathways consume similar amounts of fossil fuel. Because of relatively higher processing efficiency, CNG from NA NG uses somewhat less fossil fuel WTP than petroleum gasoline or LNG pathways.

Table 10 provides comparable results for LFG-to-LNG pathways. Again, pathways using on-site power generation and grid electricity are shown, as are pathways for LNG from NA NG and petroleum diesel, and PTW fossil fuel use is assigned a value of 1,000,000 for all fossil 
TABLE 10 WTW Fossil Fuel Use for LFG-to-LNG Pathways by Stage (Btu/MM Btu produced)

\begin{tabular}{|c|c|c|c|c|c|c|c|c|}
\hline \multirow{3}{*}{$\begin{array}{l}\text { Electricity Source } \\
\text { T\&D } \\
\end{array}$} & \multicolumn{6}{|c|}{ Landfill Gas-Based Liquefied Natural Gas } & \multirow{3}{*}{$\begin{array}{l}\text { LNG from } \\
\text { NA NG } \\
\\
\text { Off-Site: } \\
\text { Diesel } \\
\end{array}$} & \multirow[b]{3}{*}{ Diesel } \\
\hline & \multicolumn{3}{|c|}{ Distributed Generation } & \multicolumn{3}{|c|}{ U.S. Average Generation Mix } & & \\
\hline & On-Site & $\begin{array}{c}\text { Off-Site: } \\
\text { LNG }\end{array}$ & $\begin{array}{l}\text { Off-Site: } \\
\text { Diesel }\end{array}$ & On-Site & $\begin{array}{l}\text { Off-Site: } \\
\text { LNG }\end{array}$ & $\begin{array}{c}\text { Off-Site: } \\
\text { Diesel }\end{array}$ & & \\
\hline Feedstock Recovery & 0 & 0 & 0 & 0 & 0 & 0 & 31,559 & 41,332 \\
\hline Feedstock Transmission & 0 & 0 & 0 & 0 & 0 & 0 & 950 & 10,509 \\
\hline Fuel Production & 0 & 0 & 0 & 227,749 & 227,772 & 227,772 & 141,306 & 132,119 \\
\hline Fuel T\&D & 0 & 0 & 4,820 & 0 & 933 & 4,820 & 14,077 & 6,256 \\
\hline WTP & 0 & 0 & 4,820 & 227,749 & 228,705 & 232,592 & 187,892 & 190,215 \\
\hline Vehicle Operation & 0 & 0 & 0 & 0 & 0 & 0 & $1,000,000$ & $1,000,000$ \\
\hline WTW & 0 & 0 & 4,820 & 227,749 & 228,705 & 232,592 & $1,187,892$ & $1,190,215$ \\
\hline
\end{tabular}

pathways and zero for all renewable pathways. As shown in the table, if the electricity source for fuel production is grid electricity, LFG-to-LNG pathways consume more fossil fuel than LFG-toCNG pathways, largely because of differences in process efficiency. By contrast, if the LFG pathways use on-site distributed power and vehicles using the produced fuel are refueled off-site, the LFG-to-LNG pathways consume less fossil fuel than LFG-to-CNG pathways because CNG T\&D (grid electricity use for NG compression by electric compressor) is more energy-intensive than LNG T\&D (LFG-based LNG and diesel use for trucking). On a WTW basis, LFG-based LNG can consume $0-19 \%$ of the fossil fuel consumed by petroleum diesel.

\subsubsection{WTW Greenhouse Gas Emissions}

Figure 16 shows WTP, PTW, and WTW greenhouse gas emissions by pathway stage for LFG-based pathways, as compared with petroleum gasoline or CNG (from NA NG) pathways for light-duty vehicles and petroleum diesel or LNG (from NA NG) pathways for heavy-duty vehicles. Note that GHG emissions are expressed as grams carbon-dioxide equivalent $\left(\mathrm{g} \mathrm{CO}_{2} \mathrm{e}\right)$ per unit energy produced. Because of credits, LFG-based pathways generate far fewer GHG emissions than petroleum gasoline or diesel pathways.

As shown in Figure 16, WTW GHG emissions generally follow the same trend as WTW fossil fuel use (Figure 15). Gasoline- and diesel-fueled vehicles emit more GHGs than comparable CNG- or LNG-fueled vehicles. Thus, GHG emissions are substantially higher for petroleum-based pathways.

Tables 11 and 13 provide detailed results for GHG emissions by pathway stage in terms of grams per million Btu, while Tables 12 and 14 provide the results in terms of grams per MJ. Note that GHG results shown here are substantially different from the fossil fuel results shown in Tables 9 and 10. In the GHG calculations, GHGs are assumed to be captured and stored in the fuel during fuel production and released during vehicle operation. Thus, GHG emissions for vehicle operation (as shown in Table 11) tend to be considerably higher than the fossil fuel values shown in Table 9; the reverse is true for WTP fossil fuel use and GHG emissions. 


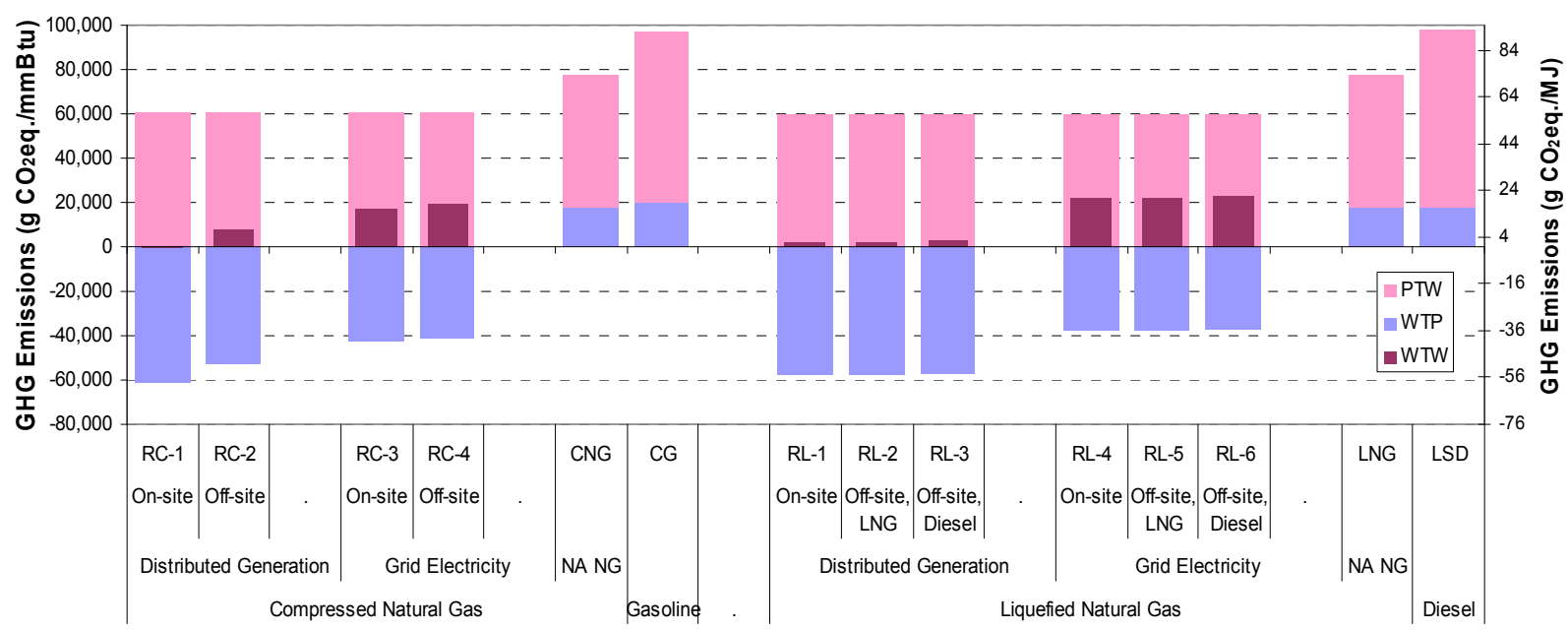

FIGURE 16 WTW GHG Emissions for LFG-Based Pathways Compared with NA NG and Petroleum Gasoline and Diesel Pathways

TABLE 11 WTW GHG Emissions for LFG-to-CNG by Pathway Stage (g $\mathrm{CO}_{2} \mathrm{e} / \mathrm{MM}$ Btu produced)

\begin{tabular}{|c|c|c|c|c|c|c|}
\hline \multirow{3}{*}{$\begin{array}{l}\text { Electricity Source } \\
\text { T\&D (Compression) }\end{array}$} & \multicolumn{4}{|c|}{ Landfill Gas-Based Compressed Natural Gas } & \multirow{3}{*}{$\begin{array}{c}\text { CNG from } \\
\text { NA NG } \\
\text { Off-Site }\end{array}$} & \multirow[b]{3}{*}{ Gasoline } \\
\hline & \multicolumn{2}{|c|}{ Distributed Generation } & \multicolumn{2}{|c|}{ U.S. Average Generation Mix } & & \\
\hline & On-Site & Off-Site & On-Site & Off-Site & & \\
\hline Feedstock Recovery & 0 & 0 & 0 & 0 & 3,758 & 3,153 \\
\hline Feedstock Transmission & 0 & 0 & 0 & 0 & 0 & 2,635 \\
\hline Fuel Production & $-64,988$ & $-59,119$ & $-47,328$ & $-47,551$ & 4,012 & 13,532 \\
\hline Fuel T\&D & 3,467 & 6,460 & 4,190 & 6,460 & 9,914 & 549 \\
\hline WTP & $-61,521$ & $-52,659$ & $-43,138$ & $-41,091$ & 17,684 & 19,869 \\
\hline Vehicle Operation & 60,484 & 60,484 & 60,484 & 60,484 & 60,484 & 77,594 \\
\hline WTW & $-1,036$ & 7,825 & 17,346 & 19,393 & 78,169 & 97,463 \\
\hline
\end{tabular}

TABLE 12 WTW GHG Emissions for LFG-to-CNG by Pathway Stage (g CO 2 e/MJ produced)

\begin{tabular}{|c|c|c|c|c|c|c|}
\hline \multirow{3}{*}{$\begin{array}{l}\text { Electricity Source } \\
\text { T\&D (Compression) }\end{array}$} & \multicolumn{4}{|c|}{ Landfill Gas-Based Compressed Natural Gas } & \multirow{3}{*}{$\begin{array}{c}\text { CNG from } \\
\text { NA NG } \\
\text { Off-Site }\end{array}$} & \multirow[b]{3}{*}{ Gasolin } \\
\hline & \multicolumn{2}{|c|}{ Distributed Generation } & \multicolumn{2}{|c|}{ U.S. Average Generation Mix } & & \\
\hline & On-Site & Off-Site & On-Site & Off-Site & & \\
\hline Feedstock Recovery & 0.0 & 0.0 & 0.0 & 0.0 & 3.6 & 3.0 \\
\hline Feedstock Transmission & 0.0 & 0.0 & 0.0 & 0.0 & 0.0 & 2.5 \\
\hline Fuel Production & -61.6 & -56.0 & -44.9 & -45.1 & 3.8 & 12.8 \\
\hline Fuel T\&D & 3.3 & 6.1 & 4.0 & 6.1 & 9.4 & 0.5 \\
\hline WTP & -58.3 & -49.9 & -40.9 & -38.9 & 16.8 & 18.8 \\
\hline Vehicle Operation & 57.3 & 57.3 & 57.3 & 57.3 & 57.3 & 73.5 \\
\hline WTW & -1.0 & 7.4 & 16.4 & 18.4 & 74.1 & 92.4 \\
\hline
\end{tabular}


TABLE 13 WTW GHG Emissions for LFG-to-LNG by Pathway Stage (g $\mathrm{CO}_{2} \mathrm{e} / \mathrm{MM}$ Btu produced)

\begin{tabular}{|c|c|c|c|c|c|c|c|c|}
\hline \multirow{3}{*}{ Electricity Source } & \multicolumn{6}{|c|}{ Landfill Gas-Based Liquefied Natural Gas } & \multirow{3}{*}{$\begin{array}{c}\text { LNG from } \\
\text { NA NG } \\
\\
\text { Off-Site: } \\
\text { Diesel } \\
\end{array}$} & \multirow[b]{3}{*}{ Diesel } \\
\hline & \multicolumn{3}{|c|}{ Distributed Generation } & \multicolumn{3}{|c|}{ U.S. Average Generation Mix } & & \\
\hline & On-Site & $\begin{array}{c}\text { Off-Site: } \\
\text { LNG }\end{array}$ & $\begin{array}{c}\text { Off-Site: } \\
\text { Diesel }\end{array}$ & On-Site & $\begin{array}{c}\text { Off-Site: } \\
\text { LNG }\end{array}$ & $\begin{array}{c}\text { Off-Site: } \\
\text { Diesel }\end{array}$ & & \\
\hline Feedstock Recovery & 0 & 0 & 0 & 0 & 0 & 0 & 3,790 & 4,706 \\
\hline Feedstock Transmission & 0 & 0 & 0 & 0 & 0 & 0 & 250 & 2,635 \\
\hline Fuel Production & $-57,831$ & $-61,155$ & $-61,155$ & $-37,810$ & $-41,132$ & $-41,133$ & 11,727 & 10,328 \\
\hline Fuel T\&D & 0 & 3,331 & 3,711 & 0 & 3,413 & 3,711 & 1,980 & 506 \\
\hline WTP & $-57,831$ & $-57,824$ & $-57,444$ & $-37,810$ & $-37,719$ & $-37,421$ & 17,748 & 18,175 \\
\hline Vehicle Operation & 60,198 & 60,198 & 60,198 & 60,198 & 60,198 & 60,198 & 60,198 & 79,719 \\
\hline WTW & 2,367 & 2,374 & 2,754 & 22,388 & 22,479 & 22,777 & 77,946 & 97,894 \\
\hline
\end{tabular}

TABLE 14 WTW GHG Emissions for LFG-to-LNG by Pathway Stage (g CO $2 \mathrm{e} / \mathrm{MJ}$ produced)

\begin{tabular}{|c|c|c|c|c|c|c|c|c|}
\hline \multirow{3}{*}{ Electricity Source } & \multicolumn{6}{|c|}{ Landfill Gas-Based Liquefied Natural Gas } & \multirow{3}{*}{$\begin{array}{c}\text { LNG from } \\
\text { NA NG } \\
\\
\text { Off-Site: } \\
\text { Diesel }\end{array}$} & \multirow[b]{3}{*}{ Diesel } \\
\hline & \multicolumn{3}{|c|}{ Distributed Generation } & \multicolumn{3}{|c|}{ U.S. Average Generation Mix } & & \\
\hline & On-Site & $\begin{array}{c}\text { Off-Site: } \\
\text { LNG }\end{array}$ & $\begin{array}{c}\text { Off-Site: } \\
\text { Diesel }\end{array}$ & On-Site & $\begin{array}{c}\text { Off-Site: } \\
\text { LNG }\end{array}$ & $\begin{array}{c}\text { Off-Site: } \\
\text { Diesel }\end{array}$ & & \\
\hline Feedstock Recovery & 0.0 & 0.0 & 0.0 & 0.0 & 0.0 & 0.0 & 3.6 & 4.5 \\
\hline Feedstock Transmission & 0.0 & 0.0 & 0.0 & 0.0 & 0.0 & 0.0 & 0.2 & 2.5 \\
\hline Fuel Production & -54.8 & -58.0 & -58.0 & -35.8 & -39.0 & -39.0 & 11.1 & 9.8 \\
\hline Fuel T\&D & 0.0 & 3.2 & 3.5 & 0.0 & 3.2 & 3.5 & 1.9 & 0.5 \\
\hline WTP & -54.8 & -54.8 & -54.4 & -35.8 & -35.8 & -35.5 & 16.8 & 17.2 \\
\hline Vehicle Operation & 57.1 & 57.1 & 57.1 & 57.1 & 57.1 & 57.1 & 57.1 & 75.6 \\
\hline WTW & 2.2 & 2.2 & 2.6 & 21.2 & 21.3 & 21.6 & 73.9 & 92.8 \\
\hline
\end{tabular}

\subsection{ENERGY AND GREENHOUSE GAS EMISSIONS PER MILE TRAVELED}

\subsubsection{LFG-Based CNG}

As shown in Figure 17, total energy use across all LFG-to-CNG pathways and for the petroleum gasoline pathway is nearly flat. Total energy use is slightly higher for petroleum gasoline and slightly lower for LFG-to-CNG pathways with grid electricity. Because of lower process energy use, the NA NG-based CNG pathway consumes approximately 5-8\% less energy per mile traveled than other pathways.

However, this relative advantage disappears when compared on the basis of either fossil fuel use or GHG emissions per mile traveled (Figures 18 and 19). Although approximately 6\% better than petroleum gasoline, CNG from NA NG consumes more fossil fuel and emits more GHGs than LFG-based CNG. Because vehicle operation uses renewable, LFG-based fuel, GREET results show a reduction in WTW fossil fuel use and GHGs of 76-100\% for LFG-based pathways, as compared with fossil NA NG. 


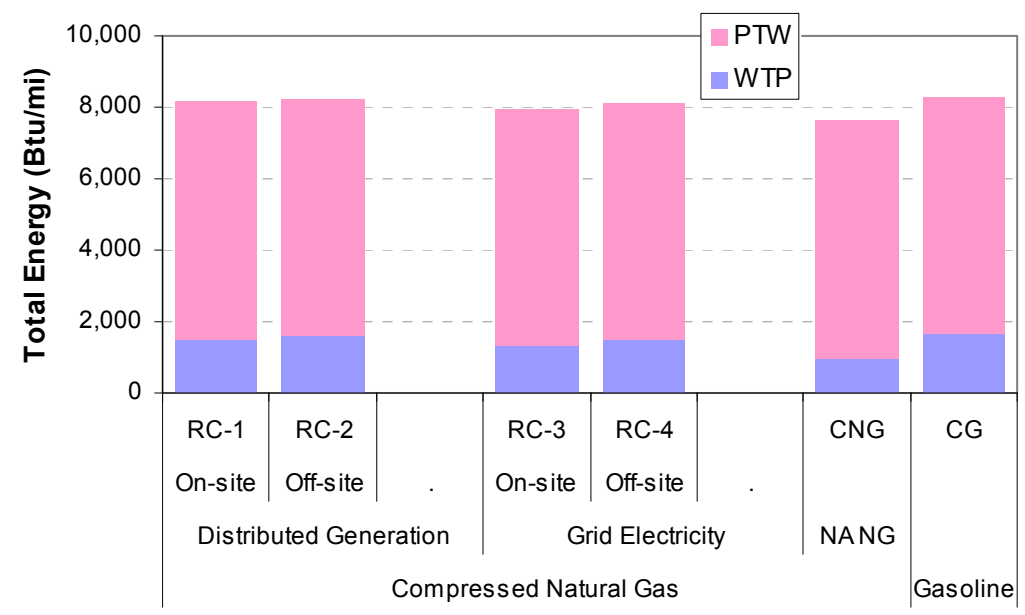

FIGURE 17 Energy Use for CNG from LFG or Fossil NA NG, versus Petroleum Gasoline (Btu/mi)

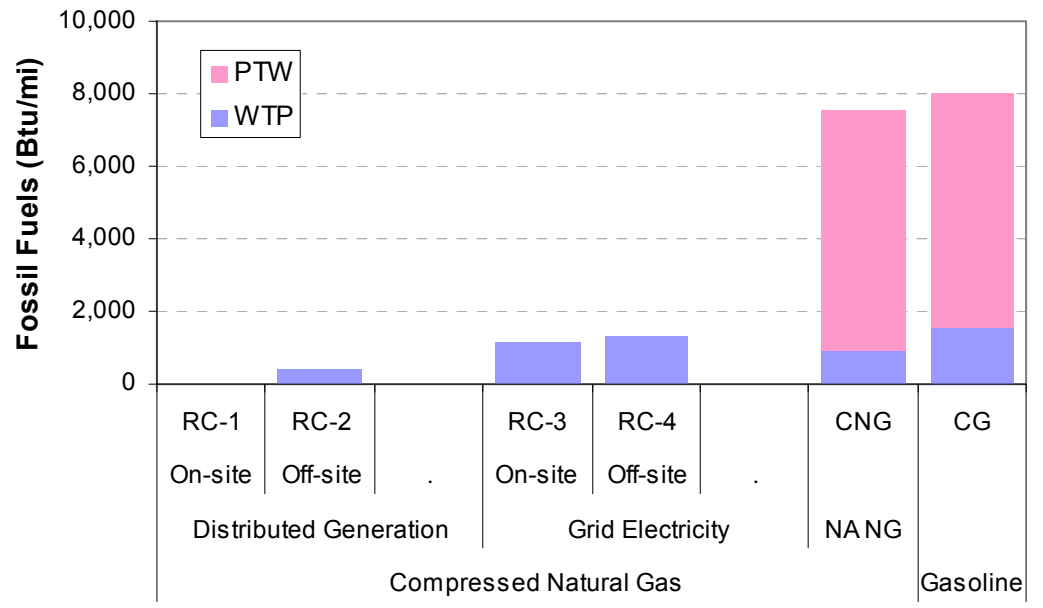

FIGURE 18 Fossil Fuel Use for CNG from LFG or Fossil NA NG, versus Petroleum Gasoline (Btu/mi) 


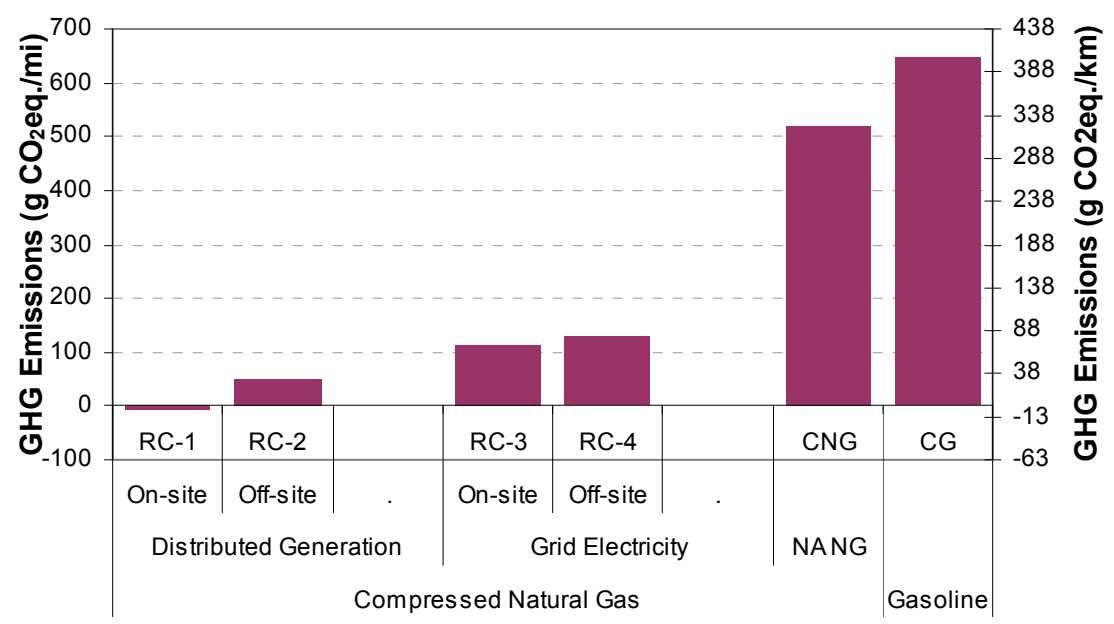

FIGURE 19 GHG Emissions for CNG from LFG or Fossil NA NG, versus Petroleum Gasoline ( $\mathrm{g} \mathrm{CO}_{2} \mathrm{e} / \mathrm{mi}$ or $\mathrm{km}$ )

\subsubsection{LFG-Based LNG}

With the exception of petroleum diesel, energy-use-per-mile-traveled is relatively flat for the pathways examined. As shown in Figure 20, total energy use is slightly higher for LFG-toLNG pathways as compared with LNG from fossil NA NG. Because of lower process energy use and more fuel efficient vehicle operation, the petroleum diesel pathway consumes approximately $10-17 \%$ less energy per mile traveled than other pathways.

However, this relative advantage disappears when compared on the basis of either fossil fuel use or GHG emissions per mile traveled (Figures 21 and 22). Although still approximately $10 \%$ better than LNG from fossil NA NG, diesel consumes far more fossil fuel than LFG-based pathways. Because vehicle operation uses renewable LNG, GREET results show a significant reduction in WTW fossil fuel use and GHGs for all LFG-based pathways. Although LNG from fossil NA NG emits approximately $12 \%$ less GHGs than the petroleum diesel pathway (primarily due to cleaner vehicle operation), LFG-based pathways reduce GHGs by $72-97 \%$. 


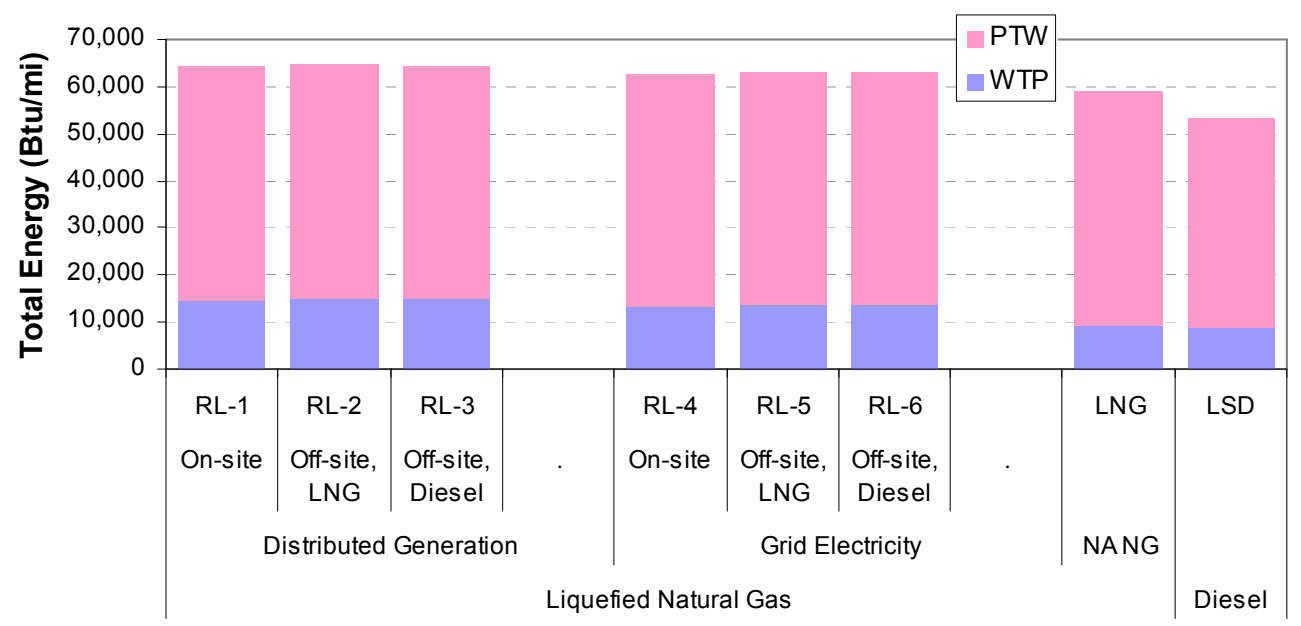

FIGURE 20 Energy Use for LNG from LFG or Fossil NA NG, versus Petroleum Diesel (Btu/mi)

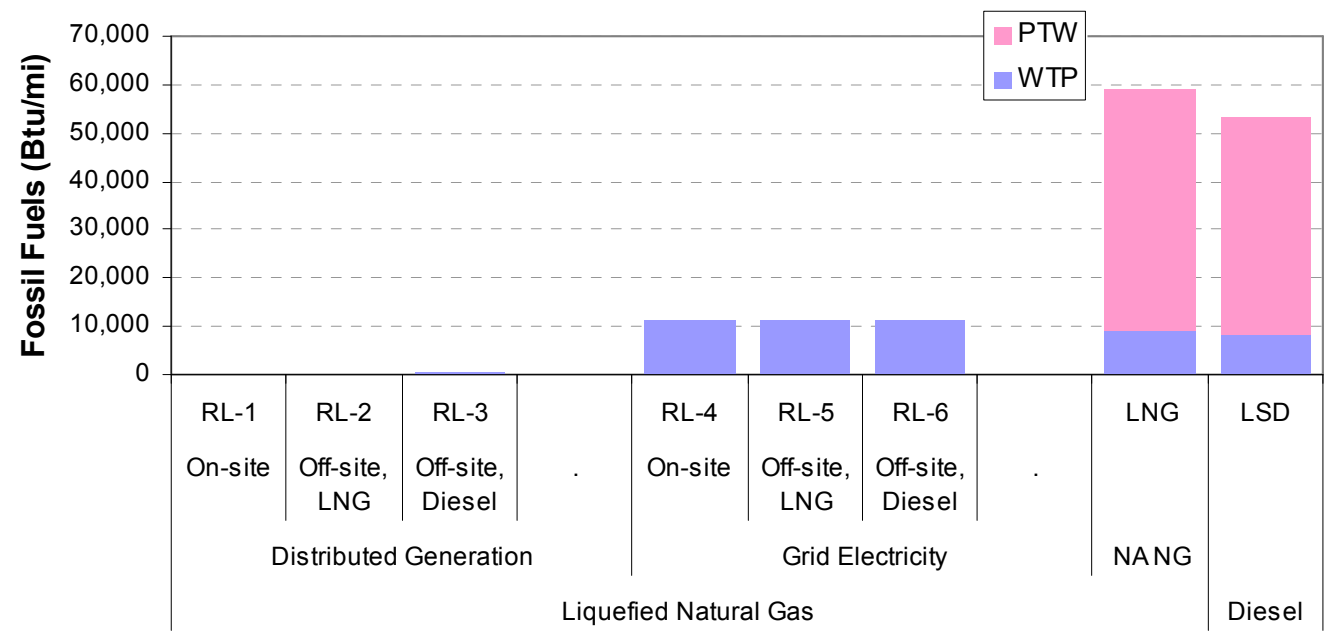

FIGURE 21 Fossil Fuel Use for LNG from LFG or Fossil NA NG, versus Petroleum Diesel (Btu/mi) 


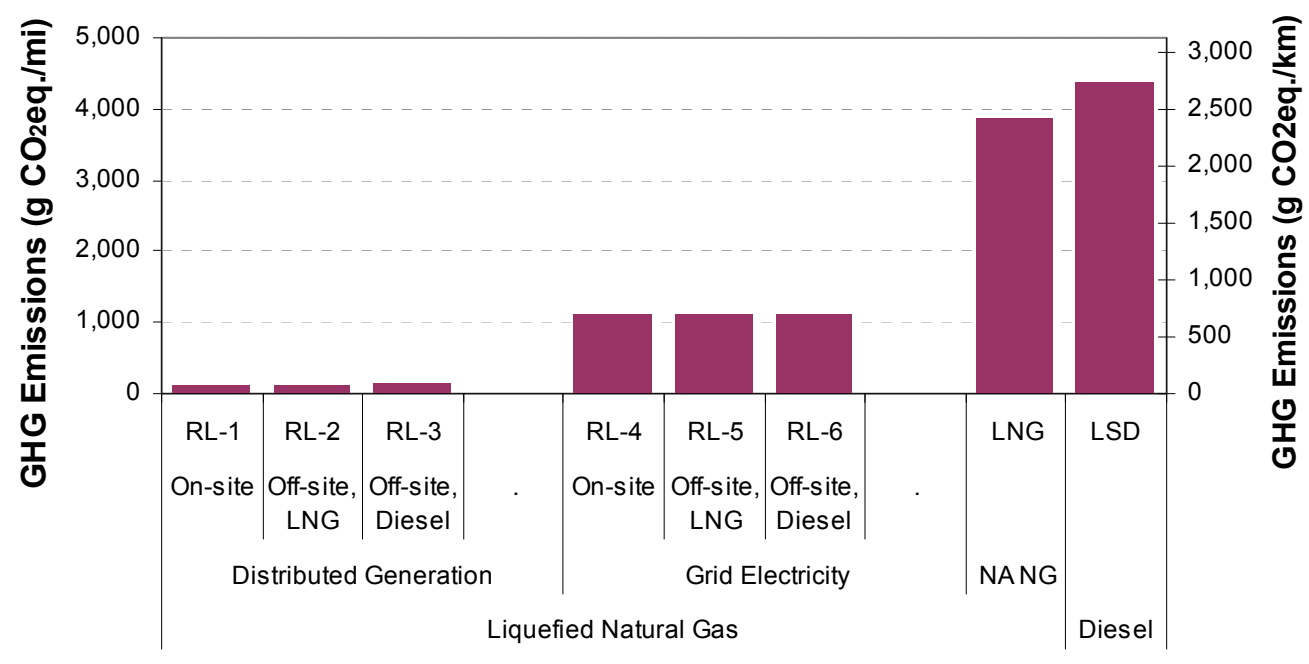

FIGURE 22 GHG Emissions for LNG from LFG or Fossil NA NG, versus Petroleum Diesel (g CO $2 \mathrm{e} / \mathrm{mi}$ or $\mathrm{km})$

\subsection{BALANCING ENERGY EFFICIENCY WITH GREENHOUSE GAS EMISSIONS}

Grid electricity is almost always more energy efficient than LFG-fueled generators since the former's fuel source is more energy dense and power plants can achieve better process integration and on-line operation at larger scale. Thus, LFG-based pathways are often less energy efficient than petroleum and NA NG-based pathways. However, because LFG-based CNG and LNG are renewable fuels, total energy use is not a relevant metric for comparison with fossil fuels. By definition, renewable energy is not "consumed." Within the timeframe of lifecycle analysis (e.g., 100 years), the supply of renewable energy is infinite and there is no detriment to tapping larger quantities. Thus, renewable energy "use" is irrelevant and a renewable pathway is preferable to a non-renewable one on the basis of total energy use. ${ }^{13}$

On the other hand, we can compare the fossil fuel use and emissions of renewable and non-renewable fuel pathways because the relevant systems can be well defined and the units of analysis can be properly measured. As a result, although comparisons of total energy, fossil energy, and greenhouse gas emissions are presented above, the reader is urged to focus on fossil energy and greenhouse gas emissions. Those are the key comparisons between two fundamentally different types of fuel pathways.

\footnotetext{
${ }^{13}$ Among renewable pathways, however, it can be argued that lower energy pathways are preferable (all other things equal) since more work can be produced for a given quantity of energy, thereby increasing the benefit to society (e.g., by increasing displacement of imported oil).
} 


\subsection{CO-PRODUCT AND RENEWABLE ENERGY CREDITS}

In addition to generating excess power to the grid (i.e., co-product electricity), LFGbased pathways may produce elemental sulfur, ash, and carbon dioxide $\left(\mathrm{CO}_{2}\right)$, as well as renewable energy credits. ${ }^{14}$ Since ash would have been produced from the flare in the reference case (see Figure 6), it is not considered a by-product of LFG-based pathways. Similarly, capturing sulfur upstream (instead of at the flare) is not a net change. Thus, $\mathrm{CO}_{2}$ is the major potential co-product. Although not a co-product per se, renewable energy credits are an important side benefit since they can provide significant financial incentives to LFG fuel projects.

\subsubsection{Carbon Dioxide}

Each year, some 50 million short tons of $\mathrm{CO}_{2}$ for chemical or mechanical use are produced from U.S. wells. Production from industrial processes accounts for another 15 million tons. The vast majority (35 million short tons) is used for enhanced oil recovery (EOR), mostly via pipeline from large supplies. While by-product $\mathrm{CO}_{2}$ produced from LFG conversion to natural gas could serve nearby EOR needs or supplement pipeline supplies, geography and scale are likely to limit its market potential.

Similarly, $\mathrm{CO}_{2}$ produced from LFG is unlikely to penetrate the beer or carbonated soft drink market since ample quantities of "food-grade" $\mathrm{CO}_{2}$ are available from natural or other sources, including ethanol processing. So, despite the ability of some LFG-to-NG processors to certify their $\mathrm{CO}_{2}$ co-product to food-grade standards, the beverage market is unlikely to become a major customer.

On the other hand, dry ice (solid $\mathrm{CO}_{2}$ ), urea manufacture, and pest control are promising options for LFG-based $\mathrm{CO}_{2}$ co-product. Dry ice has long been the refrigerant of choice for packaging and small-lot transport of perishables that must remain frozen until use. However, since dry ice requires further processing, a secondary deposition process would be needed at LFG sites to transform $\mathrm{CO}_{2}$ into blocks and sheets suitable for packaging. A more promising market is in chemical manufacturing where $\mathrm{CO}_{2}$ has long played multiple roles as raw material, reactant, pressurizing agent, and coolant. Production of various carbonates, polycarbonate resins, and urea rely on $\mathrm{CO}_{2}$ as a feedstock. The urea market is estimated to demand nearly 4 million tons/yr of $\mathrm{CO}_{2}$, which should expand if selective catalytic reduction of $\mathrm{NO}_{\mathrm{x}}$ in diesel engine exhaust becomes the emission control technology of choice for heavy-duty trucks.

Outside California, pest fumigation (especially in large-scale grain storage) may be a good logistical match for co-product $\mathrm{CO}_{2}$. Historically, ethyl di-bromide (EDB) and methyl bromide (MB) were the main fumigants used in grain storage. However, EPA banned EDB in 1984 (as a suspected carcinogen) and ordered a phaseout of MB in 2005 (as an ozone-depleting chemical). $\mathrm{CO}_{2}$ and nitrogen are potential alternatives to $\mathrm{MB}$. The main advantage of $\mathrm{CO}_{2}$ is that it is toxic to insects and can tolerate up to $3 \%$ oxygen in controlled atmospheres, which nitrogen cannot. A disadvantage is the porosity of most storage facilities, which can lose their $\mathrm{CO}_{2}$-rich

\footnotetext{
${ }^{14}$ Since all NG produced from LFG is assumed to be used as a vehicle fuel (with either on-site or off-site fueling), GREET pathways have no NG co-product.
} 
fumigation atmospheres before the approximately nine days required for full effectiveness. If this latter problem can be resolved, $\mathrm{CO}_{2}$ application to elevator storage of spring and winter wheat could represent a market for up to $20,000 \mathrm{t} / \mathrm{yr}$ of $\mathrm{CO}_{2}$.

Additional uses for $\mathrm{CO}_{2}$ (e.g., as a foam blowing agent in polyurethane and polystyrene production, an aerosol propellant, a cleaning agent at paper pulp mills, or as a natural plant nutrient in greenhouses) hold limited promise, generally circumscribed by geographic proximities and other competing compounds. Because of the above-noted uncertainties and the likelihood that market success will be very site-specific, co-product $\mathrm{CO}_{2}$ is not represented in the LFG-based pathways developed for this study.

\subsubsection{Renewable Energy Credits and Other Incentives}

Thirty-five states currently require electric utilities to generate a minimum share of the power sold within their borders from renewable or alternative energy sources by a given date (Pew 2009). Called "Renewable Portfolio Standards" (RPSs), most of these mandates specifically include landfill gas as an eligible energy source (Pew 2009, EPA 2009a). Although RPSs focus on replacing fossil with renewable fuels for power generation, the concept is likely to be expanded to natural gas in the form of low carbon fuel standards (like those already adopted in California) or greenhouse gas allowances (like those being considered under various carbon cap and trade proposals). Already, a few states (e.g., Montana, Michigan, and Kansas) frame their RPSs in terms of energy (as opposed to electricity) consumption. LFG pathways to vehiclefuel or pipeline-quality gas may qualify under these latter standards.

Several states have adopted or are considering the adoption of regulations permitting utilities to buy, sell, or trade Renewable Energy Certificates (RECs) in order to comply with RPSs or other mandates. RECs are tradable commodities that represent proof that a given amount of electricity was generated from an eligible renewable energy resource. In states with a REC program, "green" energy providers (such as producers of LFG-based electricity that is exported to the grid or of pipeline quality gas that is used to generate renewable electricity) are credited with one REC for every $1,000 \mathrm{kWh}$ (1 MWh) of electricity produced. A certifying agency gives each REC a unique identification number to make sure it does not get double-counted. The green energy is fed into the electric grid, and the accompanying REC can be sold, traded, or bartered on the open market. The owner of the REC can then claim to have purchased renewable energy, even though the energy associated with the REC is sold separately and used by another party (EPA 2009a).

Various federal incentives are available to support LFG projects. These include tax credits and funding sources, like the Renewable Electricity Production Tax Credit; the Business Energy Investment Tax Credit; and Clean Renewable Energy Bonds (authorized under Sections 45, 48, and 54, respectively, of the U.S. Tax Code), Qualified Energy Conservation Bonds, and the Renewable Energy Production Incentive (created in 1992 and reauthorized to extend through 2026). Other incentives include Renewable Energy Grants, Energy Efficiency and Conservation Block Grants, and Innovative Technology loan guarantees. Historically, most of these incentives have been limited to generating power from LFG and exporting it to the grid. Now, however, a number of them have been expanded to cover facilities "functionally related and subordinate to the generation facility itself" (which could include gas cleanup, compression, and pipeline injection), and funding has been supplemented with appropriations from the American Recovery and Reinvestment Act (ARRA). 
The waste-to-energy industry is poised for growth as new markets for their "green power" emerge and new funding sources provide the wherewithal to accelerate LFG-based fuel development. According to David Wentworth, president of Renewable Solutions Group, "Landfill gas to electricity projects have flourished over the past several decades, primarily as a means to capture federal tax benefits, but they produce limited environmental benefits when compared to high Btu applications...The next evolution is landfill gas to pipeline-quality gas projects, which can be used to heat homes, power natural gas vehicles and illuminate city streets, all while providing financial and environmental benefits" (Pomerantz 2009).

\subsection{CRITERIA POLLUTANT EMISSIONS}

Detailed well-to-wheel estimates of criteria pollutant emissions are provided in Appendix B. For criteria pollutants like carbon monoxide (CO), emissions are dominated by vehicle operation since relatively little of the pollutant is emitted from fuel production. For others (e.g., $\mathrm{NO}_{\mathrm{x}}, \mathrm{PM}$ and $\mathrm{SO}_{\mathrm{x}}$ ), emissions are pathway dependent. $\mathrm{NO}_{\mathrm{x}}$ and $\mathrm{PM}$ emissions vary with grid electricity use because the emission factors of the U.S. average power mix (see Table 4) are much higher than those of on-site power generators, which, in turn, are higher than those of LFG flares. WTW $\mathrm{SO}_{\mathrm{x}}$ emissions are virtually eliminated if no grid electricity is used in the pathway because all sulfur emissions are balanced with the credit from the avoided LFG flaring. 


\section{CONCLUSIONS}

This study characterized landfill gas (LFG) resources and the technologies to convert what until recently was considered a waste product into a renewable fuel for vehicles. By using this information, several LFG-based pathways were added to the GREET model. Results show:

- As compared with North American natural gas (NA NG) or petroleum-based fuel, LFGbased fuels require roughly the same quantity of energy for their production, transport, and utilization in vehicles. However, with LFG-based fuels, much of this energy is considered renewable since it is from organic sources and is replenished naturally.

- LFG-based fuels can save significant amounts of fossil fuel. The size of such savings, however, depends on the amount of electricity used in the pathway.

- LFG-based fuels can dramatically reduce greenhouse gas (GHG) emissions, particularly if process energy is supplied by on-site power generators using renewable LFG. If process energy is supplied by grid electricity, reductions in GHG emissions depend on the U.S. power generation mix.

- WTW criteria pollutant emissions depend on both the amount of electricity used and differences in emission factors between relevant pathway components and the base or reference case (e.g., $\mathrm{CNG} / \mathrm{LNG}$ versus gasoline/diesel vehicles, LFG flares versus IC engines, LFG gensets versus the average U.S. power generation mix).

Because of limited time and resources, this study could not address several issues and concerns. Chief among them are emissions of toxics and hazardous substances from landfills. These substances are present in the current waste stream, and we assume that they are successfully captured and destroyed in the thermal oxidizer (flare). However, some argue that LFG capture rates are less than assumed, destruction of NMOC and other pollutants is incomplete (contributing to additional emissions), and that some hazardous materials are not adequately sequestered within the landfill. These issues are extremely important and merit a detailed examination. That examination is beyond the scope of this analysis.

This analysis also assumes that conventional waste management strategies will continue to be used and to produce landfill gas comprising some $45-50 \%$ methane and $35-40 \% \mathrm{CO}_{2}$ (see Table 2). As noted above, LFG capture is uncertain and may change with new technologies, like bioreactors or source-separation coupled with anaerobic digestion of organic materials. These technologies are extremely promising since they speed waste stabilization and, therefore, the economic recovery of product gas. Beyond this, however, they may also increase LFG capture rates and methane concentrations in the LFG feed. Although extremely important and significant, these issues lie outside the system boundary and thus could not be addressed in this analysis.

Finally, while this study assumes a robust market for LFG-based fuel, market issues are beyond the scope of this analysis. Because there are many renewable sources for electricity but few for natural gas, renewable natural gas may be an increasingly attractive option for entities 
required to implement low carbon fuel standards and renewable portfolio standards. However, recent historically low spark spreads between natural gas and electricity prices have given way to low natural gas prices and high spark spreads. As a result, projects to produce pipeline quality natural gas are less viable in today's economic climate than they were a couple of years ago. However, the price differential between natural gas for stationary applications versus competing motor fuels remains significant. 


\section{REFERENCES}

Acrion Technologies, Inc., 2009, Acrion's $\mathrm{CO}_{2}$ Wash Process for Contaminants Removal from Landfill Gas, accessed Aug. 2009 at http://www.acrion.com/CO2wash.htm.

Air Liquide, 2009, Biogas Recovery System, accessed Sept. 2009 at http://www.dta.airliquide.com/file/otherelement/pj/plaquette-biogaz57164.pdf.

ARCADIS Geraghty \& Miller, Inc., 2002, "Update Heavy-Duty Engine Emission Conversion Factors for MOBILE6, Analysis of BSFCs and Calculation of Heavy-Duty Engine Emission Conversion Factors," EPA420-R-02-005, January 2002.

Barnitt, R., and K. Chandler, 2006, New York City Transit Hybrid and CNG Transit Buses: Interim Evaluation Results, National Renewable Energy Laboratory Report NREL/TP-540-38843, November.

Brendeng, E., and J. Hetland, 2004, "State of the Art in Liquefaction Technologies for Natural Gas, NATO Science Series, Series II: Mathematics, Physics and Chemistry, edited by J. Hetland and T. Gochitashvili, Vol. 149.

Brinkman, N., M. Wang, T. Weber, and T. Darlington, 2005, Well-to-Wheels Analysis of Advanced Fuel/Vehicle Systems - A North American Study of Energy Use, Greenhouse Gas Emissions, and Criteria Pollutant Emissions, Argonne National Laboratory, Argonne, IL.

California Air Resources Board (CARB), 2009, ARB Adopts Landfill Measure to Reduce Potent Global Warming Gas, News Release, California Environmental Protection Agency, June 25.

Chandler, K., P. Norton, and N. Clark, 2001, Waste Management's LNG Truck Fleet: Final Results, National Renewable Energy Laboratory Report NREL/BR-540-29073, January.

Chandler, K., P. Norton, and N. Clark, 2000, Dallas Area Rapid Transit's (DART) LNG Bus Fleet: Final Results, National Renewable Energy Laboratory Report NREL/BR-540-28739, November.

Chandler, K., E. Eberts, and M. Melendez, 2006, Washington Metropolitan Area Transit Authority: Compressed Natural Gas Transit Bus Evaluation, National Renewable Energy Laboratory Report NREL/TP-540-37626, April.

Cook, W., W. Brown, L. Siwajek, W. Sanders, and I. Botgros, 1998, Greenhouse Gas Reduction by Recovery and Utilization of Landfill Methane and $\mathrm{CO}_{2}$ : Technical and Market Feasibility Study, Boului Landfill, Bucharest, Romania, U.S. DOE Assistant Secretary for Energy Efficiency and Renewable Energy Report DOE/EE/35034-T1, Washington, D.C.

Cook, W., M. Neyman, L. Siwajek, and W. Brown, 2002, Landfill Gas to LNG and LCO2, 2001 Annual Report, Brookhaven National Laboratory, Upton, NY. 
Cook, W., W. Brown, L. Siwajek, M. Neyman, T. Reppert, and B. Smackey, 2005, Production of Liquid Methane Truck Fuel from Landfill Gas, Final Report, Brookhaven National Laboratory, Upton, NY.

Cummins-Westport Inc. (CWI), 2009, ISL G (North America), accessed Sept. 2009 at http://www.cumminswestport.com/products/islg.php.

Datta, A.K., and P.K. Sen, 2006, "Optimization of Membrane Unit for Removing Carbon Dioxide from Natural Gas,” Journal of Membrane Science, 283(1-2):291-300.

Dunn, S., 2000, "Micropower: The Next Electrical Era," Worldwatch Paper 151, Worldwatch Institute, Washington, D.C.

Electric Power Research Institute (EPRI), 2004, Distributed Energy Resources Emissions Survey and Technology Characterization, Electricity Innovation Institute, Palo Alto, CA.

Energy Information Administration (EIA), 2008, U.S. Crude Oil, Natural Gas and Natural Gas Liquids Reserves, 2007 Annual Report, accessed Aug. 2009 at http://www.eia.doe.gov/pub/oil gas/natural gas/data publications/crude oil natural gas reserv es/historical/2007/cr2007.html.

EIA, 2009a, Annual Energy Review 2008, Report No. DOE/EIA-0384(2008), accessed Aug. 2009 at http://www.eia.doe.gov/emeu/aer/contents.html.

EIA, 2009b, Natural Gas Year-In-Review 2008, accessed Aug. 2009 at http://www.eia.doe.gov/pub/oil_gas/natural_gas/feature_articles/2009/ngyir2008/ngyir2008.html.

Finn, A.J., G.L. Johnson, and T.R. Tomlinson, 1999, "Developments in Natural Gas Liquefaction," in Hydrocarbon Processing, pp. 47-59.

Franklin Associates, a Division of ERG, Review of State Solid Waste Management Websites, cited in U.S. EPA, 2008, Municipal Solid Waste in the United States: Facts and Figures for 2007, EPA-530-R-08-010, Office of Solid Waste, Washington, D.C.

Gas Technology Institute (GTI), 2007, Liquefied Natural Gas from Landfill Gas Demonstration Grant, California Integrated Waste Management Board.

Goldstein, L., B. Hedman, D. Knowles, S. Freedman, R. Woods, and T. Schweizer, 2003, GasFired Distributed Energy Resource Technology Characterizations, National Renewable Energy Laboratory Report NREL/TP-620-34783, Golden, CO.

Godlove, C., 2010, Landfill Gas Successes and Challenges in an Increasingly Complex Market, SWANA's 33 ${ }^{\text {rd }}$ Annual Landfill Gas Symposium, San Diego, March 10.

Johansson, N., 2008, Production of Liquid Biogas, LBG, with Cryogenic and Conventional Upgrading Technology - Description of Systems and Evaluations of Energy Balances, M.S. Thesis, Lunds University, Sweden. 
Kikkawa, Y., and I. Aoki, 1999, Gas to Liquid of 21st Century, AIChE Spring National Meeting, Houston, p. 48, March 14-18.

Kikkawa, Y., and N. Nozawa, 1999, Optimizing Liquefied Natural Gas Power Chain, AIChE Spring National Meeting, Houston, March 14-18.

Kikkawa, Y., and Y.N. Liu, 2001, Zero $\mathrm{CO}_{2}$ Emission for LNG Power Chain?, $13^{\text {th }}$ International Conference and Exhibition on Liquefied Natural Gas, PS5-3.

Kohl, A., and R. Nielsen, 1997, Gas Purification, $5^{\text {th }}$ ed., Gulf Publishing, Houston.

Lear, J. and J. Burdelski, 2009. U.S. Department of Energy/Brookhaven National Laboratory, Biomethane Analysis, Draft Report.

Ludwig, V., 2009. Landfill Gas to Energy Webcast (transcript and slides), USEPA, Feb. 18, accessed Aug. 2009 at http://www.epa.gov/cleanenergy/energy-programs/state-andlocal/webcast.html\#feb5.

Persson, M., O. Jönsson, and A. Wellinger, 2006, Biogas Upgrading to Vehicle Fuel Standards and Grid Injection, IEA Bioenergy, Task 37 - Energy from Biogas and Landfill Gas, accessed June 28, 2010, at http://www.iea-biogas.net/Dokumente/upgrading report final.pdf.

Pew Center on Global Climate Change, 2009, Renewable and Alternative Energy Portfolio Standards, July 29, accessed Aug. 2009 at http://www.pewclimate.org/what s being_done/ in the states/rps.cfm.

Pickens, T.B., Pickens Plan, undated, accessed Sept. 2009 at http:/www.pickensplan.com/theplan/.

Pomerantz, M., 2009, "Tapping the Trash," Waste Age, April 1, accessed Aug. 2009 at http://wasteage.com/Landfill_Management/landfill-methane-pipeline-quality-gas-200904/.

Pomerantz, M., and L. Turcotte, 2004, Production of Pipeline Gas from Landfill Gas in Canada, Wastecon 2004, Sept. 21-23, Phoenix.

Prometheus Energy Company, 2007, Liquefied Natural Gas from Landfill Gas Demonstration Grant, California Integrated Waste Management Board.

Remeljej, C.W., and A.F. Hoadley, 2006, “An Exergy Analysis of Small-Scale Liquefied Natural Gas (LNG) Liquefaction Processes,” Energy, 31:2005-2019.

SCS Engineers, 2007. Current MSW Industry Position and State of the Practice on Methane Destruction Efficiency in Flares, Turbines, and Engines, prepared for Solid Waste Industry for Climate Solutions, July.

Segeler, C.G., 1965, Gas Engineers Handbook, Industrial Press. 
Sperling Hansen Associates, 2007, Highland Valley Centre for Sustainable Waste ManagementLandfill Gas Utilization Options, SHA-PRJ06014, accessed July 2009 at http://a100.gov.bc.ca/appsdata/epic/html/deploy/epic project doc index_263.html.

Spillman, R., 1995. "Economics of Gas Separation Membrane Process," in Membrane Separations Technology: Principles and Applications $3^{\text {rd }}$ Edition (edited by R.D. Noble, S.A. Stern), Elsevier Science.

Sullivan, P., 2010, The Importance of Landfill Gas Capture and Utilization in the U.S., Council for Sustainable Use of Resources and Earth Engineering Center, Columbia University, April, accessed May 2010 at http:/www.scsengineers.com/Papers/Sullivan_Importance of_LFG_Capture and_Utilization_in the US.pdf.

Syed, M., G. Soreanu, P. Falletta, and M. Beland, 2006, "Removal of Hydrogen Sulfide from Gas Streams Using Biological Processes: A Review," Canadian Biosystems Engineering, 48:2.1-2.14.

TRC Environmental Corp., 2008, Emissions Testing of the Ward Hill Neck Landfill Enclosed Landfill Gas Flare and Landfill Gas Engine, prepared for Covanta Haverhill, Inc., Windsor, CT, TRC project no. 158673-0000-00000, July 21.

U.S. Environmental Protection Agency (EPA), 1995, Compilation of Air Pollutant Emission Factors, Vol. 1: Stationary Point and Area Sources, AP-42, $5^{\text {th }}$ Edition, Research Triangle Park, NC.

U.S. EPA, 2008, Municipal Solid Waste in the United States: Facts and Figures for 2007, EPA530-R-08-010, Office of Solid Waste, Washington, D.C.

U.S. EPA, 2010a, Energy Projects and Candidate Landfills as of April 2010, accessed May 2010 at http://www.epa.gov/lmop/projects-candidates/index.html\#map-area.

U.S. EPA, 2010b, Engine Certification Data, accessed May 2010 at http://www.epa.gov/oms/certdata.htm\#largeng

U.S. EPA, 2009a, Renewable Portfolio Standards: An Effective Policy to Support Clean Energy Supply April, accessed Aug. 2009 at http://www.epa.gov/chp/state-policy/renewable fs.html.

U.S. EPA, Office of Air Quality, 2000, Economic Impact Analysis: Municipal Solid Waste Landfills, EPA-452/D-00-005, Sept., accessed Sept. 2009 at http://yosemite.epa.gov/ee/epa/ria.nsf/vwAN/A2000-37.pdf/\$file/A2000-37.pdf.

U.S. EPA, Natl. Center for Environmental Economics, 1996, Landfill Rules Tightened, from I. Fisher, "EPA Rules Require Curbs on Landfills' Gas Emissions," New York Times, March 3, accessed Sept. 2009 at http://yosemite.epa.gov/ee/epalib/nwlet.nsf/ 434d5673ac53b154852564cd007a8a0d/6422179d25e7e87e852564d800092f41! OpenDocument. 
University of Florida and University of Central Florida, 2008, Florida Bioreactor Landfill Demonstration Project, Executive Summary, July 1, accessed Aug. 2009 at http://www.bioreactor.org.

Vink, K.J., and R.K. Nagelvoort, 1998, Comparison of Baseload Liquefaction Processes, in Proc. $12^{\text {th }}$ Intl. Conference and Exhibition on Liquefied Natural Gas, Perth, Australia, p. 3.6, May 4-7.

Wang, M., D. He, A. Finizza, T. Weber, M. Miller, D. Masten, G. Skellenger, and J.P. Wallace, 2001, Well-to-Wheel Energy Use and Greenhouse Gas Emissions of Advanced Fuel/Vehicle Systems - North American Analysis, General Motors Corporation, Argonne National Laboratory, BP, ExxonMobil, Shell, accessed July 2009 at http://www.transportation.anl.gov/ pdfs/TA/163.pdf.

Watt, G.M., 2000, Natural Gas Vehicle Transit Bus Fleets: The Current International Experience, $7^{\text {th }}$ Intl. Conference and Exhibition on Natural Gas Vehicles (NGV 2000), Oct. 17-19, Yokohama, Japan. 


\section{APPENDIX A: SMALL-SCALE NATURAL GAS LIQUEFACTION}

Liquefied natural gas (LNG) is produced by cooling natural gas (NG) to its boiling point $\left(-260^{\circ} \mathrm{F}\right)$ at atmospheric pressure. A number of different processes (or cycles) can be used, the chief types being cascade, mixed refrigerant, and expander. Schematics of the processes are presented in Figure A-1.

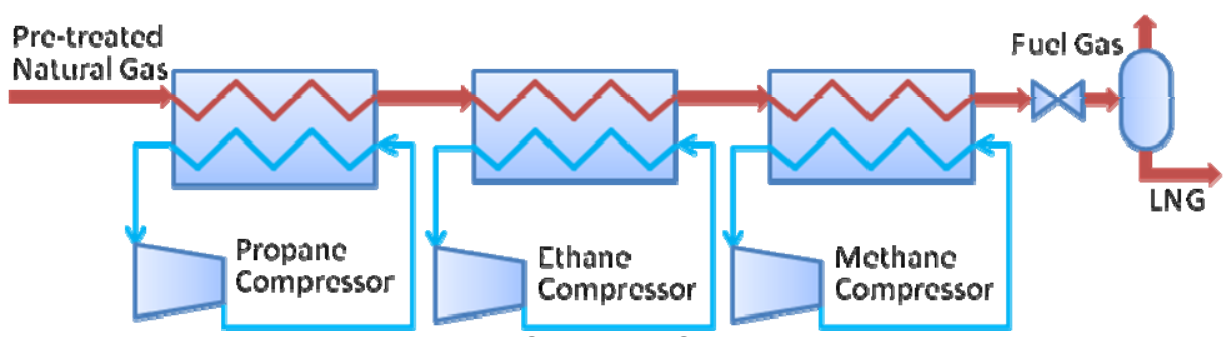

(a) Cascade Cycle

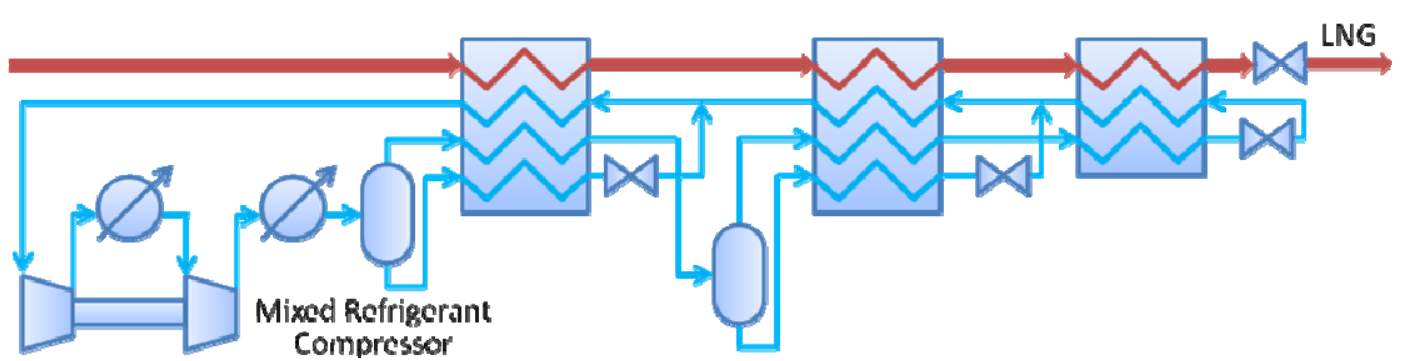

(b) Mixed Refrigerant Cycle

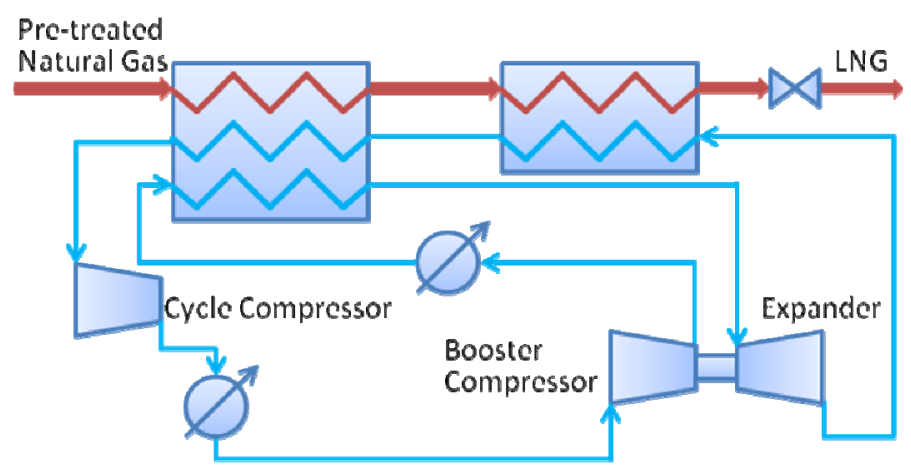

(c) Expander Cycle

FIGURE A-1 Schematics of NG Liquefaction Processes

The cascade cycle generally uses a different pure refrigerant (propane, ethane [or ethylene], or methane) for each of its three stages. The major advantage of the cycle is its high efficiency and simplicity of design; disadvantages include relatively high capital cost due to the number of refrigerant compression cycles. 
The mixed refrigerant cycle uses a single mixed refrigerant instead of multiple pure refrigerants as in the cascade cycle. The refrigerant is usually a mixture of nitrogen, methane, ethane, propane, butane, and pentane. Since it requires only one refrigerant compression cycle, its capital cost is relatively low. Theoretically, a single mixed refrigerant (SMR) cycle should provide sufficient refrigeration to cool $\mathrm{NG}$ to its boiling point at atmospheric pressure. In practice, however, a pre-cooling step is needed since the thermo-physical properties of the mixed refrigerant and machinery reduce efficiency. Thus, the NG feed is usually pre-cooled by a threestage propane refrigeration cycle $(\mathrm{C} 3 / \mathrm{MR})$ or by a separate mixed refrigeration cycle (dual mixed refrigerant (DMR) cycle).

The expander cycle uses an expansion turbine to expand the cycle gas in a near isentropic manner at an appropriate temperature, thereby reducing its temperature. The expansion generates useful work that is recovered through a booster compressor. A major disadvantage of this cycle is its relatively high power consumption compared to either the cascade or MR cycles. An expander cycle is, however, best suited to smaller plants with shorter operating periods because of its relatively rapid and simple start-up and shutdown.

NG liquefaction efficiency can be defined in terms of process efficiency or train efficiency, depending on the system boundary. Process efficiency, obtained from specific power, includes the power consumed by pre-cooling and liquefaction. Train efficiency is the total lower heating value (LHV) of valuable products (LNG and condensate) divided by the LHV of the feed (including energy for pre-cooling, liquefaction, power generation and utilities). Process efficiencies are documented in many published sources. Train efficiencies are less readily available. Values and sources of process and trail efficiencies are summarized in Table A-1.

TABLE A-1 Process and Train Efficiencies of Major NG Liquefaction Processes

\begin{tabular}{|c|c|c|c|c|c|}
\hline & $\mathrm{C} 3 / \mathrm{MR}$ & Cascade & DMR & SMR & Expande \\
\hline \multicolumn{6}{|c|}{ Specific Power (kWh/ton LNG) /Process Efficiency (\%) } \\
\hline Vink and Nagelvoort 1998 & 97.9 & 97.6 & 97.8 & 97.5 & 97.3 \\
\hline $\begin{array}{l}\text { Kikkawa and Nozawa } 1999 \\
\text { Brendeng and Hetland } 2004\end{array}$ & 97.6 & 96.6 & 97.9 & 97.5 & \\
\hline Finn et al. 1999 & 97.6 & 97.9 & & 97.4 & 96.5 \\
\hline Kikkawa and Liu 2001 & 98.0 & & & & \\
\hline Remeljej and Hoadley 2006 & & & & 97.5 & \\
\hline Average & 97.8 & 97.4 & 97.8 & 97.5 & 96.9 \\
\hline \multicolumn{6}{|l|}{ Train Efficiency $(\%)$} \\
\hline Vink and Nagelvoort 1998 & 90.7 & 89.0 & 90.5 & 89.4 & 88.2 \\
\hline Kikkawa and Aoki 1999 & 90 & & & & \\
\hline Kikkawa and Liu 2001 & & & & & \\
\hline
\end{tabular}


According to Brendeng and Hetland (2004), nearly 80\% of large-scale liquefaction units and almost $90 \%$ of global LNG-production capacity currently use C3/MR. However, it is not at all clear that $\mathrm{C} 3 / \mathrm{MR}$ is the best option for LFG-based liquefaction. Most of the sources reviewed for this effort indicate that SMR and expander cycles are good candidates for small-scale liquefaction. Moreover, for actual LFG-to-LNG projects, two current projects (Bowerman and Altamont) use SMR while a pilot project (Burlington) used a nitrogen expander.

GREET's default efficiency for large-scale liquefaction is $91 \%$. On average, SMR and expander cycles respectively take $14 \%$ and $40 \%$ more specific power than C3/MR. Assuming that $\mathrm{C} 3 / \mathrm{MR}$ represents large-scale liquefiers while SMR and expander cycles represent smallscale liquefiers and that the ratio between processing and train efficiencies remains constant, we estimate the average train efficiencies of SMR and expander cycles to be $89.9 \%$ and $87.8 \%$, respectively. These values compare well to the train efficiencies reported by Vink and Nagelvoort (1998). Using these data, GREET's small-scale liquefaction efficiency is set to $89 \%$. 


\section{APPENDIX B: CRITERIA POLLUTANTS}

Estimates of well-to-wheel (WTW), well-to-pump (WTP), and pump-to-wheel (PTW) criteria pollutant emissions for landfill gas (LFG) and fossil fuel-based pathways are shown in Figures B-1 through B-5. When PTW results are negative (e.g., CO emissions for pathways using grid electricity or $\mathrm{NO}_{\mathrm{x}}$ emissions for pathways using on-site power generation), the sum of WTP and PTW emissions is drawn as a darker shade of rose and is shown superimposed over its two components.

As shown in Figures B-1, B-2, and B-4, LFG-based pathways to CNG use in light-duty vehicles (LDVs) produce WTW CO, $\mathrm{NO}_{x}$, and $\mathrm{PM}_{2.5}$ emissions comparable to or less than those of fossil-based pathways to $\mathrm{CNG}$, NA NG, or petroleum gasoline. For heavy-duty vehicles (HDVs), WTW $\mathrm{NO}_{\mathrm{x}}$ and CO emissions of LFG-based LNG pathways are comparable to those of fossil-based pathways to NA NG or petroleum diesel. Because the U.S. generation mix is heavily weighted toward coal, displacing grid electricity with on-site power generation virtually eliminates $\mathrm{SO}_{\mathrm{x}}$ emissions (except for compression at the refueling station, which continues to use grid electricity) and results in major reductions in $\mathrm{NO}_{\mathrm{x}}$ and $\mathrm{PM}$ emissions. Since most on-site generators have lower $\mathrm{NO}_{\mathrm{x}}, \mathrm{PM}$, and $\mathrm{SO}_{\mathrm{x}}, \mathrm{PTW}$ emissions are shown as a credit or negative contribution to WTW results in Figures B-1 through B-5. For LNG-fueled vehicles, WTW PM 10 and $\mathrm{SO}_{\mathrm{x}}$ emissions are virtually zero.

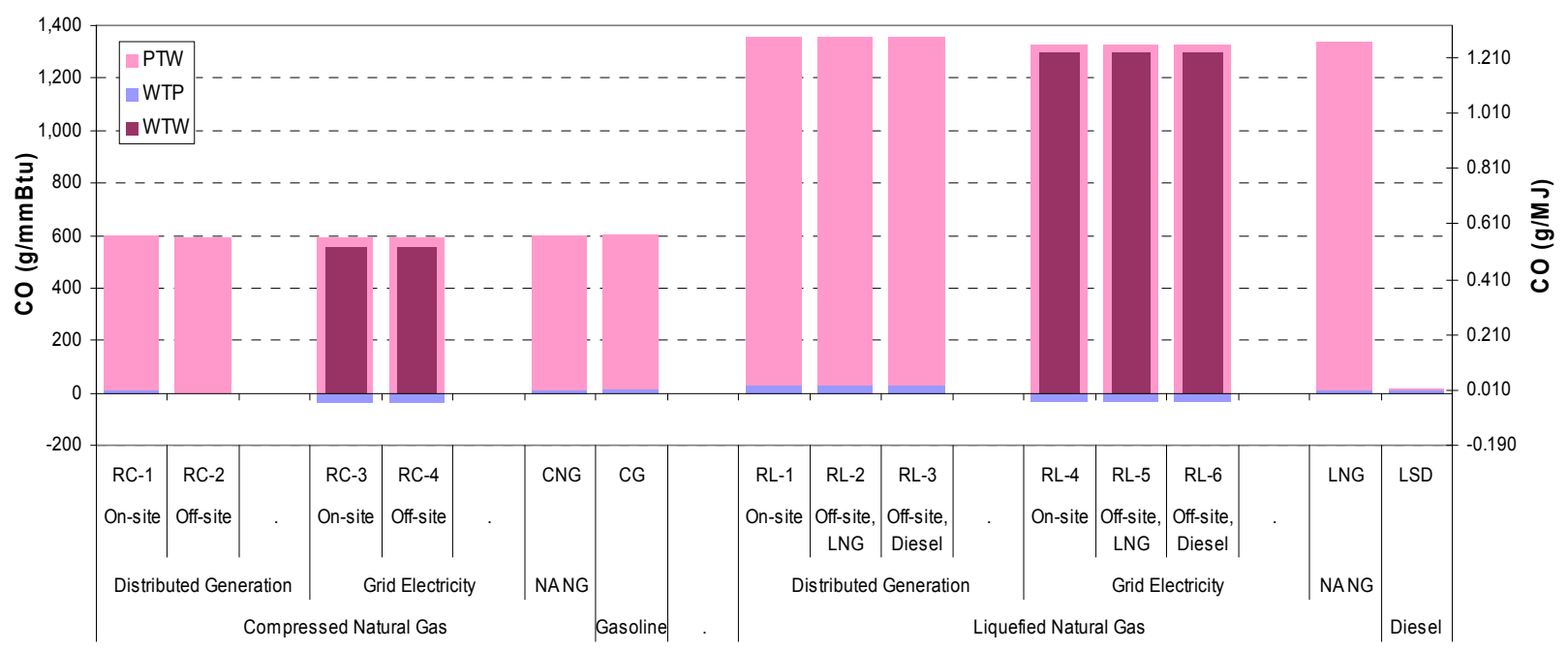

FIGURE B-1 CO Emissions for LFG-Based Pathways Compared with NA NG and Petroleum Gasoline and Diesel Pathways 


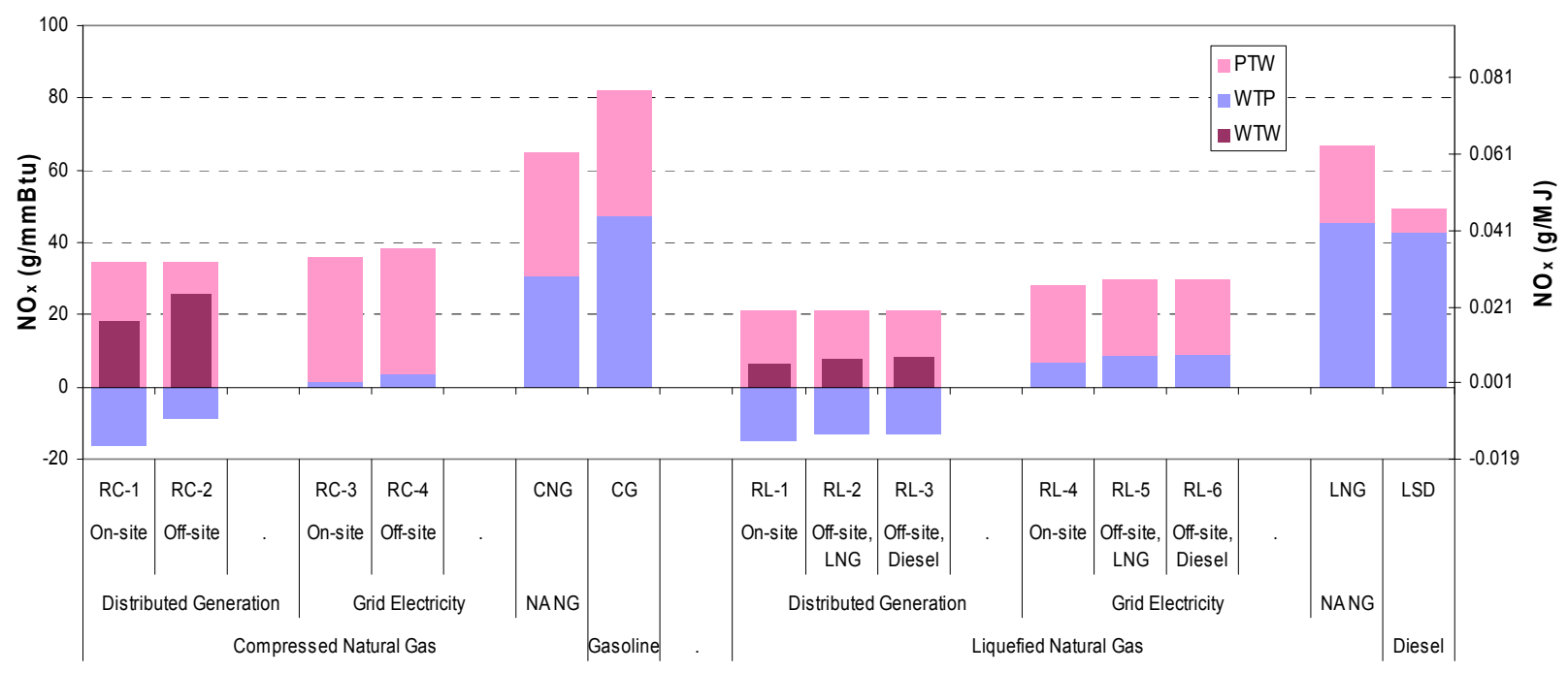

FIGURE B-2 NO $_{x}$ Emissions for LFG-Based Pathways Compared with NA NG and Petroleum Gasoline and Diesel Pathways

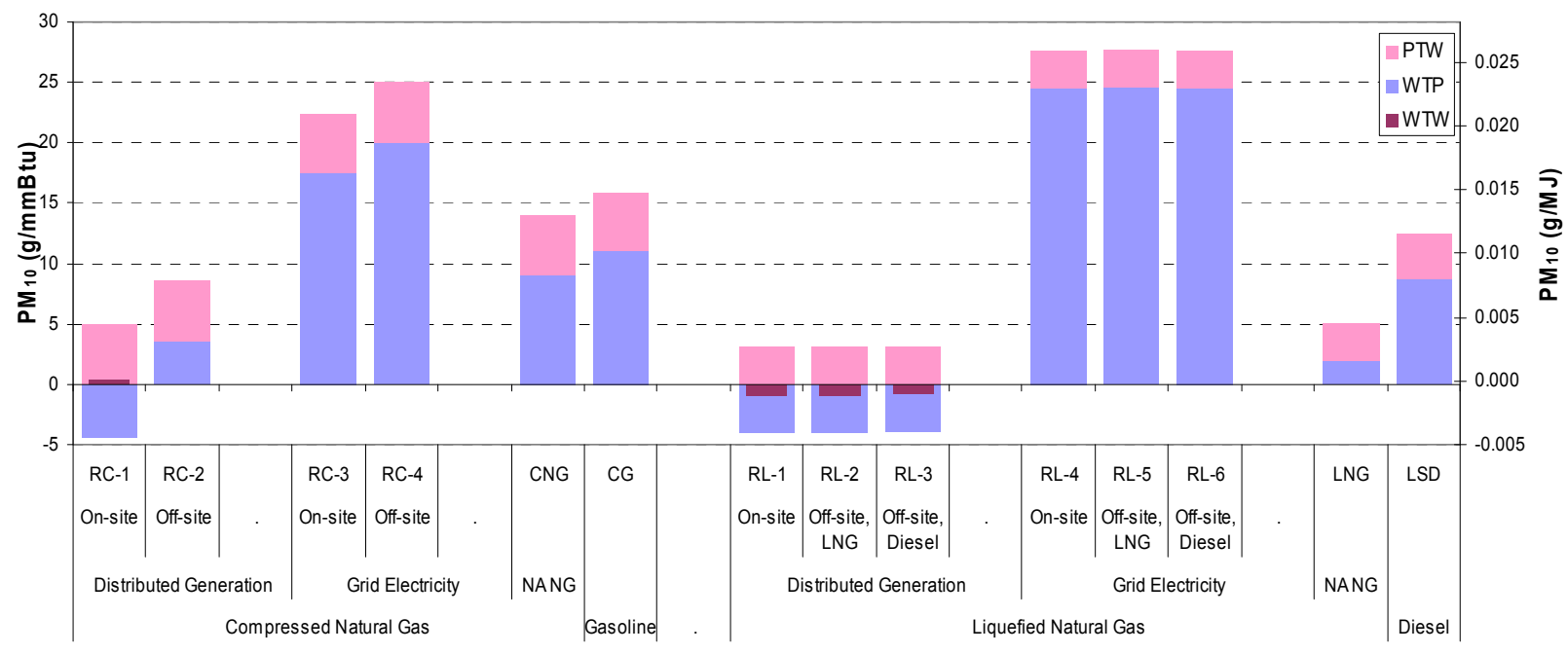

FIGURE B-3 PM PM $_{10}$ Emissions for LFG-Based Pathways Compared with NA NG and Petroleum Gasoline and Diesel Pathways 


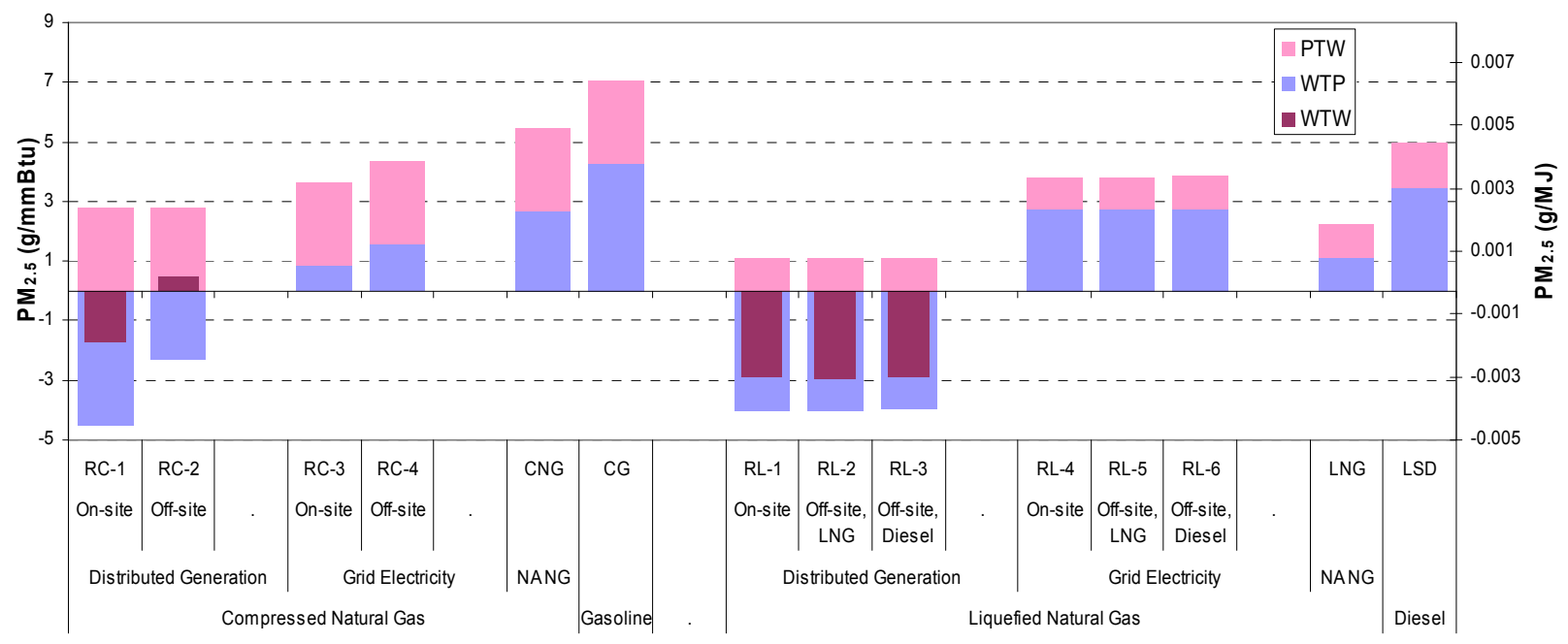

FIGURE B-4 PM PM.5 $_{2.5}$ Emissions for LFG-Based Pathways Compared with NA NG and Petroleum Gasoline and Diesel Pathways

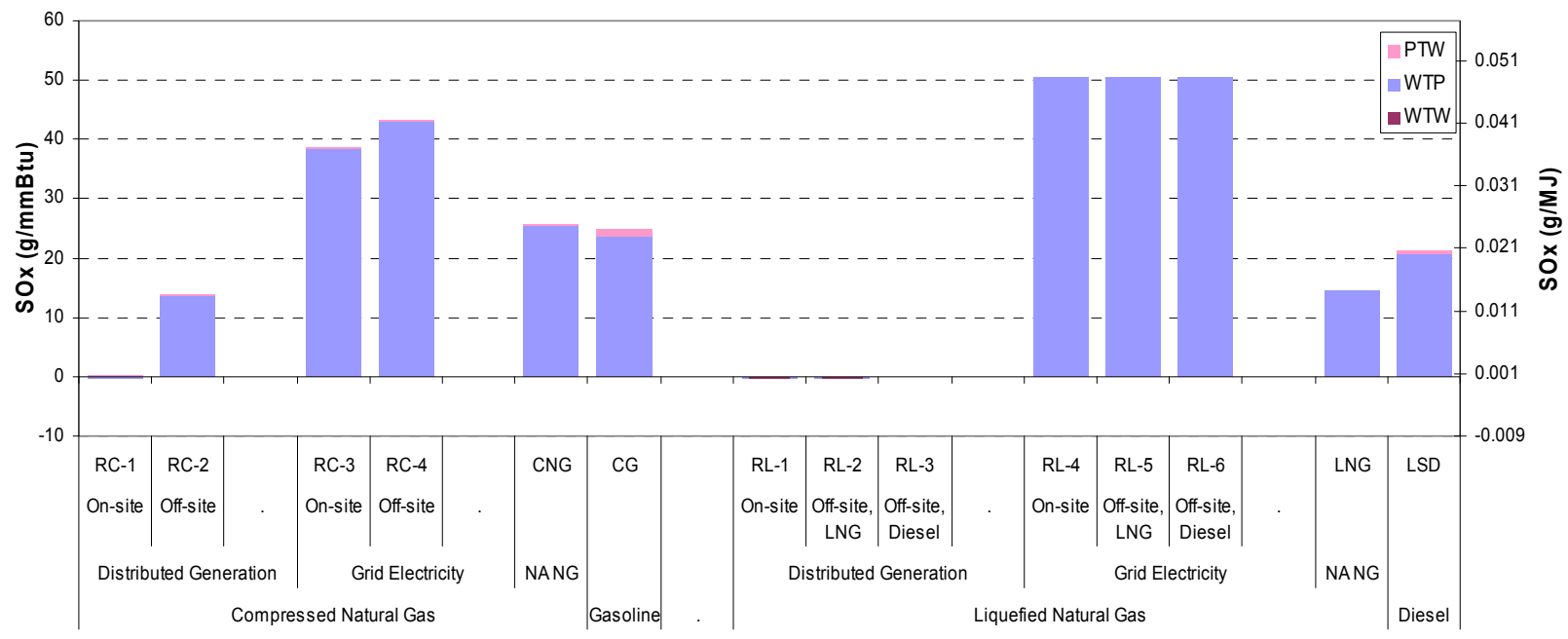

FIGURE B-5 SO $_{x}$ Emissions for LFG-Based Pathways Compared with NA NG and Petroleum Gasoline and Diesel Pathways 
Argonne

Energy Systems Division

Argonne National Laboratory

9700 South Cass Avenue, Bldg. 362

Argonne, IL 60439-4815

www.anl.gov

U.S. DEPARTMENT OF

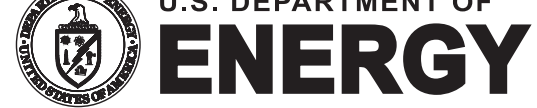

Argonne National Laboratory is a U.S. Department of Energy

laboratory managed by UChicago Argonne, LLC 